US Army Corps of Engineers ${ }_{\circledast}$

Engineer Research and Development Center

Desktop Study for La Quinta Project; Shoaling Prediction in La Quinta Navigation Channel and Effect of a Barrier on Siltation in Extended La Quinta Channel

Trimbak M. Parchure, Soraya Sarruff, and Ben Brown

September 2002 
The contents of this report are not to be used for advertising, publication, or promotional purposes. Citation of trade names does not constitute an official endorsement or approval of the use of such commercial products.

The findings of this report are not to be construed as an official Department of the Army position, unless so designated by other authorized documents. 


\section{Desktop Study for La Quinta Project; Shoaling Prediction in La Quinta Navigation Channel and Effect of a Barrier on Siltation in Extended La Quinta Channel}

by Trimbak M. Parchure, Soraya Sarruff, Ben Brown

Coastal and Hydraulics Laboratory

U.S. Army Engineer Research and Development Center 3909 Halls Ferry Road

Vicksburg, MS 39180-6199

Final report

Approved for public release; distribution is unlimited 


\section{Contents}

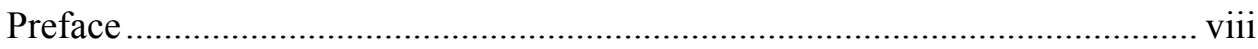

Conversion Factors, Non-SI to SI Units of Measurement................................ ix

1-Shoaling Prediction in La Quinta Navigation Channel ............................... 1

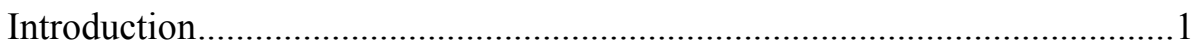

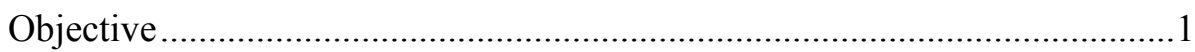

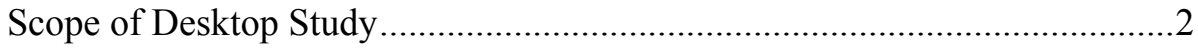

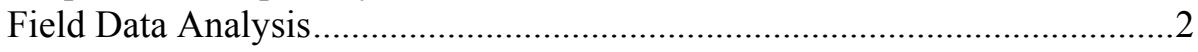

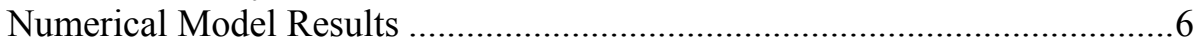

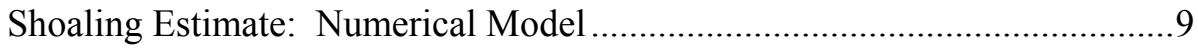

Shoaling Estimate: Analytical Methods....................................................

Shoaling Estimate: Empirical Methods.....................................................10

Shoaling Estimate: Dredging Data Method ..............................................10

Discussion of Parameters .......................................................................... 10

Relative change in length, depth, and width .......................................10

Properties of bed material...................................................................... 11

Geometry of the navigation channel ...................................................11

Properties of suspended material .............................................................11

Magnitude of suspended sediment concentration.....................................11

Change in the magnitude and direction of current conditions..................11

Wind and wave climate at the site .........................................................12

Nature and location of sediment source ...............................................12

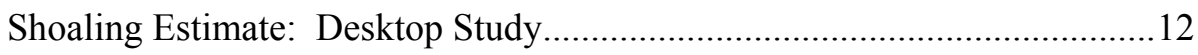

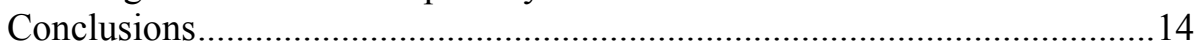

2-Effect of a Barrier on Siltation in Extended La Quinta Channel....................33

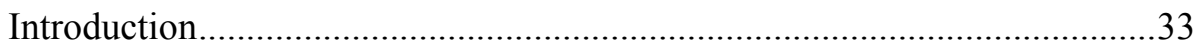

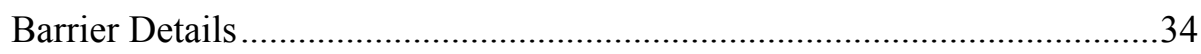

Numerical Model Results ................................................................. 35

Discussion of Flow Pattern ..................................................................... 36

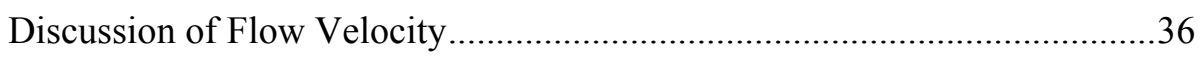

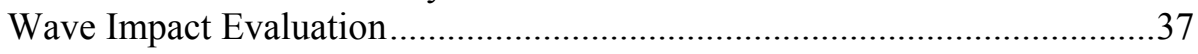

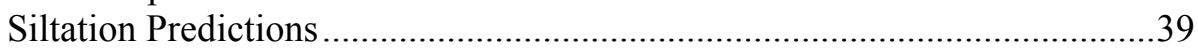

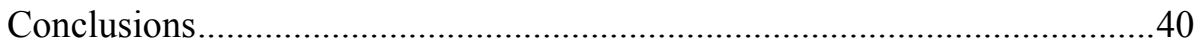


SF 298

\section{List of Figures}

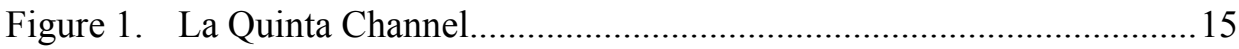

Figure 2. Locations of collection of sediment and water samples ...................16

Figure 3. La Quinta channel reaches and zones..........................................17

Figure 4. La Quinta channel dredging quantities during 1982 ...................... 18

Figure 5. La Quinta channel dredging quantities during 1985 ....................... 19

Figure 6. La Quinta channel dredging quantities during 1987 ......................20

Figure 7. La Quinta channel dredging quantities during $1991 \ldots \ldots \ldots \ldots \ldots \ldots \ldots \ldots . . .21$

Figure 8. La Quinta channel dredging quantities during 1996 ......................22

Figure 9. Grid used for numerical model..................................................23

Figure 10. June tides and southeast wind selected for model run.....................24

Figure 11. October tides and north wind selected for model run......................25

Figure 12. Locations of velocity gages in numerical model ............................26

Figure 13. Flow pattern for the base condition, June tide, ebb, no wind ...........22

Figure 14. Flow pattern for the base condition, June tide, flood, no wind ........28

Figure 15. Flow pattern for the plan condition, October tide, ebb, no wind......29

Figure 16. Flow pattern for the plan condition, October tide, flood, no wind...30

Figure 17. Flow pattern for the plan condition, June tide, ebb, no wind ............31

Figure 18. Flow pattern for the plan condition, June tide, flood, no wind .........32

Figure 19. Location map of study area ......................................................... 41

Figure 20. Layout of the present La Quinta ship channel.................................42

Figure 21. Layout of La Quinta navigation channel ........................................ 43

Figure 22. Layout of segmented barrier proposal ..........................................44 
Figure 23. Cross-sectional view of segmented barrier proposal

Figure 24. Grid used for numerical model...................................................... 46

Figure 25. La Quinta navigation channel, base condition ...............................47

Figure 26. La Quinta navigation channel, Plan 1 condition with continuous barrier

Figure 27. La Quinta navigation channel, Plan 2 condition with continuous barrier.

Figure 28. June tides and southeast wind selected for model run......................50

Figure 29. Locations of velocity stations in numerical model...........................51

Figure 30. Numerical model flow pattern for base condition, flood..................52

Figure 31. Numerical model flow pattern for base condition, ebb ...................52

Figure 32. Numerical model flow pattern for Plan 1, flood...............................53

Figure 33. Numerical model flow pattern for Plan 1, ebb ...............................53

Figure 34. Numerical model flow pattern for Plan 2, flood.............................54

Figure 35. Numerical model flow pattern for Plan 2, ebb ..............................54

Figure 36. Velocity at station 1 obtained on numerical model ..........................55

Figure 37. Velocity at station 2 obtained on numerical model .........................55

Figure 38. Velocity at station 3 obtained on numerical model .........................56

Figure 39. Velocity at station 4 obtained on numerical model ..........................56

Figure 40. Velocity at station 5 obtained on numerical model .........................57

Figure 41. Velocity at station 6 obtained on numerical model ........................57

Figure 42. Velocity at station 7 obtained on numerical model .........................58

Figure 43 . Velocity at station 8 obtained on numerical model .........................58

Figure 44. Velocity at station 9 obtained on numerical model .........................59

Figure 45 . Velocity at station 10 obtained on numerical model .......................59

Figure 46. Velocity at station 11 obtained on numerical model .......................60

Figure 47. Velocity at station 12 obtained on numerical model .......................60 
Figure 48. Velocity at station 13 obtained on numerical model 61

Figure 49. Velocity at station 14 obtained on numerical model .......................61

Figure 50. Velocity at station 15 obtained on numerical model .......................62

Figure 51. Velocity at station 16 obtained on numerical model .......................62

Figure 52. Velocity at station 17 obtained on numerical model ......................63

Figure 53. Velocity at station 18 obtained on numerical model ........................63

Figure 54. Velocity at station 19 obtained on numerical model .......................64

Figure 55. Velocity at station 20 obtained on numerical model .......................64

Figure 56. Velocity at station 21 obtained on numerical model .......................65

Figure 57. Velocity at station 22 obtained on numerical model .......................65

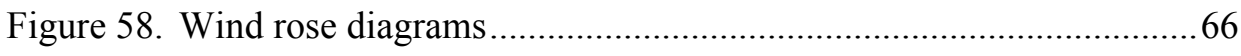

Figure 59. La Quinta channel reaches and zones...........................................67

\section{List of Tables}

Table 1. Results of Analysis of Surface Bed Samples.....................................2

Table 2. Results of Water Sample Analysis for the La Quinta

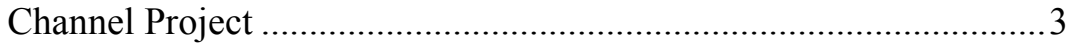

Table 3. La Quinta Channel Dredging History ..............................................

Table 4. La Quinta Channel Reaches Relative to the Reference Stations Used By the Galveston District ........................................................5

Table 5. La Quinta Channel Dredging History ............................................ 6

Table 6. Conditions Used for Running Numerical Model...............................

Table 7. Maximum Velocity Obtained on Numerical Model at

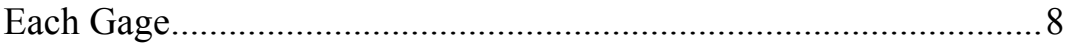

Table 8. La Quinta Channel Estimated Dredging Quantities .........................13

Table 9. Comparison of Maximum Velocities Observed on the Numerical Model. .37 
Table 10. Estimated Wave Heights for Given Wind Conditions ......................38

Table 11. Estimated Bed Velocity and Bed Shear Stress for

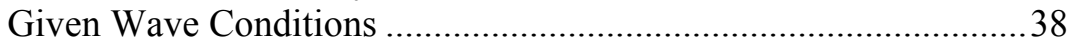




\section{Preface}

The U.S. Army Engineer District, Galveston, proposed two projects for the navigation channel at La Quinta, TX. The first was related to extension of the navigation channel at its northern end, and the second consisted of construction of a barrier on the south side of the extended channel. A desktop study was conducted at the Coastal and Hydraulics Laboratory (CHL) of the U.S. Army Engineer Research and Development Center (ERDC), Vicksburg, MS, during 2000-2001 for estimation of siltation in the navigation channel resulting from each of these two projects. The Galveston District provided funding for this study. Dr. Trimbak M. Parchure, CHL, was the principal investigator for the project. Dr. Parchure prepared this report jointly with Ms. Soraya Sarruff and Mr. Ben Brown of CHL. Mr. Ed Reindl and Ms. Nancy Young of Galveston District supplied the data available at the District. The CHL field data collection team, consisting of Mr. Tim Fagerburg, Mr. John Bull, and Mr. Chris Callegan, collected new field data. Mr. Doug Brister of CHL conducted laboratory analysis of bed samples and water samples under the guidance of Dr. Allen Teeter.

The work was conducted under general supervision of Dr. Robert $\mathrm{T}$. McAdory, Chief, Estuarine Engineering Branch, CHL. Mr. Thomas W. Richardson was Director, CHL.

At the time of publication of this report, Dr. James R. Houston was Director of ERDC, and COL John W. Morris III, EN, was Commander and Executive Director.

The contents of this report are not to be used for advertising, publication or promotional purposes. Citation of trade names does not constitute an official endorsement or approval of the use of such commercial products. 


\section{Conversion Factors, Non-SI to SI Units of Measurement}

Non-SI units of measurement used in this report can be converted to SI units as follows:

\begin{tabular}{|l|l|l|}
\hline \hline Multiply & By & To Obtain \\
\hline \hline cubic yards & 0.7645549 & cubic meters \\
\hline feet & 0.3048 & meters \\
\hline miles (U.S. statute) & 1.609347 & kilometers \\
\hline \hline
\end{tabular}




\section{Shoaling Prediction in La Quinta Navigation Channel}

\section{Introduction}

The La Quinta navigation channel is located in Corpus Christi Bay, Texas. The Corpus Christi ship channel runs east-west, whereas the La Quinta channel runs approximately in the north-south direction. The northern end terminates in a turning circle, whereas the southern end is connected to the Corpus Christi ship channel. The U.S. Army Engineer District, Galveston, is considering deepening and extension of the La Quinta navigation channel with the following options:

a. Extension of the existing channel with a new turning basin at the end of the extension.

b. Deepening the existing channel to $50 \mathrm{ft}^{1}$ without extension.

c. Extension of the channel and deepening the entire channel to $50 \mathrm{ft}$.

The District requested the Coastal and Hydraulics Laboratory (CHL) of the U.S. Army Engineer Research and Development Center (ERDC), Vicksburg, MS, conduct a desktop study for estimation of future shoaling in the extended La Quinta ship channel for the first option given above.

\section{Objective}

The objective of the desktop study was to estimate the shoaling rate in the La Quinta channel resulting from extension of the existing channel.

The Galveston District had requested that ERDC-CHL conduct a ship simulator study and modify the layout of the navigation channel if necessary for ease of navigation. These studies are complete, and a modified layout has been submitted to the District. The desktop study adopted the modified layout shown in Figure 1 for estimation of shoaling.

\footnotetext{
${ }^{1}$ A table of factors for converting SI units of measurement is presented on page ix.
} 


\section{Scope of Desktop Study}

At this stage the Galveston District needed an approximate answer requiring less time and cost. Hence, the following approach and scope of work were adopted for a desktop study:

a. Field data already available as well as those collected by CHL were analyzed, and the results of analysis will be used.

$b$. Assumptions were made on the spatial and temporal variation in the values of relevant parameters.

c. Runs were conducted on the existing numerical hydrodynamic model for a few selected conditions to determine the effect of deepening the channel on the currents in the area of interest.

d. A quantitative estimate was provided on future shoaling in the navigation channel based on the field and model data analysis.

\section{Field Data Analysis}

The Galveston District supplied survey data, dredging history, and project layout maps, which have been used for the present study.

CHL collected 6 surface bed sediment samples and 21 mid-depth water samples within the La Quinta ship channel. These were analyzed at the CHL Sedimentation Laboratory to determine particle-size distribution. Locations of all the water and bed samples are shown in Figure 2. Results of bed sample analysis are given in Table 1. It can be seen that the sediment predominantly consists of a mixture of silt and clay with about 45 percent clay and 45 to 50 percent silt.

\section{Table 1}

Results of Analysis of Surface Bed Samples

\begin{tabular}{||l|l|l|l||}
\hline \hline Sample No. & $\mathbf{D}_{\mathbf{5 0}, \mu}$ & $\begin{array}{l}\text { Percent less than } \\
\mathbf{4} \mu \text { (clay) }\end{array}$ & $\begin{array}{l}\text { Percent less than } \\
\mathbf{6 4} \boldsymbol{\mu} \text { (silt + clay) }\end{array}$ \\
\hline \hline 40 & 4.76 & 45 & 94 \\
\hline 44 & 5.47 & 41 & 85 \\
\hline 48 & 4.90 & 44 & 95 \\
\hline 52 & 4.91 & 45 & 85 \\
\hline 55 & 4.91 & 44 & 90 \\
\hline 57 & 5.38 & 42 & 91 \\
\hline
\end{tabular}

The water samples were analyzed to determine the concentration of total suspended matter (TSM) and salinity. The results are given in Table 2. Channel reaches are defined in Figure 3. It can be seen that salinity varied from 38.26 to $38.71 \mathrm{ppt}$. This range is higher than normal ocean salinity, which is close to $35 \mathrm{ppt}$. The reason for higher salinity is low rainfall during the preceding year. 


\begin{tabular}{|c|c|c|c|c|c|c|c|}
\hline \multicolumn{8}{|c|}{$\begin{array}{l}\text { Table } 2 \\
\text { Results }\end{array}$} \\
\hline \multirow{2}{*}{\begin{tabular}{|l} 
Channel \\
Zone
\end{tabular}} & \multirow[b]{2}{*}{ Reach No. } & \multirow{2}{*}{$\begin{array}{l}\text { Location } \\
\text { No. }\end{array}$} & \multicolumn{2}{|c|}{ Sampling } & \multirow[b]{2}{*}{ Depth, ft } & \multirow{2}{*}{$\begin{array}{l}\text { Conc. } \\
\mathrm{mg} / \mathrm{l}\end{array}$} & \multirow{2}{*}{$\begin{array}{l}\text { Salinity } \\
\text { Ppt }\end{array}$} \\
\hline & & & Date & Time & & & \\
\hline $\mathrm{A}$ & 37 & 38 & $8 / 15 / 99$ & 1618 & 21.5 & 11 & 38.41 \\
\hline$B$ & 36 & 39 & $"$ & 1625 & 22.0 & 9 & 38.32 \\
\hline \multirow[t]{5}{*}{ C } & 35 & 40 & $"$ & 1629 & 24.3 & 11 & 38.35 \\
\hline & 35 & 41 & " & 1635 & 24.5 & 11 & 38.32 \\
\hline & 34 & 42 & $"$ & 1640 & 23.5 & 5 & 38.30 \\
\hline & 33 & 43 & $"$ & 1647 & 24.0 & 7 & 38.39 \\
\hline & 33 & 44 & $"$ & 1653 & 24.5 & 7 & 38.26 \\
\hline \multirow[t]{4}{*}{$D$} & 32 & 45 & $"$ & 1659 & 24.5 & 8 & 38.26 \\
\hline & 31 & 46 & $"$ & 1705 & 25.0 & 9 & 38.57 \\
\hline & 31 & 47 & $"$ & 1712 & 23.8 & 12 & 38.62 \\
\hline & 30 & 48 & $"$ & 1718 & 25.0 & 9 & 38.64 \\
\hline \multirow[t]{5}{*}{$\mathrm{E}$} & 29 & 49 & $"$ & 1724 & 24.0 & 8 & 38.64 \\
\hline & 29 & 50 & $"$ & 1729 & 24.5 & 9 & 38.65 \\
\hline & 28 & 51 & $"$ & 1736 & 24.5 & 9 & 38.69 \\
\hline & 27 & 52 & $"$ & 1742 & 25.5 & 10 & 38.69 \\
\hline & 27 & 53 & $"$ & 1749 & 25.5 & 10 & 38.68 \\
\hline \multirow[t]{2}{*}{$\mathrm{F}$} & 24 & 54 & $"$ & 1756 & 24.0 & 14 & 38.71 \\
\hline & 22 & 55 & $"$ & 1803 & 25.0 & 4 & 38.66 \\
\hline \multirow[t]{3}{*}{$G$} & 19 & 56 & $"$ & 1811 & 24.5 & 5 & 38.53 \\
\hline & 17 & 57 & $"$ & 1819 & 24.0 & 3 & 38.55 \\
\hline & 14 & 58 & $"$ & 1827 & 23.5 & 8 & 38.61 \\
\hline
\end{tabular}

Past data have indicated that salinity of Corpus Christi Bay is sensitive to local freshwater inputs or deficits. The narrow band of variation indicates close to uniform salinity along the navigation channel.

TSM varied from $3 \mathrm{mg} / 1$ to $12 \mathrm{mg} / \mathrm{l}$, which is quite low. However, it may be noted that field data were collected during calm weather conditions. Suspended sediment concentration could be much higher during adverse conditions such as high wind and wave conditions. Values of TSM are within a narrow band of variation, indicating close to uniform conditions along the navigation channel.

Dredging records of La Quinta channel supplied by the Galveston District are given in Table 3. It may be noted that the District has provided the average dredging quantity of $371,064 \mathrm{cu}$ yd/year, which was obtained by dividing the total dredging, carried out over the 20 -year period 1979 - 1998. Hence, in the absence of any specific clarification and any other dredging data, the quantities listed in Table 3 are considered to be maintenance dredging quantities. The quantities given in Table 3 are the crucial data for annual shoaling estimates made in this report. If these quantities also include capital dredging, the estimated shoaling quantities will have to be worked out again based on the maintenance dredging alone.

Table 3 also gives rounded dredging intervals as 4,7 and 10 years for different reaches of the navigation channel. Such large intervals result in a very economical dredging operation. These intervals could be achieved by overdredging to allow sufficient margin below navigable depth for annual siltation to occur and by conducting dredging operations only when needed. 


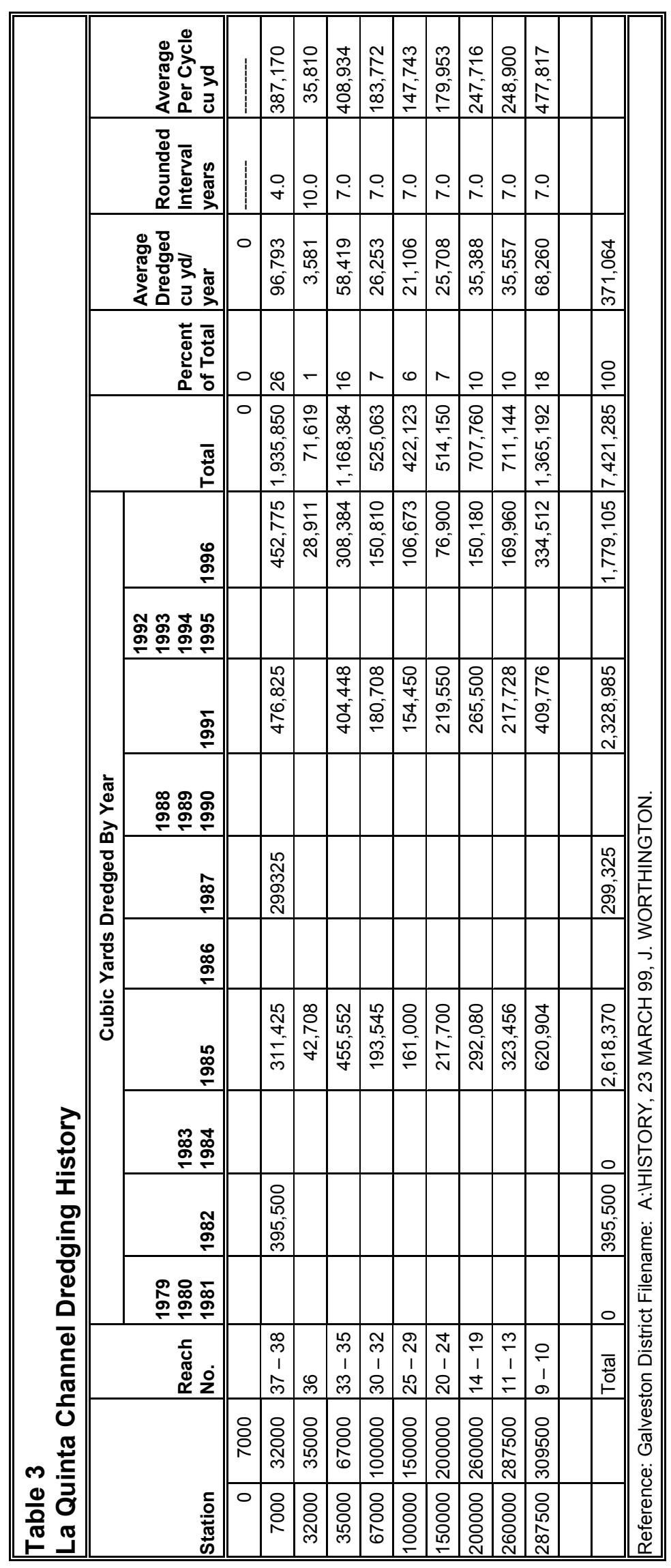


The Galveston District uses stations to denote reference to locations along the channel. For convenience of the present study, the channel was divided into reaches, each about 1,000 ft long. The reaches were given numbers beginning with 1 at the farthest end of the new turning basin, and ending with 38 at the point of intersection of the centerlines of the La Quinta and Corpus Christi navigation channels. The reaches are grouped into 11 zones labeled A through $\mathrm{K}$. Table 4 gives definitions of La Quinta channel reaches and zones relative to the reference stations used by the Galveston District. The zones and reaches are also shown in Figure 3.

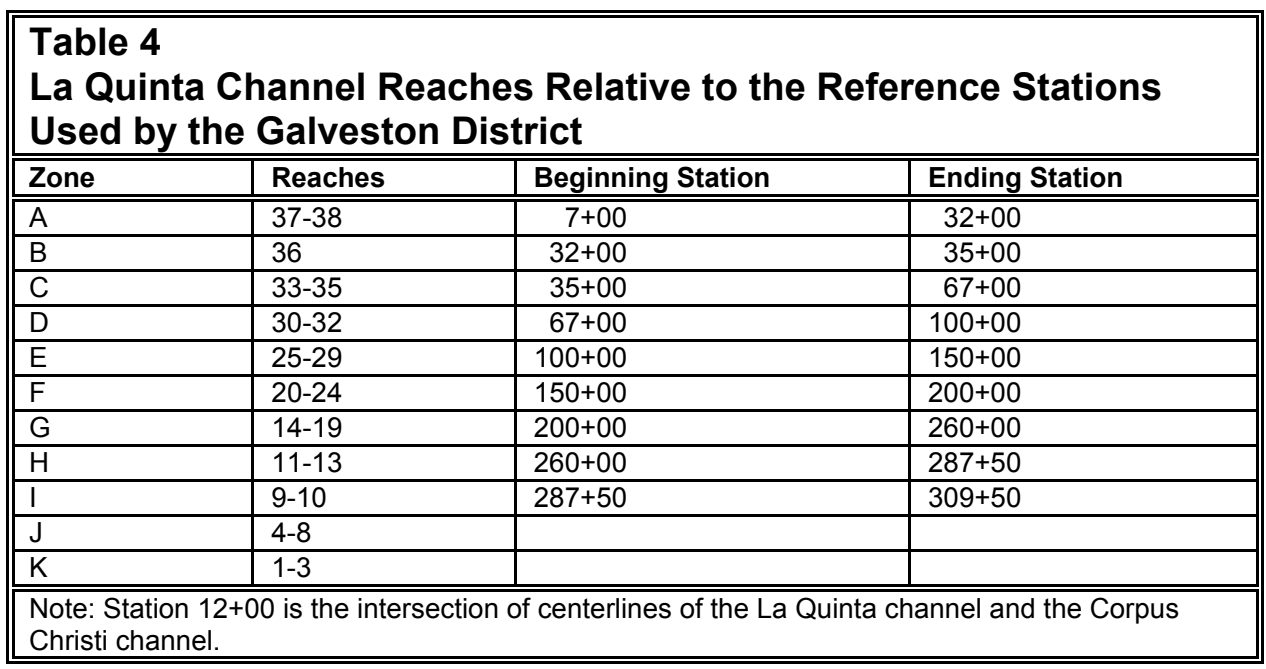

The Galveston District supplied dredging records to CHL for the years 1979 to 1996. Since no dredging has been reported until the end of 1998, the data are assumed to cover a 20-year period from 1979 to 1998 . Dividing the total quantity of sediment dredged by 20 gives the average dredging quantity at $371,064 \mathrm{cu} y d / y e a r$. Table 5 is a modified format of Table 3 . It includes only those years during which dredging was conducted, provides dredging quantities over 11 zones of the La Quinta channel, and also provides percentage of dredging in each zone. It is noted that zones A, B, C, and I make up 61 percent of the dredging. Figures 4-8 show the quantity of sediment removed from each reach of the channel for the years 1982, 1985, 1987, 1991, and 1996, respectively.

The Corpus Christi navigation channel is located within Galveston Bay in close vicinity of the La Quinta navigation channel. Field data on several parameters such as tides, wind, bed sediment, suspended sediment, and dredging records were obtained by CHL from three sources: data supplied by Galveston District, field data collected by CHL, and data from other sources. Although dredging records and sediment characteristics are very much site-specific, data on tides and wind are applicable over the general area. Results of analysis and conclusions are given in Parchure, Sarruff, and Brown (2001). 


\section{Table 5 \\ La Quinta Channel Dredging History}

\begin{tabular}{|c|c|c|c|c|c|c|c|c|c|c|c|}
\hline \multicolumn{12}{|c|}{ Cubic Yards Dredged by Year } \\
\hline \multicolumn{2}{|c|}{ Stations } & \multirow{2}{*}{ 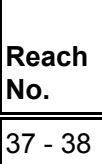 } & \multirow{2}{*}{\begin{tabular}{|l} 
Zone \\
A
\end{tabular}} & \multirow{2}{*}{$\frac{1982}{395,500}$} & \multirow{2}{*}{$\begin{array}{l}1985 \\
311,425\end{array}$} & \multirow{2}{*}{$\begin{array}{l}1987 \\
299,325\end{array}$} & \multirow{2}{*}{$\begin{array}{l}1991 \\
476,825\end{array}$} & \multirow{2}{*}{$\begin{array}{l}1996 \\
452,775\end{array}$} & \multirow{2}{*}{\begin{tabular}{|l} 
Total \\
$1,935,850$
\end{tabular}} & \multirow{2}{*}{$\frac{\begin{array}{l}\text { Percent } \\
\text { of Total }\end{array}}{}$} & \multirow{2}{*}{\begin{tabular}{|l|}
$\begin{array}{l}\text { Average } \\
\text { Dredged } \\
\text { cu yd/year }\end{array}$ \\
96,793 \\
\end{tabular}} \\
\hline 7000 & 32000 & & & & & & & & & & \\
\hline 32000 & 35000 & 36 & B & & 42,708 & & & 28,911 & 71,619 & 1 & 3,581 \\
\hline 35000 & 67000 & $33-35$ & C & & 455,552 & & 404,448 & 308,384 & $1,168,384$ & 16 & 58,419 \\
\hline 67000 & 100000 & $30-32$ & D & & 193,545 & & 180,708 & 150,810 & 525,063 & 7 & 26,253 \\
\hline 100000 & 150000 & $25-29$ & E & & 161,000 & & 154,450 & 106,673 & 422,123 & 6 & 21,106 \\
\hline 150000 & 200000 & $20-24$ & $\mathrm{~F}$ & & 217,700 & & 219,550 & 76,900 & 514,150 & 7 & 25,708 \\
\hline 200000 & 260000 & $14-19$ & $G$ & & 292,080 & & 265,500 & 150,180 & 707,760 & 10 & 35,388 \\
\hline 260000 & 287500 & $11-13$ & $\mathrm{H}$ & & 323,456 & & 217,728 & 169,960 & 711,144 & 10 & 35,557 \\
\hline \multirow[t]{4}{*}{287500} & 309500 & $9-10$ & I & & 620,904 & & 409,776 & 334,512 & $1,365,192$ & 18 & 68,260 \\
\hline & & $4-8$ & $\mathrm{~J}$ & & & & & & & & \\
\hline & & $1-3$ & K & & & & & & & & \\
\hline & & Total & & 395,500 & $2,618,370$ & 299,325 & $2,328,985$ & $1,779,105$ & $7,421,285$ & 100 & 371,064 \\
\hline
\end{tabular}

Quantities in this column are obtained by dividing the total quantity by 20 years (1979 to 1998). No dredging was done during the years $1979-1981$ and 1997-1998.

\section{Numerical Model Results}

A vertically averaged, two-dimensional numerical model of the area was already available at CHL. The area included in the model as well as the model grids are shown in Figure 9. This model was previously used for the Texas Water Development Board for conducting a salinity study of the Corpus Christi Bay and surrounding area. Modifications were made to this model for increasing resolution within the navigation channel and other areas. Proposed extension of the channel and the new turning basin were incorporated. The model was validated earlier. ${ }^{1}$ Revalidation of the model specifically for the La Quinta area was not done because it was not covered under the present scope of work. Hence, the model results are likely to be approximate.

It was clear from the site conditions that tides and winds have a strong combined seasonal frequency of occurrence. Data on both these parameters were analyzed for selecting appropriate combination of the two parameters. Conditions selected for running the numerical model are shown in Figures 10 and 11. Data analysis indicated that the June tides are associated with southeast winds, whereas October tides are associated with the north wind.

The "base condition" in the model consisted of 1999 bathymetry with the navigation channel at a 45-ft depth. Data on flow pattern and current velocity were obtained by running the model without and with wind. The model was then

\footnotetext{
${ }^{1}$ T. M. Smith, W. H. McAnally, and A. M. Teeter. (2000). "Validation of hydrodynamic model," Memorandum for Record, CEERD-HE-TE (1110-2-1403b), July 20, 2000.
} 
run for the "plan condition" by simulating the extended navigation channel and the new turning basin dredged to a $45-\mathrm{ft}$ depth. Minor modification in terms of local widening of the La Quinta channel for ease of navigation as recommended by CHL was also incorporated. Conditions used for running the numerical model are given in Table 6 .

\begin{tabular}{|c|c|c|c|}
\hline \multicolumn{4}{|c|}{$\begin{array}{l}\text { Table } 6 \\
\text { Conditions Used for Running Numerical Model }\end{array}$} \\
\hline Condition No. & Bathymetry & Tide & "Wind \\
\hline$\overline{11}$ & Base & June tide & No wind \\
\hline 2 & Base & June tide & Southeast wind \\
\hline 3 & Base & October tide & No wind \\
\hline 4 & Base & October tide & North wind \\
\hline 5 & Plan & June tide & No wind \\
\hline 6 & Plan & October tide & No wind \\
\hline
\end{tabular}

Velocity data from the model were obtained at 12 sections across the navigation channel. Each section had three gages, one in the middle of the channel, one on the north side, and one on the south side of the channel, thus making 36 gage locations. Locations of gages are shown in Figure 12. The model was run for equivalent field duration of 5 days. Allowing time for initial spinup and stabilization, model data from $69.0 \mathrm{hr}$ to $96.5 \mathrm{hr}$ were extracted for analysis.

Representative flow patterns obtained from the model for the flood and ebb stages of tide are shown in Figures 13-18. Maximum velocities at each gage for the base and plan conditions are listed in Table 7.

The following observations are made from the velocity data:

a. The maximum current velocity along the channel for the October tide, no wind condition, zones D through I, increased by about 30 to 40 percent as a result of channel extension. The increased velocities are within 0.1 and $0.2 \mathrm{ft} / \mathrm{s}$. The increase in velocities in zones A through $\mathrm{C}$ was less than 20 percent.

b. The maximum current velocity along the channel for the June tide, no wind condition, zones D through I, increased by about 40 to 60 percent as a result of channel extension. The increased velocities are within 0.1 and $0.3 \mathrm{ft} / \mathrm{s}$. The increase in velocities in zones $A$ through $C$ was less than 20 percent.

c. North wind caused about a 50-percent increase in channel current velocity for October tide, whereas southeast wind nearly doubled the June tidal current velocity in the channel. This is because the southeast wind generally has a higher magnitude over longer duration than the north wind. 


\begin{tabular}{|c|c|c|c|c|c|c|c|c|}
\hline \multicolumn{9}{|c|}{$\begin{array}{l}\text { Table } 7 \\
\text { Maximum Velocity (ft/s) Obtained on Numerical Model at Each Gage }\end{array}$} \\
\hline Zone & Section & Gage & $\begin{array}{l}\text { Base, } \\
\text { No wind, } \\
\text { October Tide }\end{array}$ & \begin{tabular}{|l} 
Base, \\
No wind, \\
June Tide
\end{tabular} & \begin{tabular}{|l} 
Base, \\
North wind, \\
October Tide
\end{tabular} & $\begin{array}{l}\text { Base, } \\
\text { SE wind, } \\
\text { June Tide }\end{array}$ & $\begin{array}{l}\text { Plan, } \\
\text { No wind, } \\
\text { October Tide }\end{array}$ & \begin{tabular}{|l} 
Plan, \\
No wind, \\
June Tide
\end{tabular} \\
\hline \multirow[t]{3}{*}{ K } & 2 & 130 & 0.0497741 & 0.0451487 & 0.152394 & 0.210688 & 0.0410299 & 0.0440859 \\
\hline & 2 & 131 & 0.0627979 & 0.0604337 & 0.154829 & 0.214136 & 0.0418303 & 0.0459171 \\
\hline & 2 & 132 & 0.0805257 & 0.0841378 & 0.150923 & 0.204477 & 0.041276 & 0.0471831 \\
\hline \multirow[t]{3}{*}{$J$} & 6 & 133 & 0.244224 & 0.253171 & 0.365994 & 0.401481 & 0.0982575 & 0.115672 \\
\hline & 6 & 134 & 0.270258 & 0.292447 & 0.406246 & 0.489011 & 0.0940256 & 0.109333 \\
\hline & 6 & 135 & 0.225558 & 0.245183 & 0.335905 & 0.461319 & 0.0924396 & 0.102448 \\
\hline \multirow[t]{3}{*}{ I } & 9 & 136 & 0.0825356 & 0.0868893 & 0.129379 & 0.416153 & 0.0913829 & 0.0989169 \\
\hline & 9 & 137 & 0.0603167 & 0.0605614 & 0.0879882 & 0.132189 & 0.0859021 & 0.096673 \\
\hline & 9 & 138 & 0.0555419 & 0.0528609 & 0.069824 & 0.103637 & 0.0768792 & 0.0847529 \\
\hline \multirow[t]{3}{*}{$\mathrm{H}$} & 12 & 139 & 0.0859268 & 0.0863681 & 0.141332 & 0.143701 & 0.125169 & 0.140819 \\
\hline & 12 & 140 & 0.0890402 & 0.089386 & 0.125875 & 0.237759 & 0.129516 & 0.145515 \\
\hline & 12 & 141 & 0.0885856 & 0.0865643 & 0.134128 & 0.126374 & 0.124347 & 0.135526 \\
\hline \multirow[t]{6}{*}{$G$} & 15 & 142 & 0.0770193 & 0.0775259 & 0.105024 & 0.159678 & 0.110377 & 0.123271 \\
\hline & 15 & 143 & 0.0827804 & 0.083061 & 0.124991 & 0.232847 & 0.119643 & 0.134101 \\
\hline & 15 & 144 & 0.0867018 & 0.0857557 & 0.127546 & 0.169652 & 0.123275 & 0.136967 \\
\hline & 18 & 145 & 0.154865 & 0.153019 & 0.208998 & 0.219457 & 0.219662 & 0.240356 \\
\hline & 18 & 146 & 0.1411 & 0.141672 & 0.210549 & 0.316029 & 0.20496 & 0.230371 \\
\hline & 18 & 147 & 0.0761988 & 0.0760535 & 0.107524 & 0.141895 & 0.118603 & 0.123717 \\
\hline \multirow[t]{6}{*}{$\mathrm{F}$} & 21 & 148 & 0.102406 & 0.100402 & 0.143692 & 0.120153 & 0.141798 & 0.153886 \\
\hline & 21 & 149 & 0.11143 & 0.111643 & 0.17125 & 0.282576 & 0.159129 & 0.178388 \\
\hline & 21 & 150 & 0.101113 & 0.100522 & 0.128316 & 0.170948 & 0.142675 & 0.157431 \\
\hline & 24 & 151 & 0.0711838 & 0.0710428 & 0.0979285 & 0.243001 & 0.100203 & 0.111396 \\
\hline & 24 & 152 & 0.075492 & 0.0757299 & 0.127552 & 0.285255 & 0.107273 & 0.120191 \\
\hline & 24 & 153 & 0.0764479 & 0.0762056 & 0.125842 & 0.256965 & 0.107293 & 0.119295 \\
\hline \multirow[t]{3}{*}{$E$} & 27 & 154 & 0.0768465 & 0.0766013 & 0.104335 & 0.215011 & 0.102141 & 0.112695 \\
\hline & 27 & 155 & 0.0766083 & 0.0771177 & 0.17022 & 0.3275 & 0.104954 & 0.119043 \\
\hline & 27 & 156 & 0.0730947 & 0.0704941 & 0.153284 & 0.180387 & 0.0889605 & 0.0965431 \\
\hline \multirow[t]{3}{*}{$\bar{D}$} & 30 & 157 & 0.144637 & 0.133849 & 0.156992 & 0.197898 & 0.174055 & 0.174201 \\
\hline & 30 & 158 & 0.207581 & 0.202981 & 0.301194 & 0.296005 & 0.26658 & 0.288168 \\
\hline & 30 & 159 & 0.253722 & 0.2548 & 0.421131 & 0.531456 & 0.33533 & 0.376573 \\
\hline \multirow[t]{3}{*}{ C } & 33 & 160 & 0.141086 & 0.127996 & 0.144707 & 0.220565 & 0.163209 & 0.161925 \\
\hline & 33 & 161 & 0.224689 & 0.221121 & 0.316973 & 0.373762 & 0.264001 & 0.279436 \\
\hline & 33 & 162 & 0.29401 & 0.301771 & 0.379161 & 0.291359 & 0.304332 & 0.314929 \\
\hline \multirow[t]{3}{*}{ B } & 36 & 163 & 0.441171 & 0.446613 & 0.46523 & 0.605561 & 0.463798 & 0.475106 \\
\hline & 36 & 164 & 0.573627 & 0.600213 & 0.659943 & 0.567269 & 0.603508 & 0.634909 \\
\hline & 36 & 165 & 0.778113 & 0.854376 & 0.864987 & 0.698002 & 0.80873 & 0.882618 \\
\hline
\end{tabular}




\section{Shoaling Estimate: Numerical Model}

The best way to estimate changes in siltation rates in navigation channels is the application of a verified sediment transport and shoaling/erosion numerical model. The prerequisite for a numerical sediment model consists of a verified hydrodynamic model of the area and appropriate field sediment data for verification of the sediment model. Numerical models are recommended particularly for systems such as La Quinta, which involve new construction. The choice of a two-dimensional or three-dimensional model is based upon the extent of vertical variation of parameters such as salinity, velocity, and suspended sediment concentration and the significance of these parameters for the study in hand. Selection of a sediment model out of the various available models is based upon the type of sediment, predominant modes of transport, and site conditions. A large number of studies involving sediment problems have been conducted all over the world using numerical sediment models. These are reported in publications such as the proceedings of the Fifth International Conference on Estuarine and Coastal Modeling (Spaulding and Blumberg 1997). Most of the numerical sediment models are expensive and time-consuming.

\section{Shoaling Estimate: Analytical Methods}

A general approach for an analytical method consists of using carefully selected formulas for calculating the values of required quantity. The criteria for selection of formulas are based upon their applicability at the given site and the problem. The formulas may contain several fluid-related and sediment-related parameters. The value of each parameter may be determined by means of field or laboratory studies or from literature and provided as input in the formulas for obtaining the answer. Several sediment transport formulas and methods are available for cohesive and noncohesive sediments; bed load, suspended load, and total load; currents and waves; bank erosion, bed erosion, and cliff erosion; incipient motion and turbulent convection; etc. Methods are available from a simple formula given by DuBoys (1879) to the complex bed load function given by Einstein (1950). The relationship between sediment discharge and flow velocity may be quite complex. The sediment discharge rate may be proportional to the flow velocity to the power of anywhere from 2 to 6 . Hence, the answer will vary by several orders of magnitude depending upon the power used. Formulas are also available for sediment erosion and deposition. If selected carefully and applied properly, these methods sometimes provide order of magnitude estimates of sediment erosion/deposition transport.

Such formulas or methods that may be universally applicable are not available in books or published literature for estimating change in siltation rates in navigation channels as a result of extension, widening, or deepening. 


\section{Shoaling Estimate: Empirical Methods}

Empirical methods are not based upon any established theory. Laboratory or field data are collected on certain preselected parameters, and empirical relationships are established using statistical/curve-fitting techniques. These methods are often too simplistic and less reliable and are not always approved by the technical communities. However, they sometimes serve the site-specific purpose very well. Examples of such methods in the field of sediment transport are the century-old regime theory formulas developed for design of irrigation canals, some of which are still applicable. Such empirical methods are not available for application to sediment problems of navigation channels.

\section{Shoaling Estimate: Dredging Data Method}

An increase in length, width, or depth of a navigation channel often results in an increased quantity of siltation and hence an increased cost/frequency of dredging. Data on dredging quantities before and after deepening and/or widening are very useful in prediction of future quantities. For instance, if a navigation channel was deepened from $35 \mathrm{ft}$ to $40 \mathrm{ft}$ and dredging records were available for the predeepening and postdeepening conditions, they could be analyzed and used for predicting the effect of further deepening to say $45 \mathrm{ft}$. Such types of data are not available for the La Quinta project. The Port of Corpus Christi navigation channel is located in the vicinity of the La Quinta channel. This channel was deepened from $40 \mathrm{ft}$ to $45 \mathrm{ft}$ around 1985 . Unfortunately, reliable predredging and postdredging records are not available. Even if such records were available, they would not have been applicable because the Corpus Christi and La Quinta channels have an entirely different geometry and geographical configurations. Hence, the dredging data method cannot be used for the La Quinta project.

\section{Discussion of Parameters}

\section{Relative change in length, depth, and width}

An increase in channel length and width increases its plan area. Since the dredged navigation channels are typically below the surrounding bed, they act as a sediment trap. Hence, an increase in plan area (length and width) increases the sediment deposition quantity. A change in channel depth almost invariably results in increased sediment deposition because a deeper channel acts as a more efficient sediment trap. If the channel is very shallow compared to the surrounding area, the trapping efficiency is small, and a considerable quantity of sediment may bypass over the channel. Sediment in suspension requires a certain amount of time to fall through the water column to reach the natural or dredged bed elevation. During this process it is also being carried in the direction of flow. Hence, a sediment particle at the water surface takes a trajectory path during its travel from the surface to the bed. If the channel is wide enough, the particle will deposit within the channel; otherwise, it will bypass. 


\section{Properties of bed material}

Noncohesive and cohesive sediments have widely varying properties governing their erosion, transport, and deposition. Mixtures of these two types of sediment prevail at most sites. Hence, the equations and methods used for determining these characteristics are also different. Appropriate selection of equations and methods needs to be made, depending upon the sediment present at the site.

\section{Geometry of the navigation channel}

Alignment of the channel relative to currents is important. Currents crossing the channel width cause more sediment deposition than currents flowing along a channel. The sedimentation pattern is also different for open channels versus channels with natural protection.

\section{Properties of suspended material}

Noncohesive sediment such as sand has a larger particle size (on the order of millimeters) and a higher weight. When these particles are suspended, they tend to deposit quickly as soon as the fluid-induced force that keeps them in suspension drops below the critical value for deposition. This time may be on the order of a few minutes to hours. On the other hand, fine sediments have a small size (on the order of microns), which keeps them in suspension for a much longer time, on the order of weeks or even months. Organic substances in suspension have a low specific weight and an open structure. Hence, they remain in suspension longer, on the order of several days, unless they flocculate with other inorganic substances.

\section{Magnitude of suspended sediment concentration}

The noncohesive sediment particles settle independently through the water column. Their fall velocity is a function of parameters such as shape factor, density, and particle size. The fine sediment particles flocculate and settle as flocs. The fall velocity of flocs is a complex function of suspended sediment concentration, which varies over water depth.

\section{Change in the magnitude and direction of current conditions}

Modification to channel geometry or channel dimensions may result in change in the magnitude and direction of currents. These changes have a profound influence on sediment deposition. Currents across the width of a channel will deposit more sediment than currents along the channel. 


\section{Wind and wave climate at the site}

Wind and waves induce shear on the water surface, which may extend through the water column all the way to the bed and influence sediment transport or resuspension.

\section{Nature and location of sediment source}

The local bed may be a source for sediment convection or the sediment may be reaching the area of interest from an outside source. An assessment of sediment source helps in predictions.

\section{Shoaling Estimate: Desktop Study}

A desktop study is conducted when application of the methods described above is not possible for one reason or another. An accepted practice consists of applying a multiplication factor greater than 1.0 to the dredging quantities for the predeepening and prewidening conditions. Several parameters are taken into account while selecting this factor, which is very much site-specific and may vary for different locations of the same project. Such a desktop study has severe limitations for want of adequate data, tools, or methods available for predicting anticipated future dredging quantities. The estimates are made based on experience, field data, and an understanding of site conditions. The study provides an order of magnitude estimates, which may be used for budgeting purposes, for working out an approximate benefit-to-cost ratio, etc.

Extension of the La Quinta channel represents new dredging. Hence, data on siltation over the proposed reach of extension are not available. This limitation lowers the degree of confidence in siltation prediction. Dredging records of the present La Quinta channel supplied by the Galveston District have been the most important data for shoaling prediction.

Field data show that the bottom sediment in the La Quinta channel consists of mostly fine sediment in the categories of silt and clay. It may be assumed that the shoaling is caused by deposition of suspended sediment and not through bed load transport. It may be noted that only six surface bed samples were available along the length of the channel, which may or may not be representative of the entire channel. The conclusion will have to be revised if the site conditions are different from those assumed here.

Currents play an important role in transporting the sediment in suspension, which gets deposited over an area where the sediment carrying capacity of currents falls below a threshold. This will happen in the area where the existing ground will be dredged for providing a 45 -ft-deep channel extension and a new turning basin.

The sediment deposits on the southwest side of La Quinta channel provide considerable protection to the major length of navigation channel. These 
deposits have probably resulted from dumping of dredged material during earlier years. The channel extension as well as the new turning basin will be beyond the natural protection offered by these deposits. The extended channel and turning basin will be fully exposed to the cross-currents, wind, and waves generated over long fetch. Hence, shoaling in the newly dredged areas will be much higher than in the sheltered areas. The present La Quinta channel is about $300 \mathrm{ft}$ wide and 5.5 miles long. The proposed channel extension including the turning basin is about 1.42 miles long with varying widths greater than $300 \mathrm{ft}$. Larger size of the new turning basin and greater width of the extended channel will also result in higher volumes of siltation than in the corresponding present channel areas.

The currents within the existing channel are mostly along the channel length, confined by the local geometry, and the current strength is relatively low. Over the area of channel extension, the currents are at an angle to the channel orientation. This configuration would cause enhanced siltation in the dredged areas.

These factors have been taken into account while selecting the shoaling increase factors given in Table 8. Estimated dredging quantities per year are also given in Table 8 for different reaches of the existing and extended La Quinta channel. It is estimated that the annual dredging in the portion of the present La Quinta channel will increase from $371,000 \mathrm{cu}$ yd to $428,000 \mathrm{cu}$ yd. It is also estimated that the annual dredging in the extended channel and the new turning basin will be $127,000 \mathrm{cu}$ yd. Thus, the total annual dredging after project implementation is estimated to be on the order of $650,000 \mathrm{cu}$ yd.

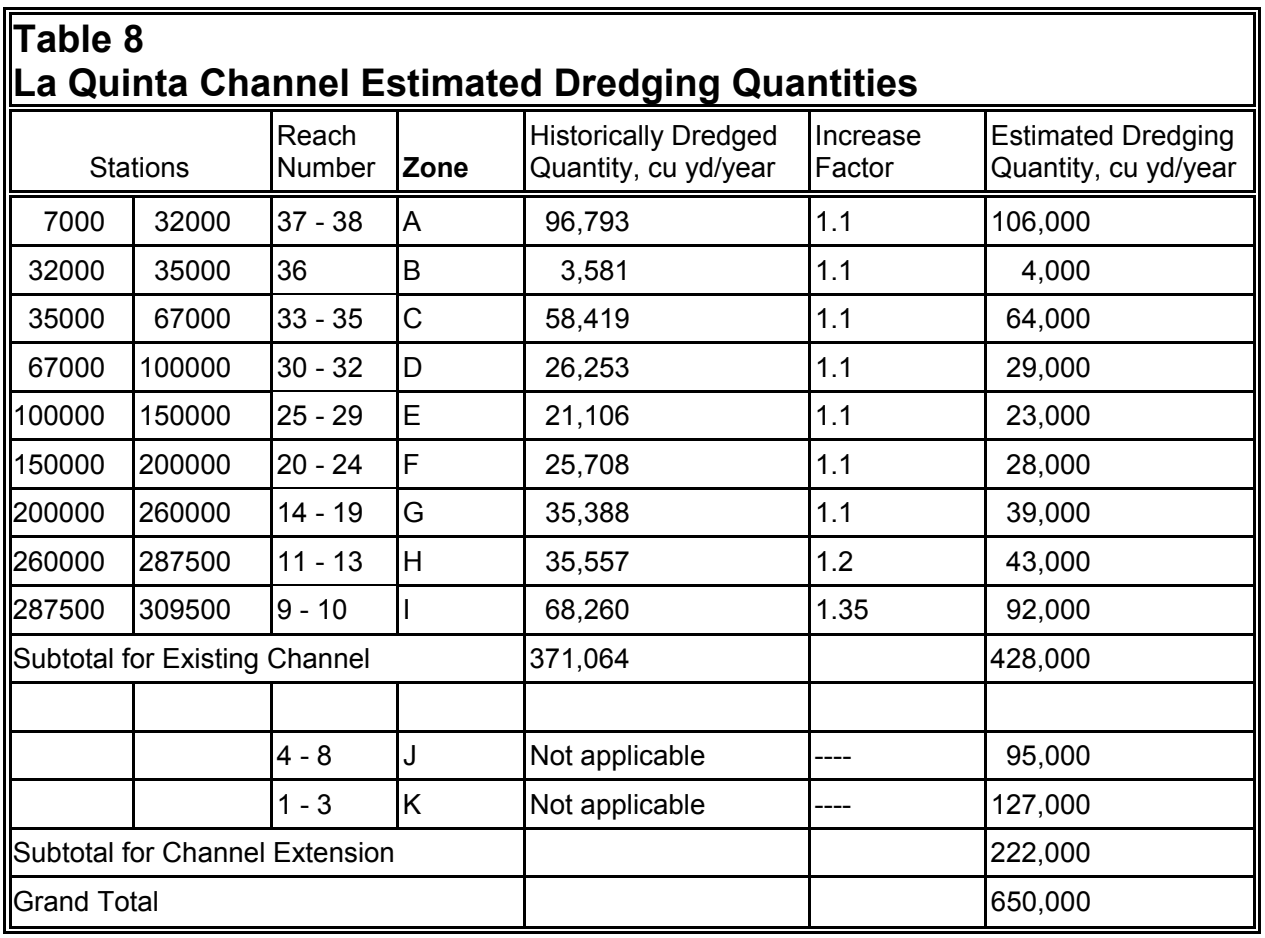




\section{Conclusions}

The following conclusions may be drawn:

a. Proposed extension of the La Quinta navigation channel and provision of a new turning basin, both dredged to a 45 -ft-depth, will cause an increase in the present tidal currents. This increased current is expected to increase the inflow of sediment in the channel and hence result in increased shoaling.

b. The bed sediment in the La Quinta channel consists of mostly fine sediment in the categories of silt and clay. This composition suggests that the major process of shoaling consists of frequent deposition of suspended sediment.

c. The area of channel extension and new turning basin has currents at an angle to the channel alignment. This configuration increases the probability of deposition of suspended sediment in the area. The new turning basin is larger than the existing basin, and the extended channel is wider than the existing channel. These factors contribute to the higher siltation in these reaches.

d. The estimated dredging quantities per year based on several considerations described earlier are given below.

\begin{tabular}{||l|l|l||}
\hline & $\begin{array}{l}\text { Present dredging } \\
\text { cu yd/year }\end{array}$ & $\begin{array}{l}\text { Estimated dredging after } \\
\text { channel extension and new } \\
\text { turning basin, cu yd/year }\end{array}$ \\
\hline \hline Existing channel & 371,064 & 428,000 \\
\hline $\begin{array}{l}\text { Channel extension and } \\
\text { new turning basin }\end{array}$ & ------- & 222,000 \\
\hline \multicolumn{1}{|c|}{ Total } & 371,064 & 650,000 \\
\hline
\end{tabular}

e. It is assumed in this study that the existing turning basin will be maintained at its present configuration. If it has no use after creation of the new turning basin, only the channel component of that area will require maintenance, thus resulting in considerable savings in local dredging cost. 


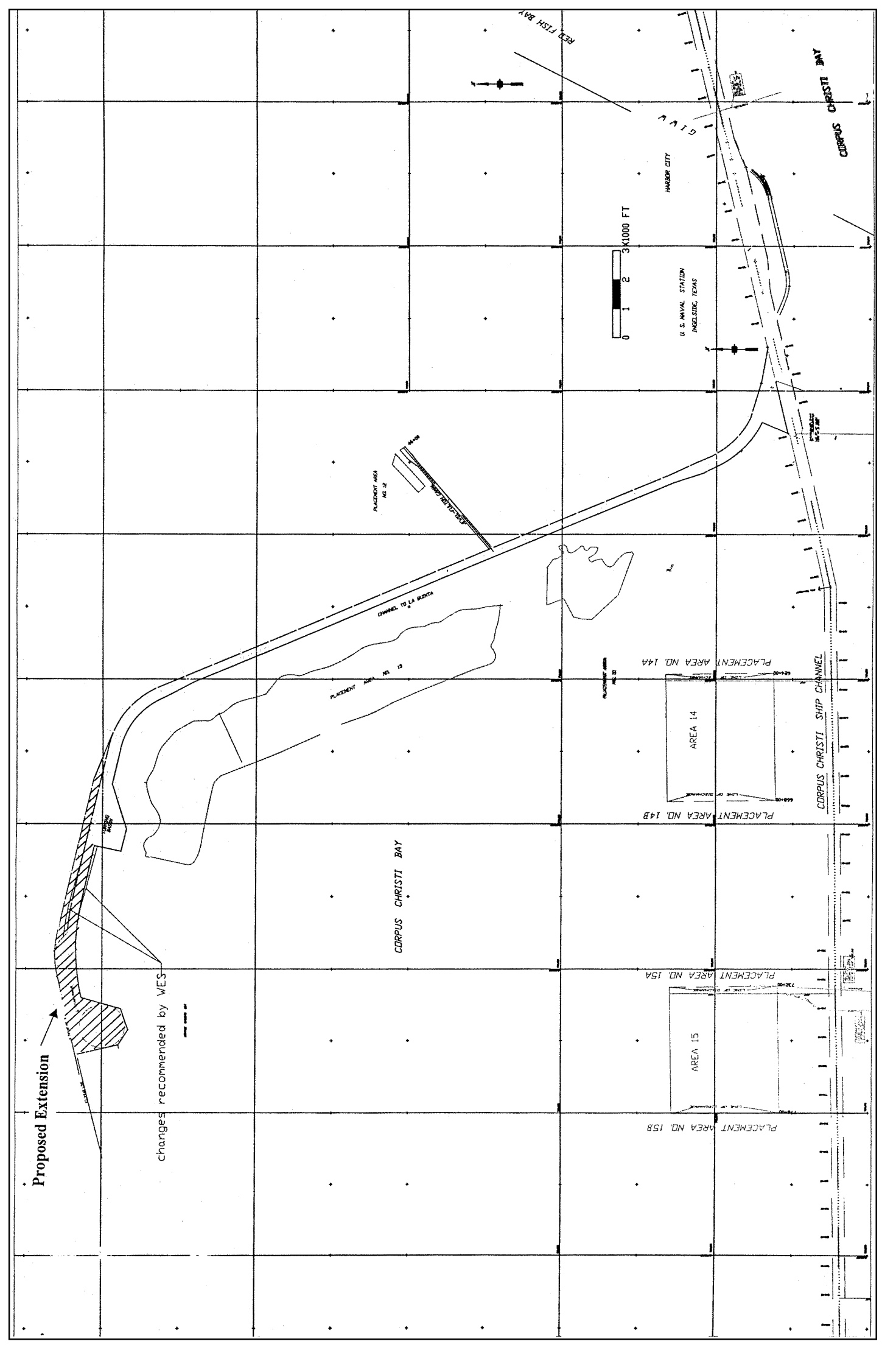

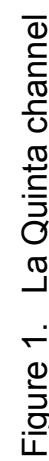




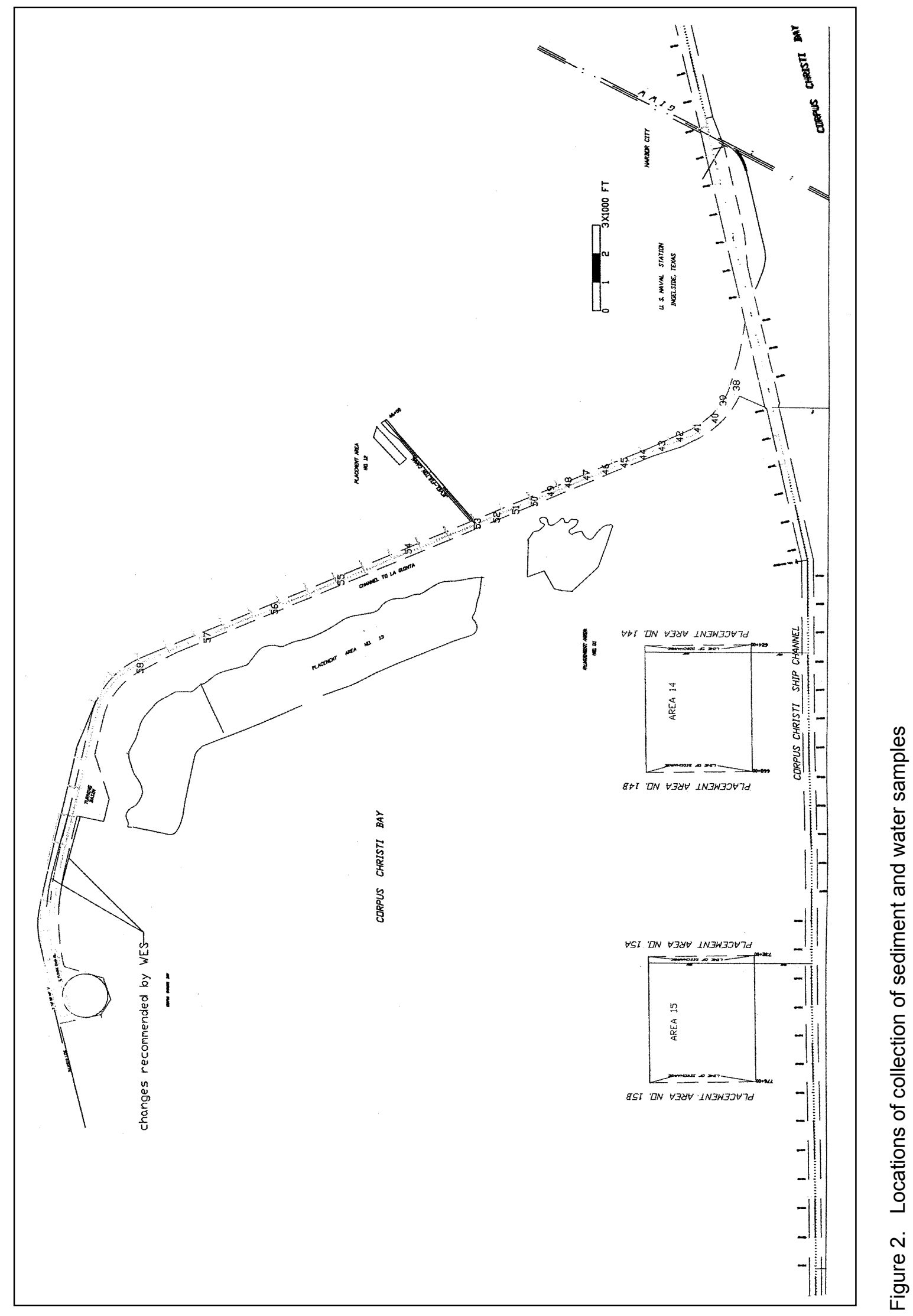




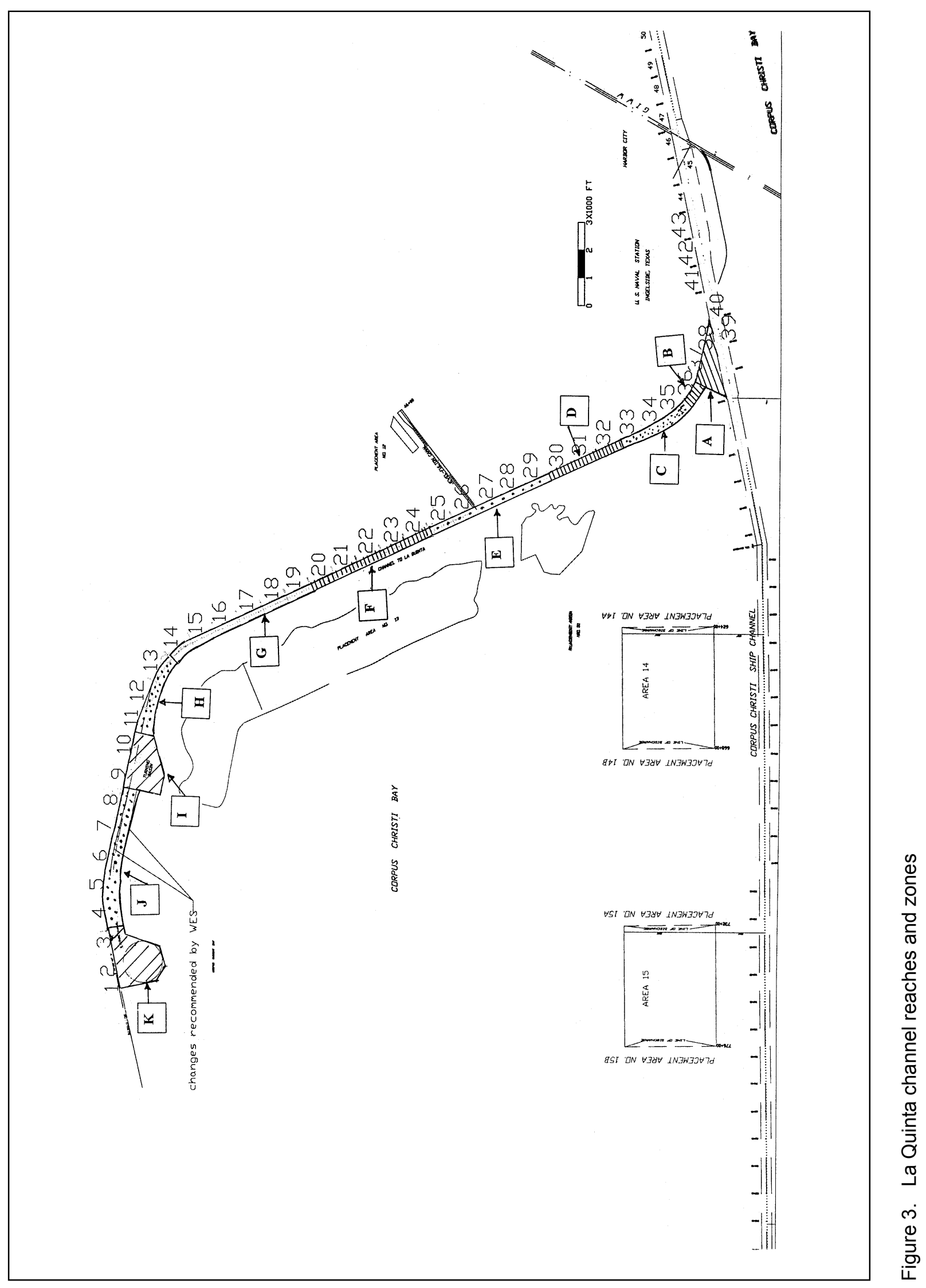




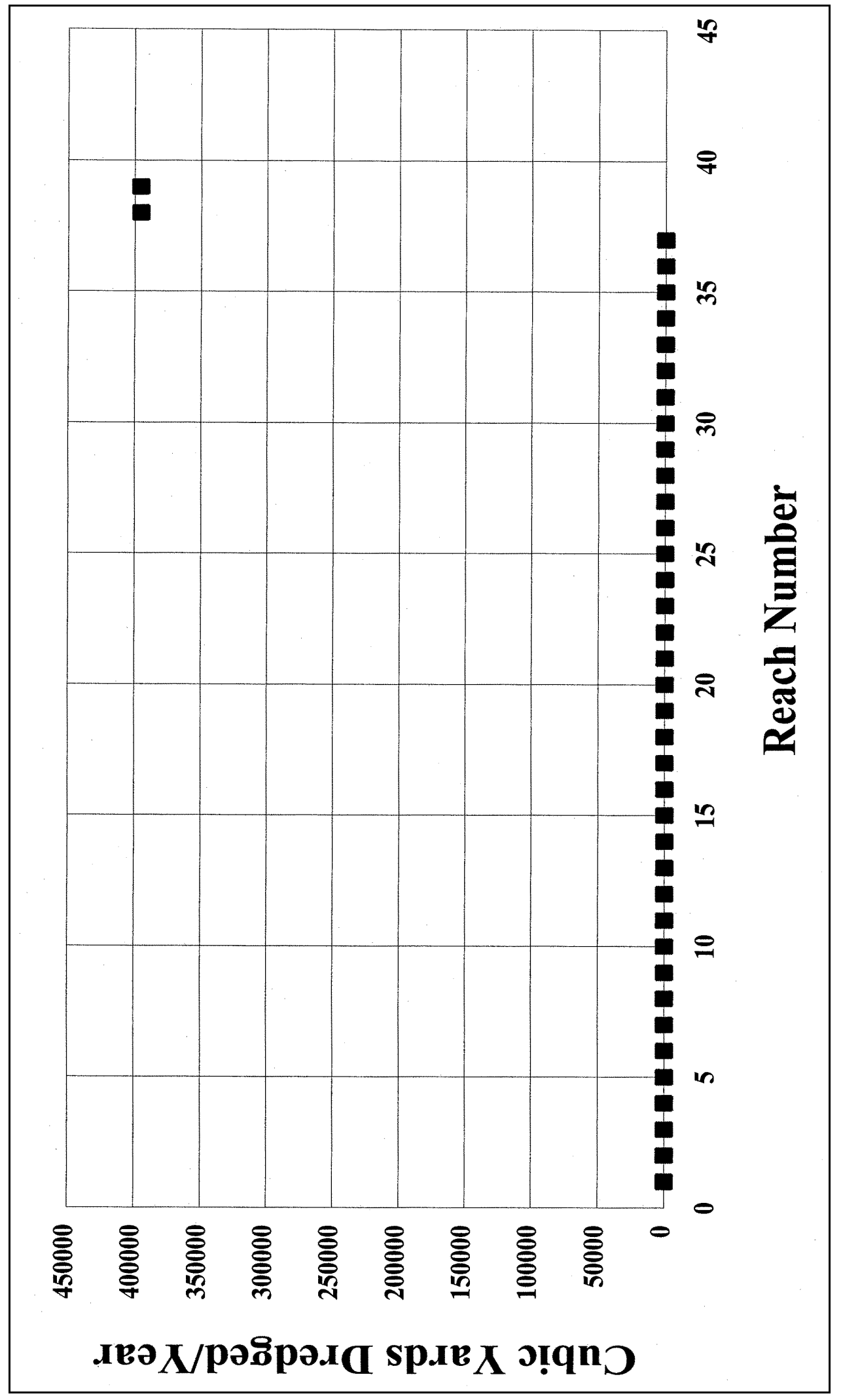

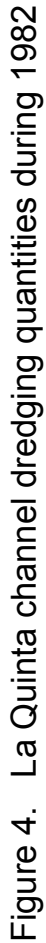




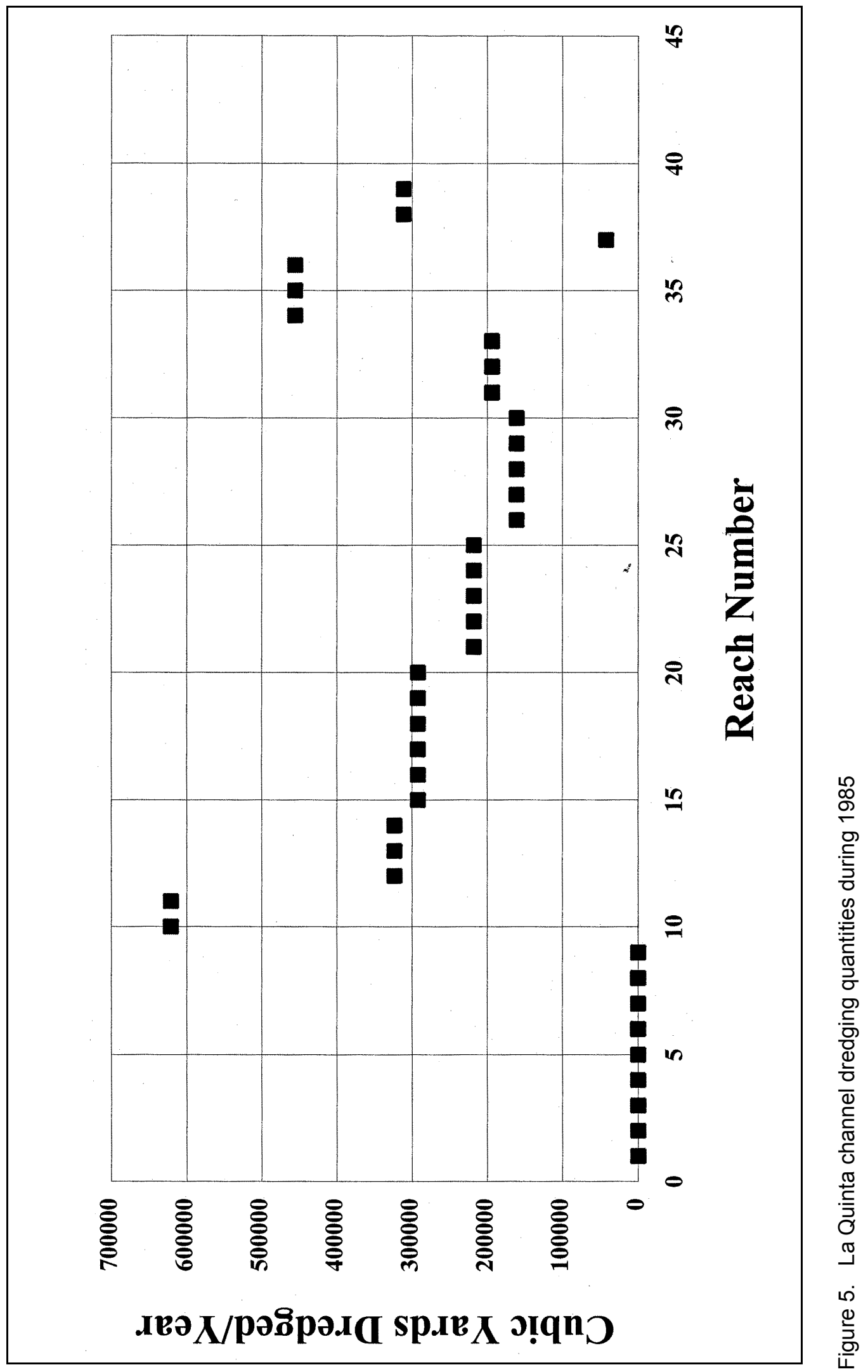




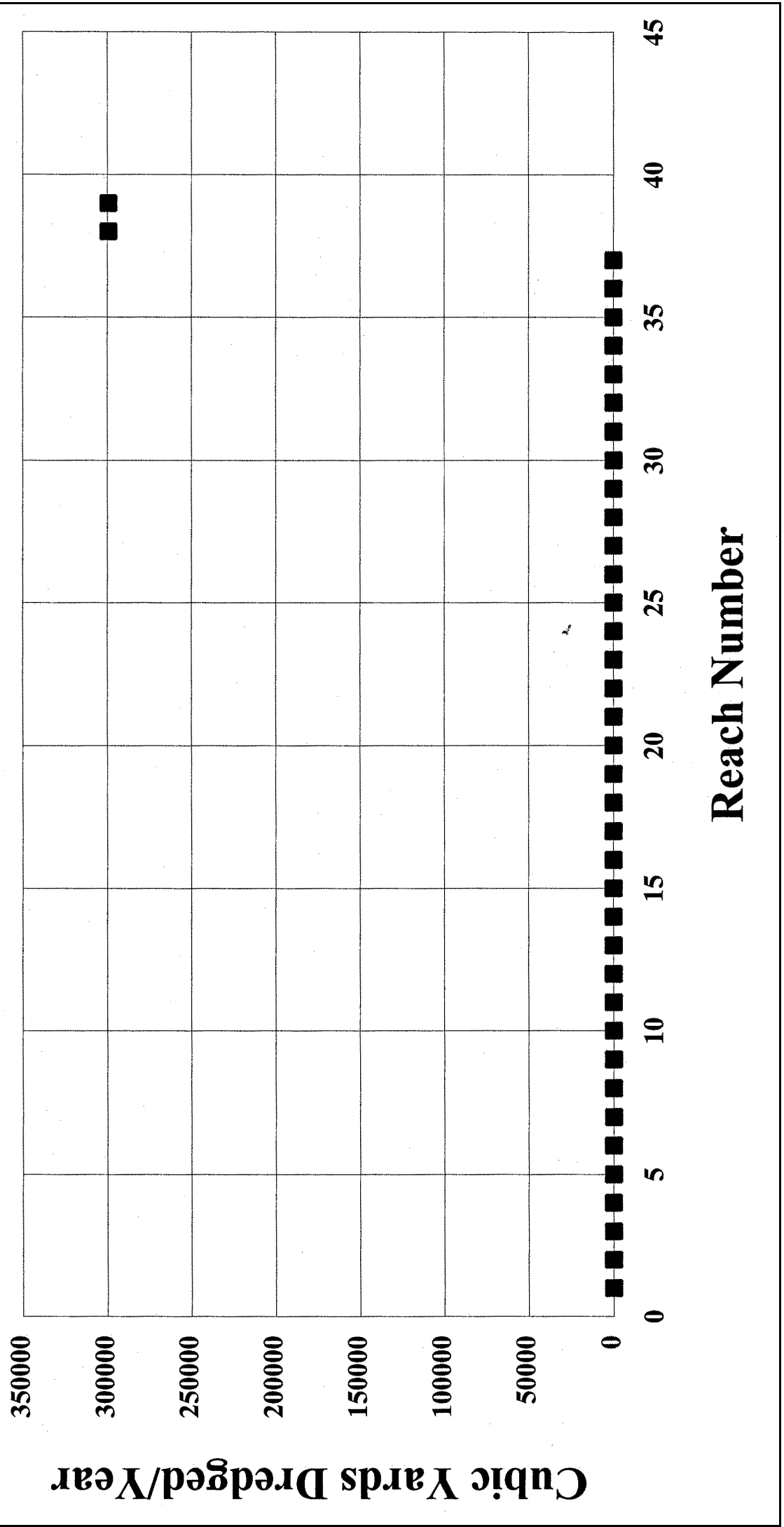

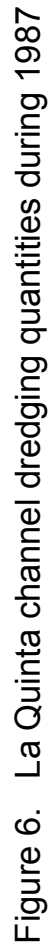




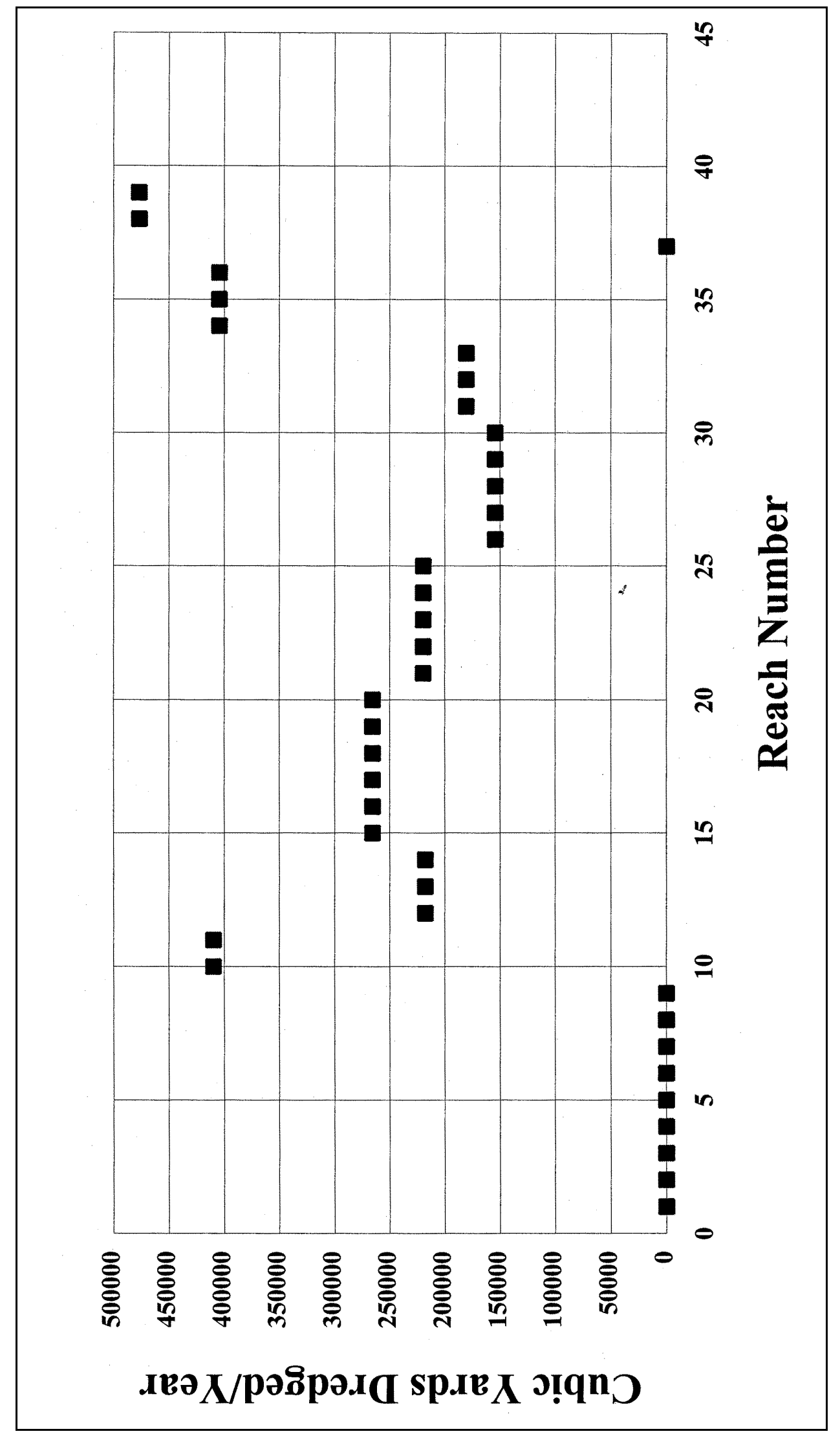

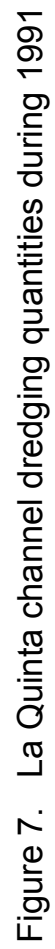




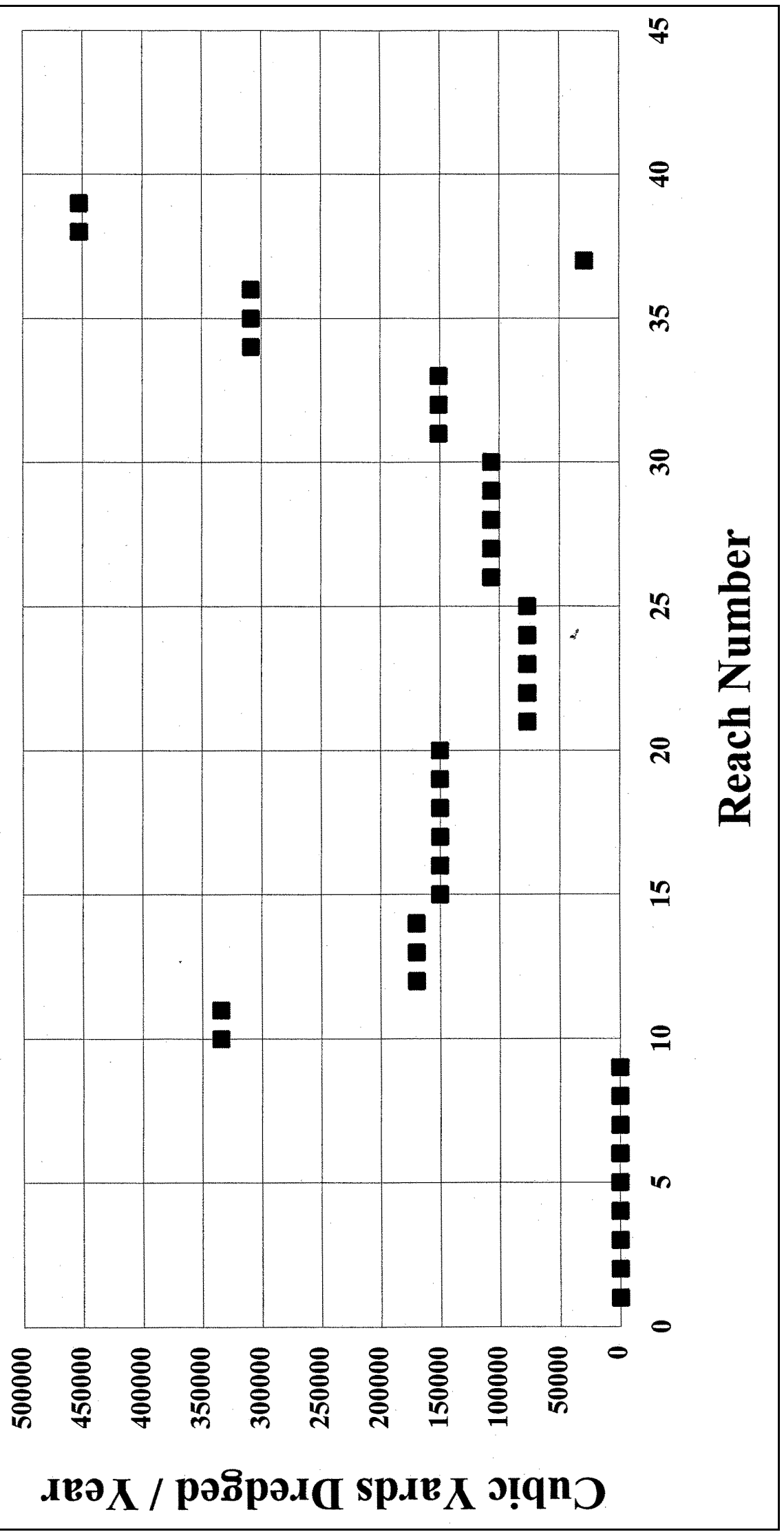

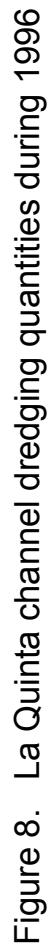




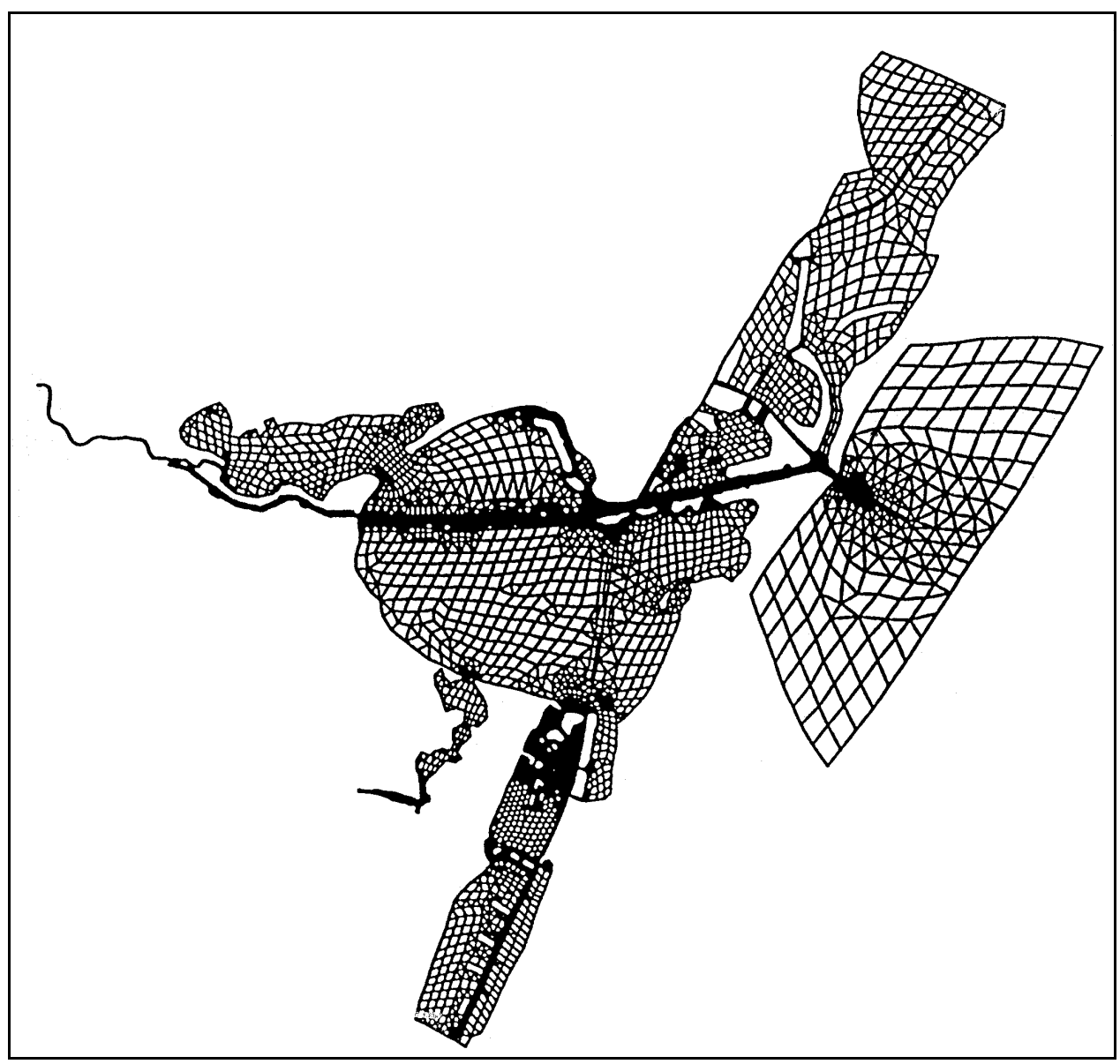

Figure 9. Grid used for numerical model 


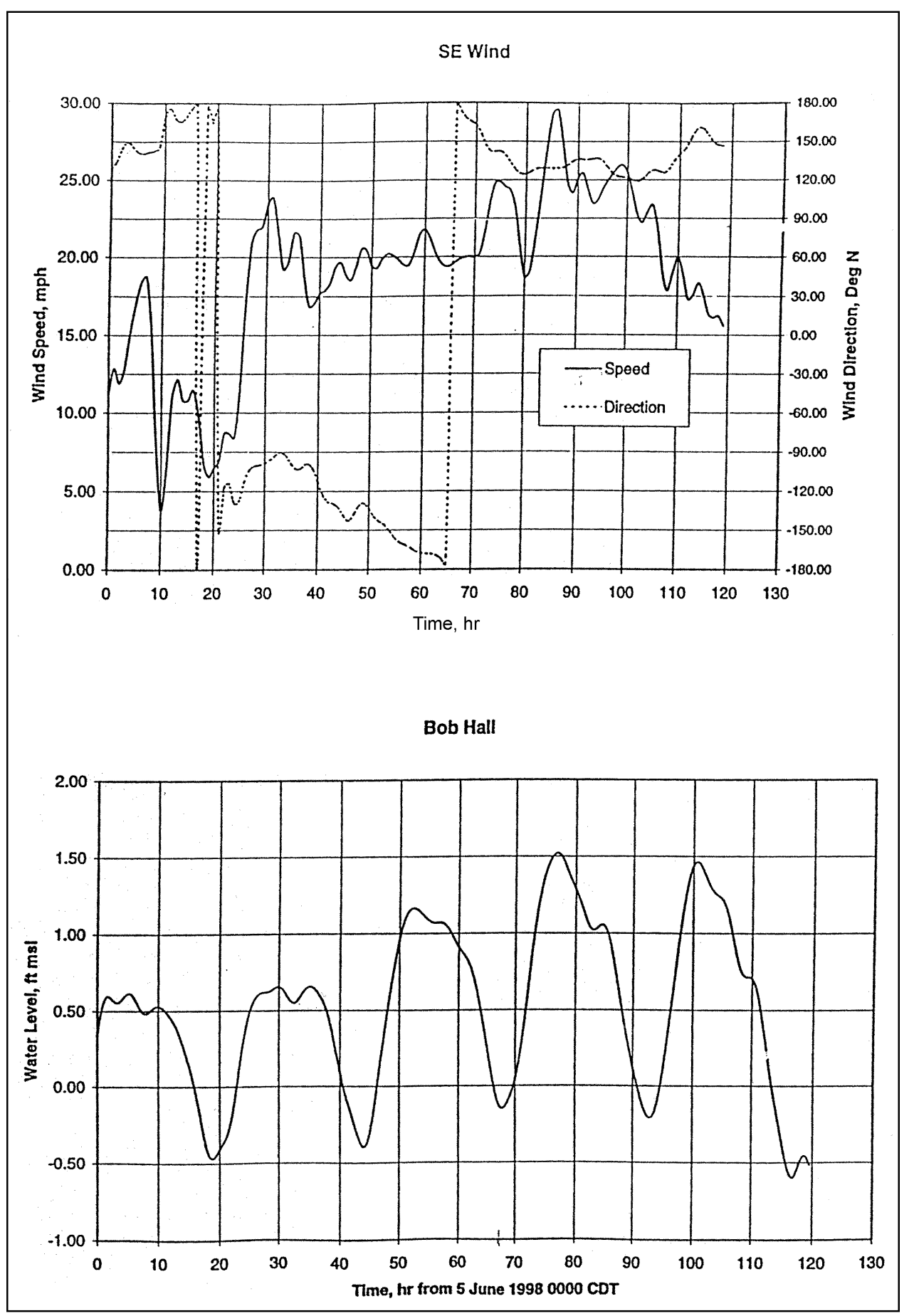

Figure 10. June tides and southeast wind selected for model run (measured at Bob Hall) (msl = mean sea level) 


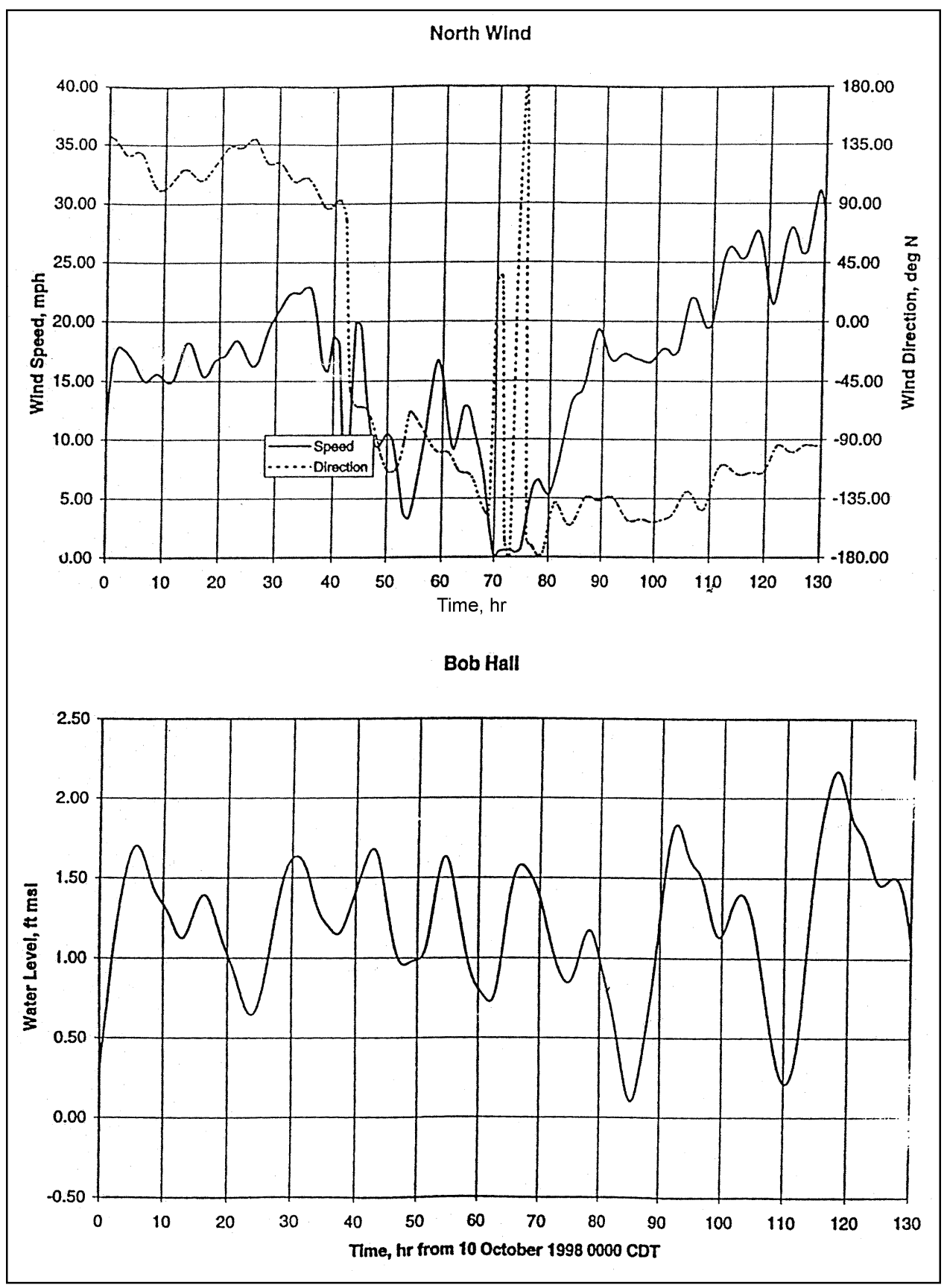

Figure 11. October tides and north wind selected for model run (measured at Bob Hall) 


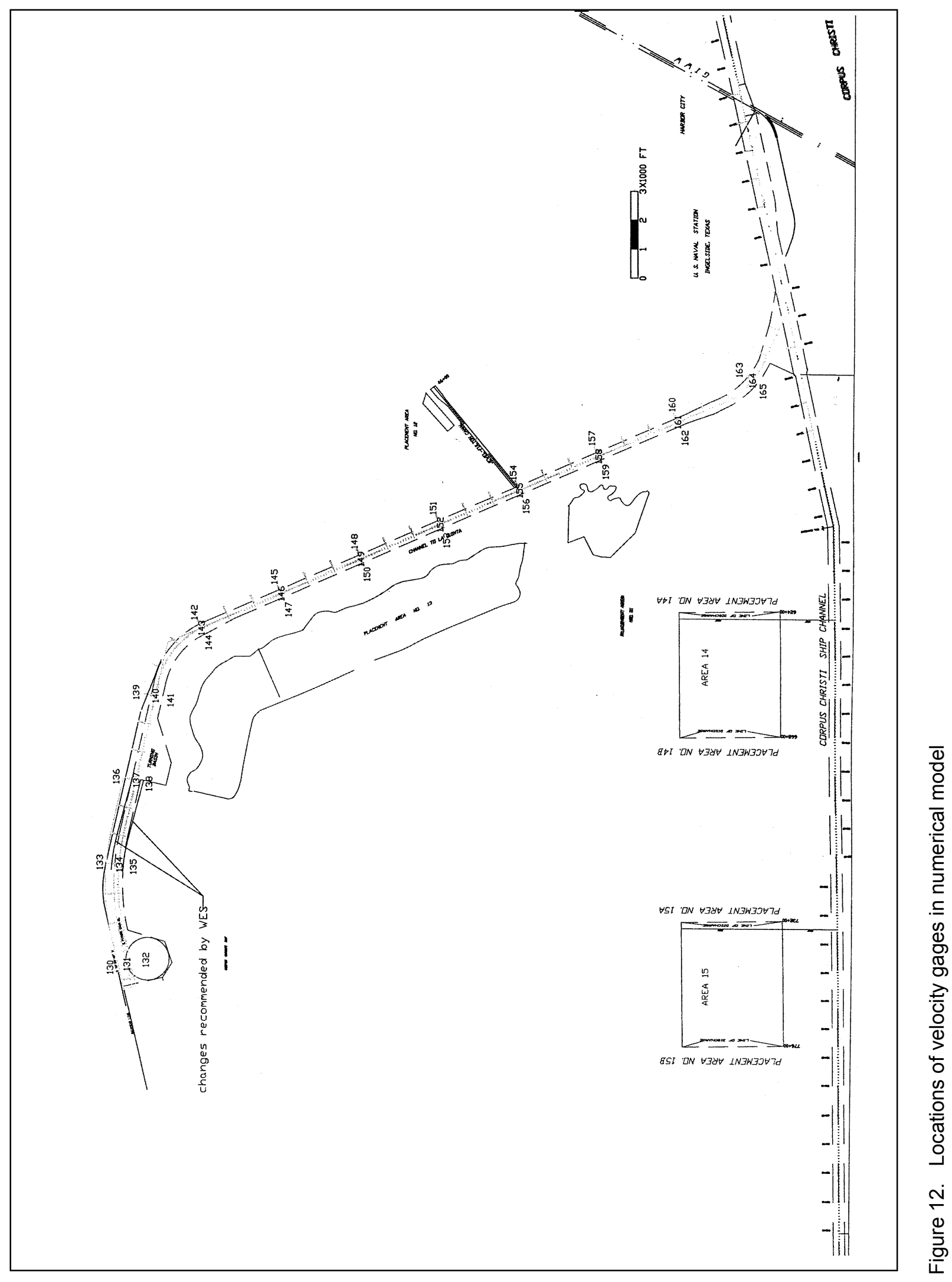




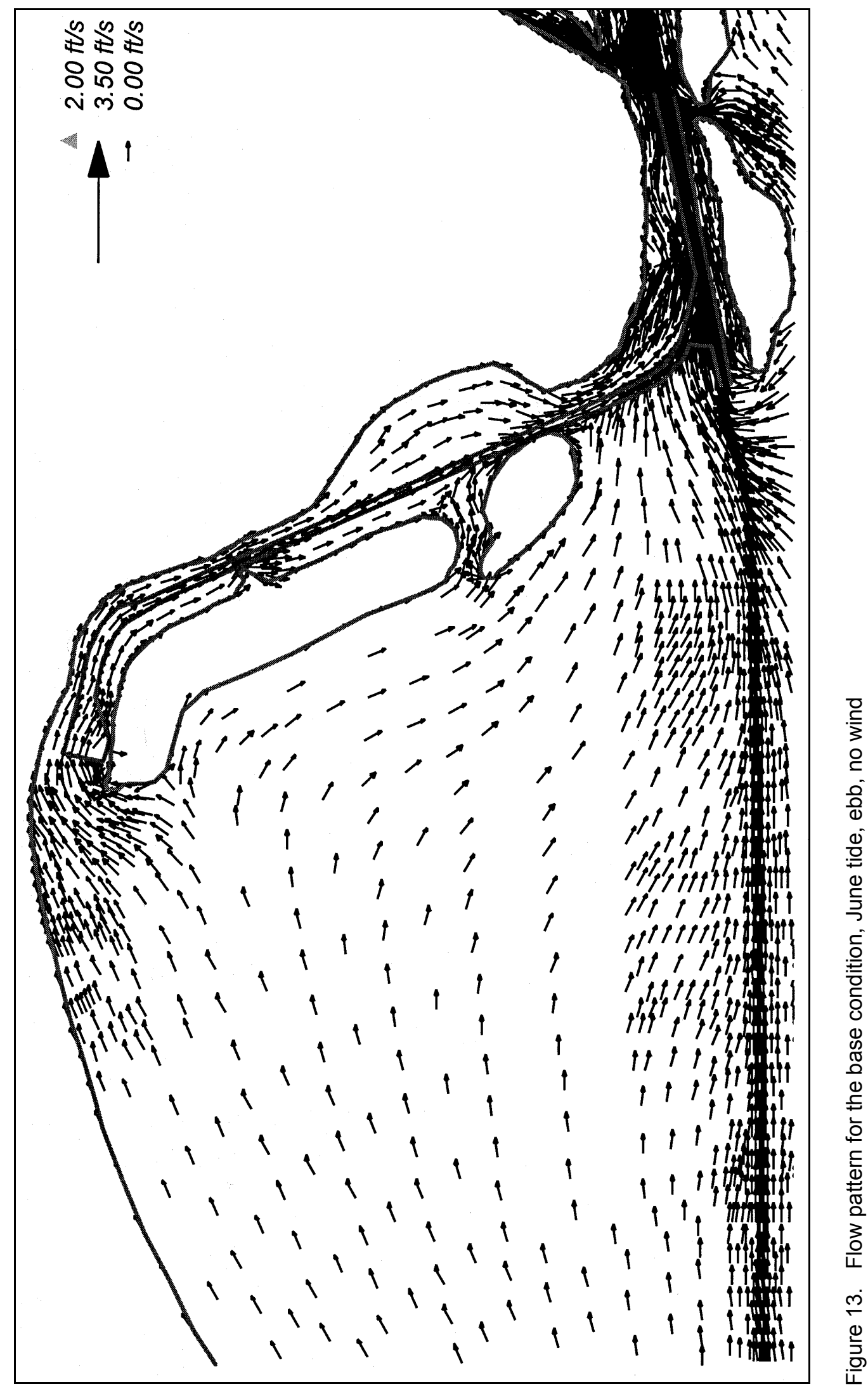




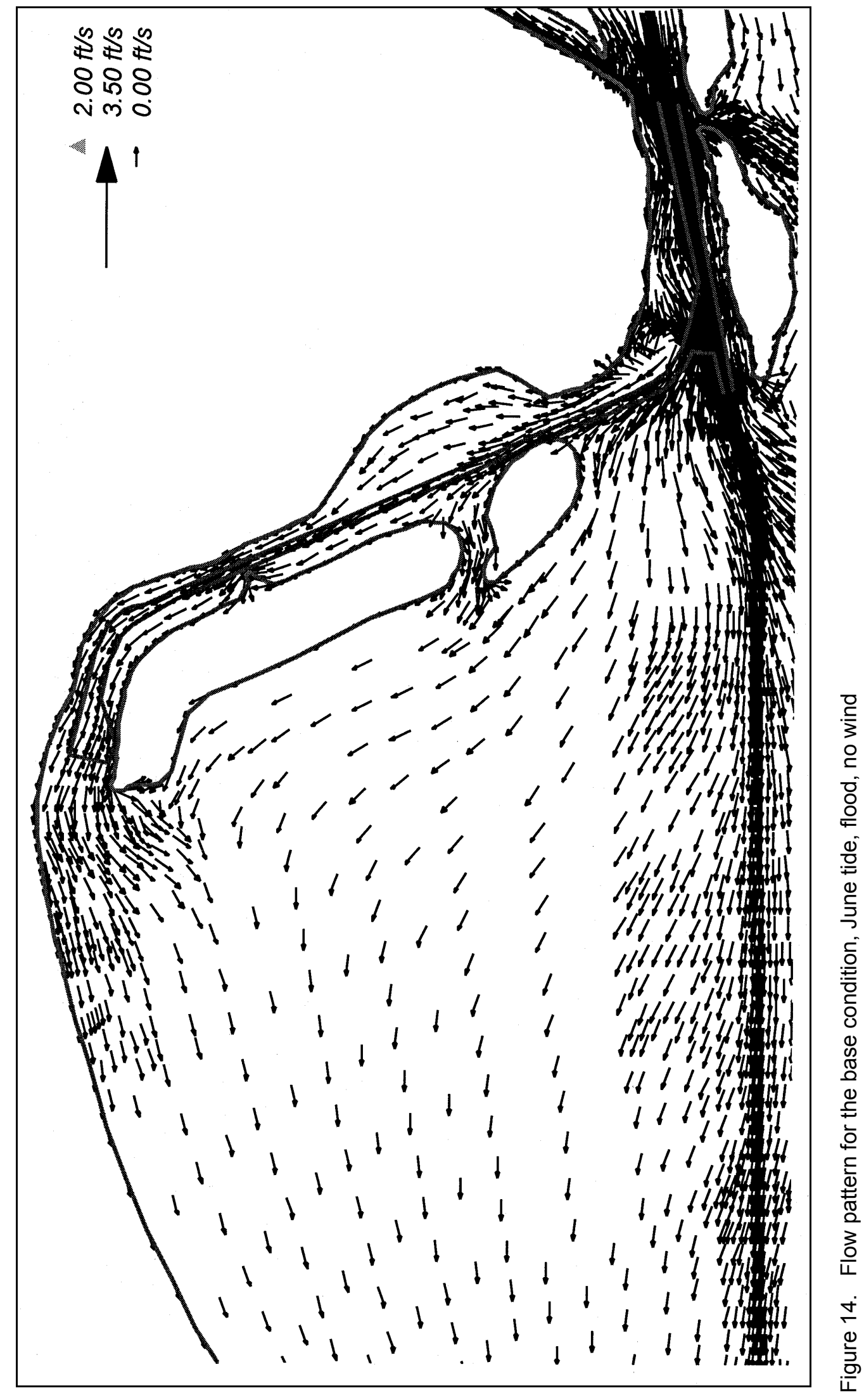




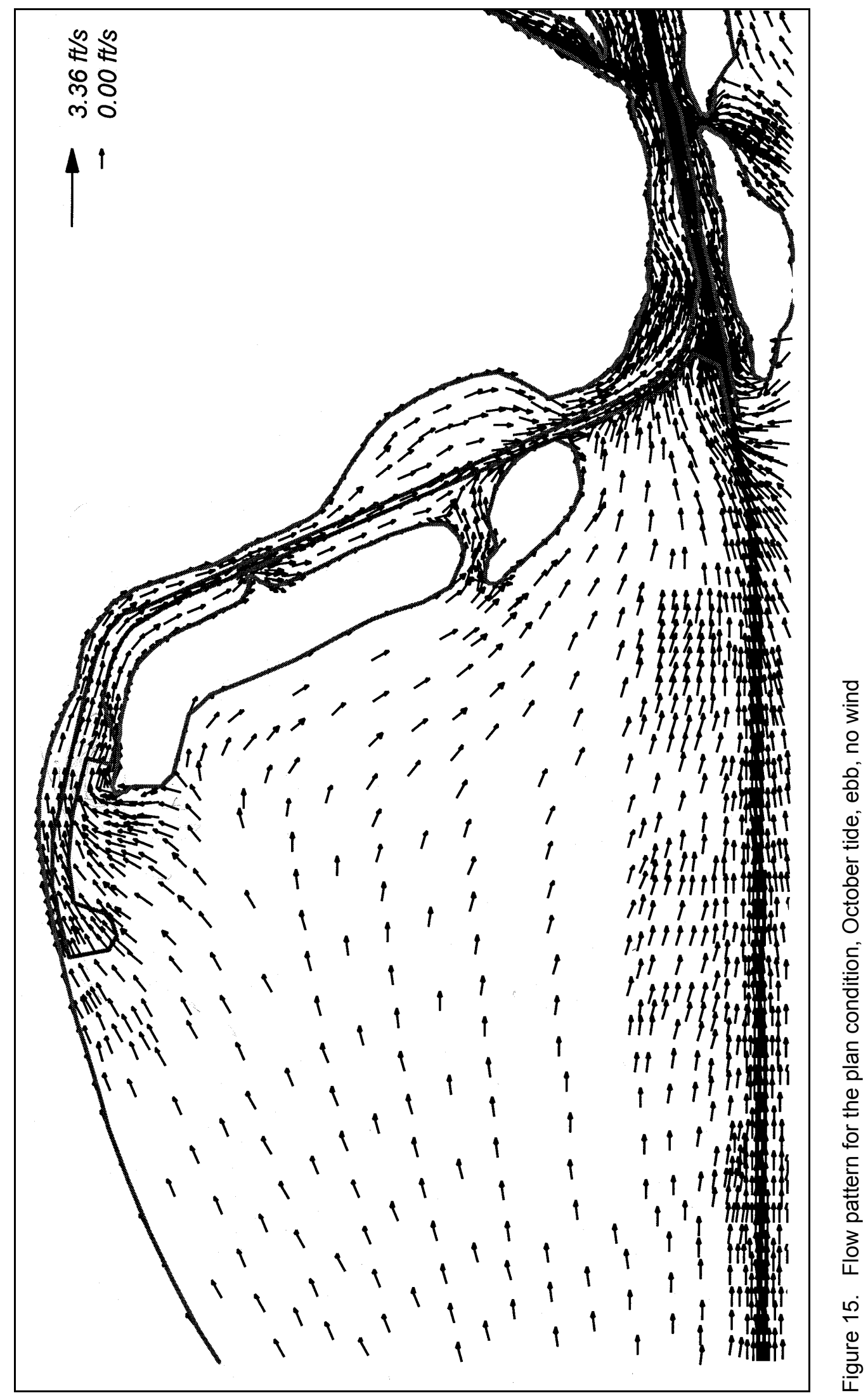




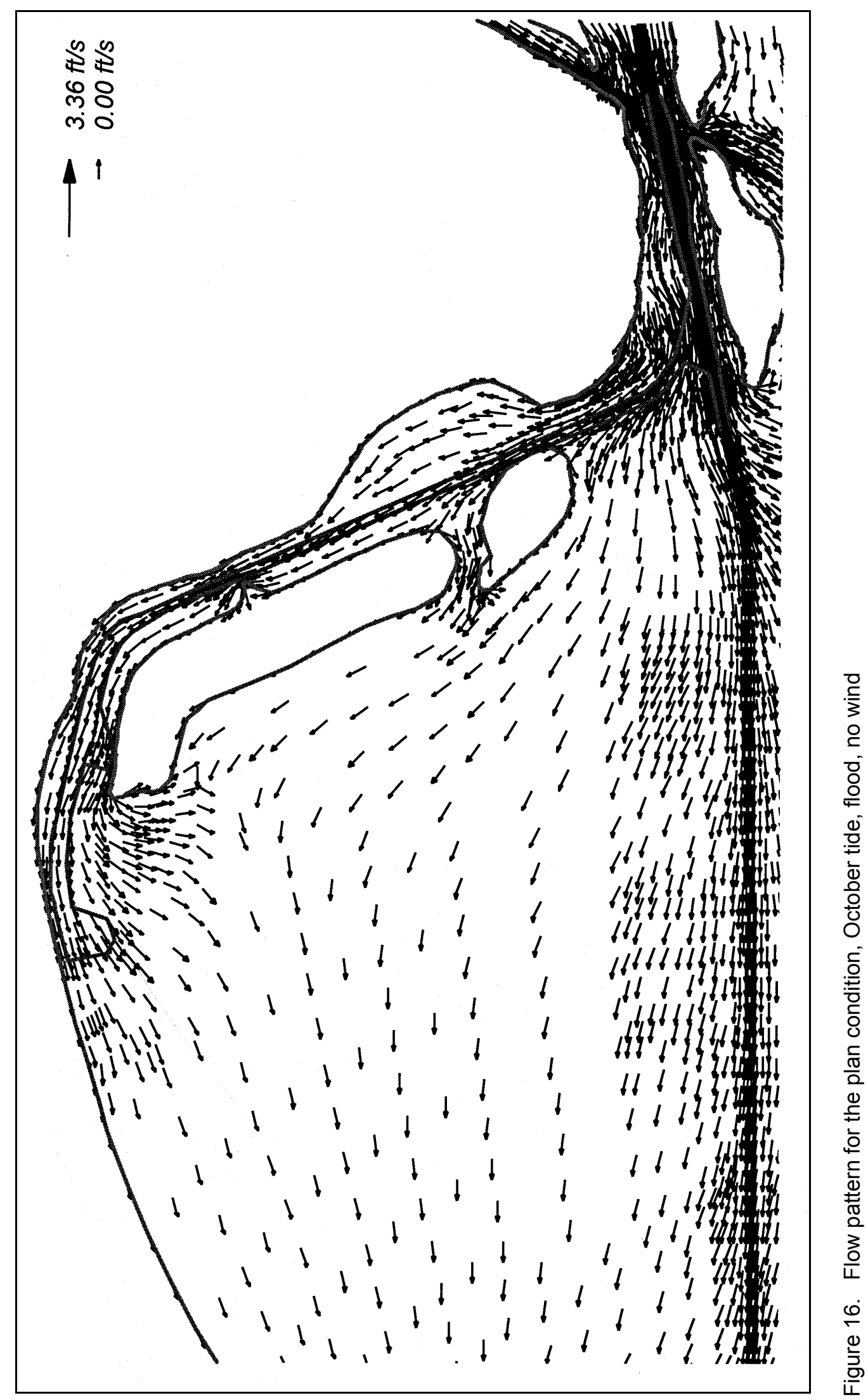




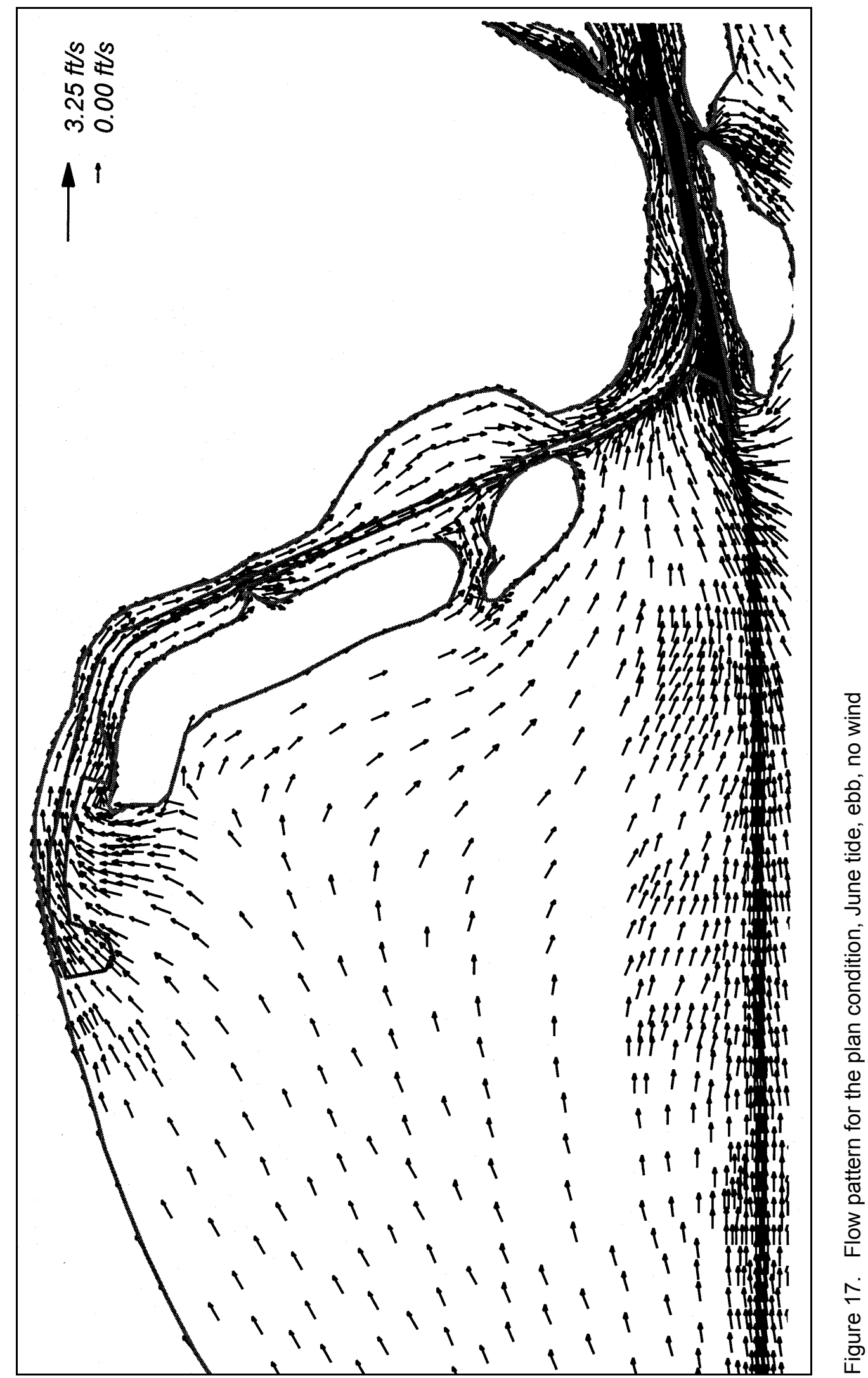




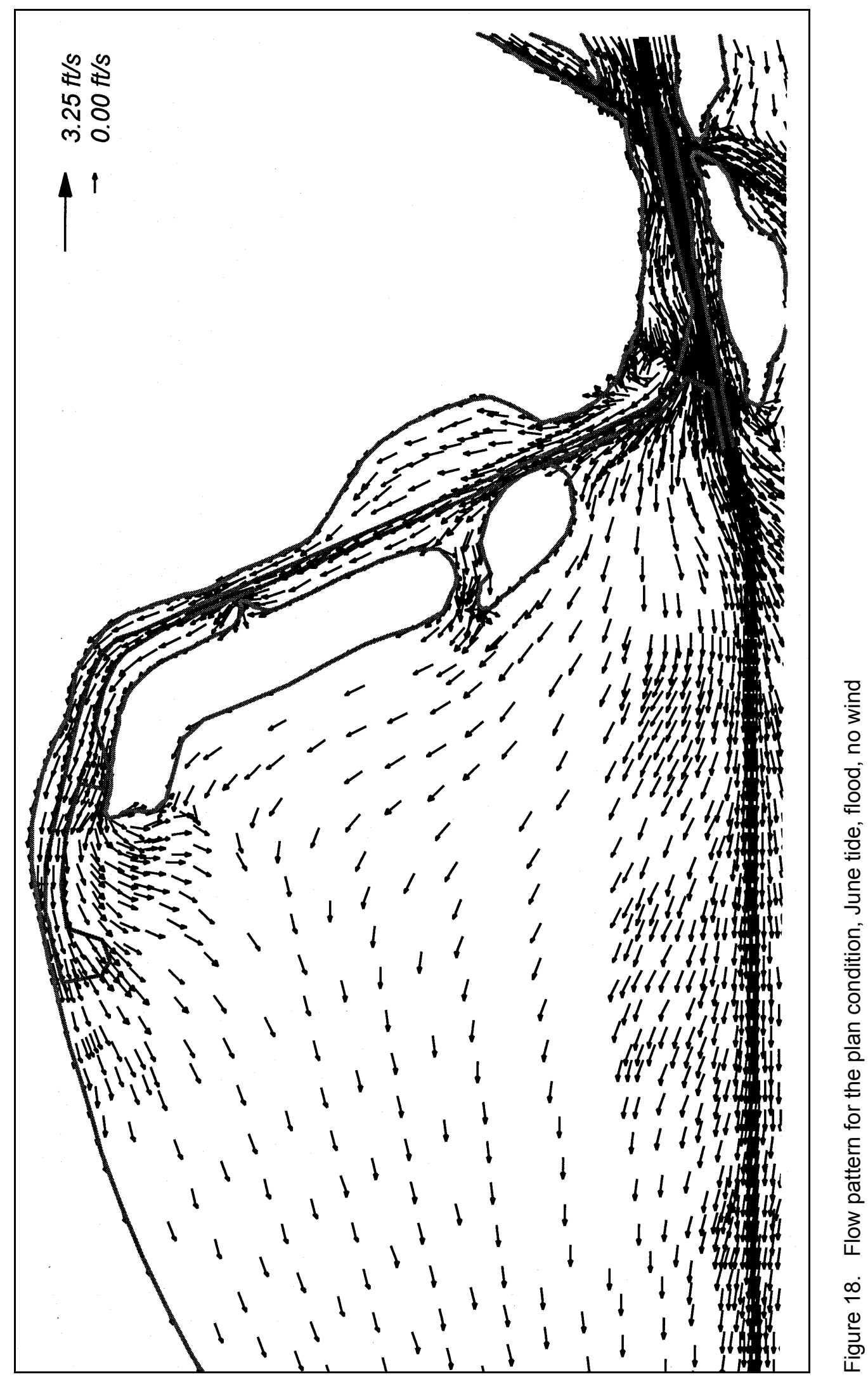




\section{Effect of a Barrier on Siltation in Extended La Quinta Channel}

\section{Introduction}

La Quinta navigation channel is located in the Corpus Christi Bay, Texas. It is connected to the Corpus Christi Ship Channel, which has a dead end on the west side where the Port of Corpus Christi is located. The Corpus Christi channel joins the Gulf of Mexico on the east side. The U.S. Army Engineer District, Galveston, is considering deepening and extension of the La Quinta navigation channel with the following options:

a. Extension of the existing channel with a new turning basin at the end of the extension, both at $45 \mathrm{ft}$ depth.

b. Deepening the existing channel to $50 \mathrm{ft}$ without extension.

c. Extension of the channel and deepening the entire channel to $50 \mathrm{ft}$.

The District requested the Coastal and Hydraulics Laboratory (CHL) of the U.S. Army Engineer Research and Development Center (ERDC), Vicksburg, MS, conduct a desktop study and provide an approximate estimation of future shoaling in the extended La Quinta ship channel for the first option given above.

A location map of the study area is shown in Figure 19. Detailed layout of the present La Quinta channel is shown in Figure 20. The proposed extension of the ship channel and a new turning basin are shown in Figure 21. It may be seen from Figure 20 that a substantial length of the existing channel is protected by a landmass on the Corpus Christi Bay side; however, the proposed extension does not have that advantage. Since the extended part of the channel is exposed to the action of waves and tidal currents, there is a concern for the safe navigation and berthing of vessels in the extended area. It was also feared that wind-induced waves might transport sediment in the northerly direction, resulting in channel siltation.

The Port of Corpus Christi Authority (PCCA) has proposed creation of a man-made barrier by placing dredged sediment as a part of the beneficial use of 
dredged material in creating a new habitat for birds and other aquatic life. Figure 22 shows a general layout, and Figure 23 shows a cross-sectional view of the proposed barrier. Both these figures were supplied by PCCA. PCCA has been negotiating with Pacific Engineering Inc. to design the cross section of the proposed island habitat to adequately protect the proposed container ship berth from waves and to keep sediment from transporting north into the ship channel and slip. The existing reach of shoreline in this location has been slightly accreting over time. Essentially, the proposed feature should be considered as an emergent barrier parallel to the northern shoreline of Corpus Christi Bay, which is exposed to waves. The barrier will be segmented with gaps between the islands. These openings would be shallow pockets of sand beach between hardened, protected islands. The gaps are not expected to function as channels that provide an effective connection between Corpus Christi Bay and the La Quinta channel extension.

This chapter describes a desktop study conducted to provide an approximate estimate of the effect of the proposed barrier on shoaling in the La Quinta channel extension.

\section{Barrier Details}

The physical details of the proposed barrier are given below:

Total length of barrier:

Width at top:

Crest elevation:

Number of islands and gaps:

Width of each gap:

Elevation of the crest of gap:

Width of submerged portion on the north side of barrier:

Crest elevation of submerged part on the north side of barrier
$7,800 \mathrm{ft}$

$500 \mathrm{ft}$

$+6 \mathrm{ft}$ mean low tide (MLT)

5

$150 \mathrm{ft}$

$-1 \mathrm{ft}$ MLT

$1,000 \mathrm{ft}$

$-1 \mathrm{ft}$ MLT

The crest elevation of $6 \mathrm{ft}$ is tentative at this stage. Actual elevation will be determined later in order to provide protection against waves generated in the bay. The crest elevation of the barrier does not affect the present study as long as it is above high water. 


\section{Numerical Model Results}

A vertically averaged, two-dimensional numerical model of the area was already available at CHL. The area included in the model as well as the model grids are shown in Figure 24. This model was previously used for the Texas Water Development Board for conducting a salinity study of the Corpus Christi Bay and surrounding area. Since the water depths in the study area were less than $100 \mathrm{ft}$, the negative values of water depths were added to an arbitrarily selected round number 100 so as to obtain all positive numbers in terms of elevations. Modifications were made to the model for increasing resolution within the navigation channel and other areas. The proposed extension of the channel and the new turning basin were incorporated. The model was validated earlier. ${ }^{1}$ Revalidation of the model specifically for the La Quinta area was not done because the work was not covered under the present scope of work. Hence, the model results are likely to be approximate.

One of the two main reasons for considering construction of a barrier has been the concern that wind-induced waves in Corpus Christi Bay may bring excessive sediment towards the newly extended navigation channel, resulting in deposition and higher maintenance dredging. Wind from the north is not a matter of concern as far as the sediment transport towards the extended channel is concerned. Data analysis indicated that the June tides are associated with southeast winds, whereas October tides are associated with the north wind.

The "base condition" in the model consisted of 1999 bathymetry with the present navigation channel at a 45-ft depth and the extended navigation channel as well as the new turning basin dredged to a 45-ft depth (Figure 25). The Plan 1 condition consisted of a 7,800-ft-long continuous barrier (Figure 26), and the Plan 2 condition consisted of a segmented barrier with the same total length (Figure 27). Although Port of Corpus Christi personnel wanted comments only on Plan 2, Plan 1 was also included in the study because of a possibility that the gaps provided initially may become completely ineffective in the future, thus making the barrier behave essentially as a continuous barrier. Figures 25-27 show water depths converted to elevation above a datum selected at $100 \mathrm{ft}$ as explained earlier. Conditions selected for running the numerical model were the same as those used in the previous study (Figure 28). Necessary correction was made for converting tidal elevations from mean sea level to mean low tide datum. The June tides were run without wind to examine the effect of tidal currents for a comparative evaluation of the extent of protection offered by the proposed barrier. The effect of wind is evaluated separately. Velocity data from the model were obtained for each of the three conditions at 22 locations in the vicinity of the barrier. Locations of these stations are shown in Figure 29. The model was run for an equivalent field duration of 5 days. Allowing time for initial spin-up and stabilization, model data from $70 \mathrm{hr}$ to $100 \mathrm{hr}$ were extracted for analysis.

\footnotetext{
${ }^{1}$ T. M. Smith, W. H. McAnally, and A. M. Teeter. (2000). "Validation of hydrodynamic model," Memorandum for Record, CEERD-HE-TE (1110-2-1403b), July 20, 2000.
} 


\section{Discussion of Flow Pattern}

Representative flow patterns obtained from the model for the base condition without a barrier for the flood and ebb stages of tide are shown in Figures 30 and 31, respectively. Figure 30 shows flow in the southwest direction during flood, and Figure 31 shows tidal flow in the north/northeast direction during ebb over the area where the new turning basin of the extended navigation channel would be located.

Figure 32 shows flood flow, and Figure 33 shows ebb flow with a continuous barrier in place on the south side. The flood flow shows an increase in strength within the gap between the barrier and the shoreline compared with the condition without the barrier. Figure 33 shows that the barrier arrests the northerly flow during ebb as would be expected. A large stagnant zone is created on the south side of barrier, and the currents are diverted towards the western end of the barrier. The diverted flow is roughly parallel to the local shoreline with the flow direction being predominantly eastward.

Figure 34 shows flood flow, and Figure 35 shows ebb flow with a segmented barrier in place on the south side. Again, the flood flow shows an increase in strength within the gap between the barrier and the shoreline, compared with the condition without the barrier. There is no significant difference between either in the flow pattern or in the velocity magnitudes obtained with a continuous and a segmented barrier.

\section{Discussion of Flow Velocity}

Velocity data from the numerical model were obtained at 22 locations in the vicinity of the barrier, for the base, continuous barrier and segmented barrier conditions. Superposed velocity plots for the three conditions are presented in Figures 36-57 for stations 1 through 22, respectively. No significant difference is noticed between the results of continuous and segmented barrier conditions. Since the gaps between adjacent islands are small in width $(150 \mathrm{ft})$ and shallow in depth (-1 MLT), they do not allow any significant flow through them and hence do not have any measurable impact on the flow pattern or velocity magnitudes in the region.

Table 9 gives a comparison of maximum velocities observed on numerical models at 22 stations for the conditions without and with a segmented barrier. At the outset, it may be noticed that the velocity within the gap between the shoreline and the barrier (stations 12 and 13) almost doubles with the barrier in place. This is because of a restricted cross section after the barrier is placed. At stations located within the present turning basin (stations 1 and 2), extended channel (stations 3 -9), and new turning basin (stations 10 and 11), a decrease in velocity magnitudes is noticed. In the area between the barrier and channel extension, a decrease in velocity is noticed. At the gaps between the islands (stations 15, 16, and 17), a decrease in velocity is noticed; however, in the first gap between the shoreline and the barrier, a sharp increase is observed. This is because the ebb 


\begin{tabular}{|c|c|c|c|c|}
\hline \multicolumn{5}{|c|}{$\begin{array}{l}\text { Table } 9 \\
\text { Comparison of Maximum Velocities Observed on the Numerical Model }\end{array}$} \\
\hline \multirow[b]{2}{*}{ Station } & \multicolumn{2}{|c|}{ Maximum Velocity, ft/s } & \multirow[b]{2}{*}{$\begin{array}{l}\text { Percent } \\
\text { Change }\end{array}$} & \multirow[b]{2}{*}{ Location } \\
\hline & \begin{tabular}{|l|} 
Base, Without \\
Barrier
\end{tabular} & \begin{tabular}{|l|} 
Segmented \\
Barrier
\end{tabular} & & \\
\hline 1 & 0.140 & 0.120 & 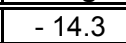 & Present turning basin \\
\hline 2 & 0.085 & 0.072 & -15.3 & \\
\hline 3 & 0.097 & 0.082 & -15.5 & Extended ship channel \\
\hline 4 & 0.118 & 0.098 & -16.9 & \\
\hline 5 & 0.127 & 0.103 & -18.9 & \\
\hline 6 & 0.120 & 0.100 & -16.7 & \\
\hline 7 & 0.102 & 0.090 & -11.8 & \\
\hline 8 & 0.092 & 0.085 & -07.6 & \\
\hline 9 & 0.082 & 0.082 & 00.0 & \\
\hline 10 & 0.061 & 0.072 & +18.0 & New turning basin \\
\hline 11 & 0.048 & 0.060 & +25.0 & \\
\hline 12 & 0.085 & 0.185 & +117.6 & Gap between shoreline and barrier \\
\hline 13 & 0.085 & 0.165 & +94.1 & \\
\hline 14 & 0.072 & 0.069 & -04.2 & \\
\hline 15 & 0.080 & 0.050 & -42.2 & Island gaps, north of barrier \\
\hline 16 & 0.070 & 0.040 & -42.8 & \\
\hline 17 & 0.070 & 0.045 & -50.0 & \\
\hline 18 & 0.042 & 0.043 & +02.4 & \\
\hline 19 & 0.025 & 0.065 & +116.0 & \\
\hline 20 & 0.072 & 0.065 & -09.7 & North of barrier, south of channel extension \\
\hline 21 & 0.101 & 0.075 & -25.7 & \\
\hline 22 & 0.110 & 0.100 & -09.1 & \\
\hline
\end{tabular}

flow guided by the present shoreline tries to follow the established route to the north but is arrested except for a small gap.

Velocities at stations 15 - 19 represent local conditions very close to the barrier and hence any change in velocity is only of local significance. Velocities at the new turning basin and the gap between the shoreline and barrier increase, whereas, in general, a decrease in velocities on the order of 15 to 18 percent is noticed along the present and extended channels. Velocities in the area between the extension and the barrier also decrease. It may be concluded that almost the entire area of channel extension experiences a decrease in velocity on the order of 15 percent. This is expected to increase deposition of suspended sediment in the area. At the same time the bed load will be predominantly arrested except for some sediment moving around the western tip of the barrier.

\section{Wave Impact Evaluation}

Wind is known to be an important parameter at Corpus Christi Bay, influencing currents and sediment transport. The previous desktop study of La Quinta channel (Chapter 1) indicated that the north wind caused about a 50-percent increase in channel current velocity for October tide, whereas the southeast wind nearly doubled the June tidal current velocity in the channel. This is because the southeast wind generally has a higher magnitude over longer duration than the north wind. A wind rose diagram for the Corpus Christi area (Figure 58) shows the following predominant pattern: 
a. Wind is from north-northeast and north directions during the 5 months from October through February.

$b$. During the remaining 7 months, the wind is predominantly from southsoutheast and southeast directions.

c. Wind from the southerly directions has higher wind speeds than the wind from northerly directions.

A look at the barrier layout shown in Figure 22 will indicate that the barrier will protect the turning basin quite well against waves from southeast and southsoutheast directions. Waves generated by wind from south and southwest would have been more critical; however, these wind directions do not seem to prevail at the site. Waves generated in the bay from any southerly direction will refract around the western tip of the barrier and will propagate in the area of the new turning basin. The magnitude of refracted waves in this area can be determined from refraction diagrams for various incident wave heights and directions.

Incident wave heights and wave periods have been estimated (Table 10) for the following parameters using a procedure given in the Shore Protection Manual (1984) of the U.S. Army Corps of Engineers:

a. Maximum fetch: $60,000 \mathrm{ft}$

b. Sustained wind speeds: $10,20,25$, and $30 \mathrm{mph}$

c. Water depth: $15 \mathrm{ft}$

\section{Table 10 \\ Estimated Wave Heights for Given Wind Conditions}

\begin{tabular}{||l|l|l|l|l||}
\hline \hline Fetch, $\mathrm{ft}$ & $\begin{array}{l}\text { Wind speed } \\
\mathrm{mph}\end{array}$ & $\begin{array}{l}\text { Wind stress } \\
\text { Factor, mph }\end{array}$ & $\begin{array}{l}\text { Estimated Wave } \\
\text { Height, } \mathrm{ft}\end{array}$ & $\begin{array}{l}\text { Estimated Wave } \\
\text { Period, sec }\end{array}$ \\
\hline \hline 60,000 & 10 & 12 & 1.0 & 2.2 \\
\hline 60,000 & 20 & 28 & 2.4 & 3.3 \\
\hline 60,000 & 25 & 37 & 2.8 & 3.5 \\
\hline 60,000 & 30 & 47 & 3.3 & 3.7 \\
\hline \hline
\end{tabular}

Maximum wave-induced velocity of water particles near bed and the resulting maximum bed shear stress were calculated for four selected wave conditions (Table 11).

\begin{tabular}{|c|c|c|c|}
\hline \multicolumn{4}{|c|}{$\begin{array}{l}\text { Table } 11 \\
\text { Estimated Bed Velocity and Bed Shear Stress for Given Wave } \\
\text { Conditions }\end{array}$} \\
\hline Wave Height, $\mathrm{ft}$ & Wave Period, sec & Max. Bed Velocity, ft/s & Max. Bed Shear Stress, Pa \\
\hline 1.0 & 2.2 & 0.067 & 0.002 \\
\hline 2.2 & 2.4 & 0.780 & 0.30 \\
\hline 3.5 & 2.0 & 1.032 & \begin{tabular}{|l|}
0.53 \\
\end{tabular} \\
\hline 3.7 & 3.5 & 1.330 & \begin{tabular}{|l|}
0.88 \\
\end{tabular} \\
\hline
\end{tabular}


It is estimated that wind speed higher than $25 \mathrm{mph}$ will generate waves with sufficient energy to transport bed sediment at the site.

\section{Siltation Predictions}

Siltation in the turning basin and ship channel will take place due to bed load transport and suspended load transport. Bed load transport requires a higher shear stress. Preliminary computations show that wave action will generate adequate shear stress that can result in bed load transport. Waves also often bring a substantial amount of sediment from the bed into suspension. Since tidal currents are weak, they may not be able to carry bed load; however, they will be able to carry suspended material, which may later deposit in areas of low turbulence and shear. While the barrier will be effective in arresting a substantial amount of sediment being transported as bed load, the same barrier will create a sheltered area of lower turbulence on the north side, which will result in an increased rate of suspended sediment deposition. Ideally, it would greatly help if it were possible to estimate the total quantity of bed load and suspended load separately for a given site. Although equations and methods to do that are available in the literature, their application requires extensive field data on parameters such as currents, waves, and wind and also extensive sediment data for verification. A real-life application is more complicated due to spatial and temporal variations in these parameters. In the absence of such data, sediment deposition estimates need to be made based on limited computations, field data, and judgment based on site conditions.

For purposes of shoaling estimates, the La Quinta channel was divided into 11 zones in the previous desktop study (Chapter 1). These are shown in Figure 59. The estimated dredging quantities in zone $\mathrm{J}$, which is the extension of the ship channel, was 95,000 cu yd/year and for zone $\mathrm{K}$, which is the new turning basin, 127,000 cu yd/year.

Limited field data on sediment show that the material depositing in the present La Quinta channel consists of predominantly silt and clay. It is therefore reasonable to assume that the source of sediment is suspended material entering and moving along the channel. While providing estimates of shoaling in the extended channel and turning basin, an additional source, namely bed sediment transport resulting from wave action, had to be included.

In the earlier desktop study, 20 percent of total estimated deposition in the new turning basin and extended channel was attributed to wave-induced sedimentation. This amounted to $25,000 \mathrm{cu}$ yd in the turning basin and $19,000 \mathrm{cu}$ yd in the extended channel. Some sediment will bypass around the western tip of the barrier and some will enter directly through the gap, which will reach the basin. It is therefore assumed that the barrier would arrest 60 percent of the wave-induced sediment going towards the new turning basin and 100 percent of the sediment going to the extended channel. Hence, the arrested sediment will be $15,000 \mathrm{cu}$ yd from the basin and $19,000 \mathrm{cu}$ yd from the channel. The total reduction in siltation would thus be $34,000 \mathrm{cu} y d / y e a r$. 


\section{Conclusions}

The following conclusions may be drawn:

a. The proposed 7,800-ft-long barrier will provide shelter to the new turning basin area from southeasterly waves, which have a predominant occurrence during the year. The extent of protection will depend mainly on the incident wave direction.

b. The proposed barrier will partly arrest wave-induced northerly bed load transport. It will also create stagnant zones on both the north and south sides of the barrier. Over a matter of a few years, the sediment accumulated on the south side of the barrier will be expected to move westward under wave-induced current along the direction of the barrier. This sediment will travel around the western tip of the barrier, enter on the lee side, and start depositing because that area lacks adequate energy to move it further on. While some of the bed load may enter the western portion of the new turning basin, the eastern half of the basin and the extended ship channel is not expected to be affected for the reason that this area is energy-deficient for bed load transport.

c. The local velocity in the gap between the shoreline and the barrier nearly doubles with the barrier in place. Hence, the amount of wave-induced suspended sediment brought in through the gap is expected to increase compared to the conditions without the barrier.

d. The combined effect is a substantial decrease in bed load sediment and a marginal increase in suspended sediment. The net effect is estimated to result in the following annual dredging quantities in the new turning basin and the extended channel in comparison with the quantities without a barrier.

\begin{tabular}{||l|r|l||}
\hline Zone & Without Barrier & With Barrier \\
\hline \hline New turning basin & $127,000 \mathrm{cu}$ yd/year & $112,000 \mathrm{cu}$ yd/year \\
\hline Extended channel & $95,000 \mathrm{cu}$ yd/year & $76,000 \mathrm{cu}$ yd/year \\
\hline Total & $222,000 \mathrm{cu}$ yd/year & $188,000 \mathrm{cu}$ yd/year \\
\hline
\end{tabular}

e. It may be noted that the above quantities are only approximate estimates based on limited data and limited study. These estimates should meet the requirements of a feasibility type study and planning.

f. Since channel extension and provision of a new turning basin are entirely new construction, they will result in a substantial change in local water depths. This is expected to have a severe impact on submerged bottom slopes. Local sloughing and slope adjustment to a regime may take a few years, during which the sedimentation in the new construction could be due to reasons other than those taken into consideration for the present study.

g. Travel of locally accumulated sediment on the south side of the barrier will also change the sediment regime of the area in future years. 


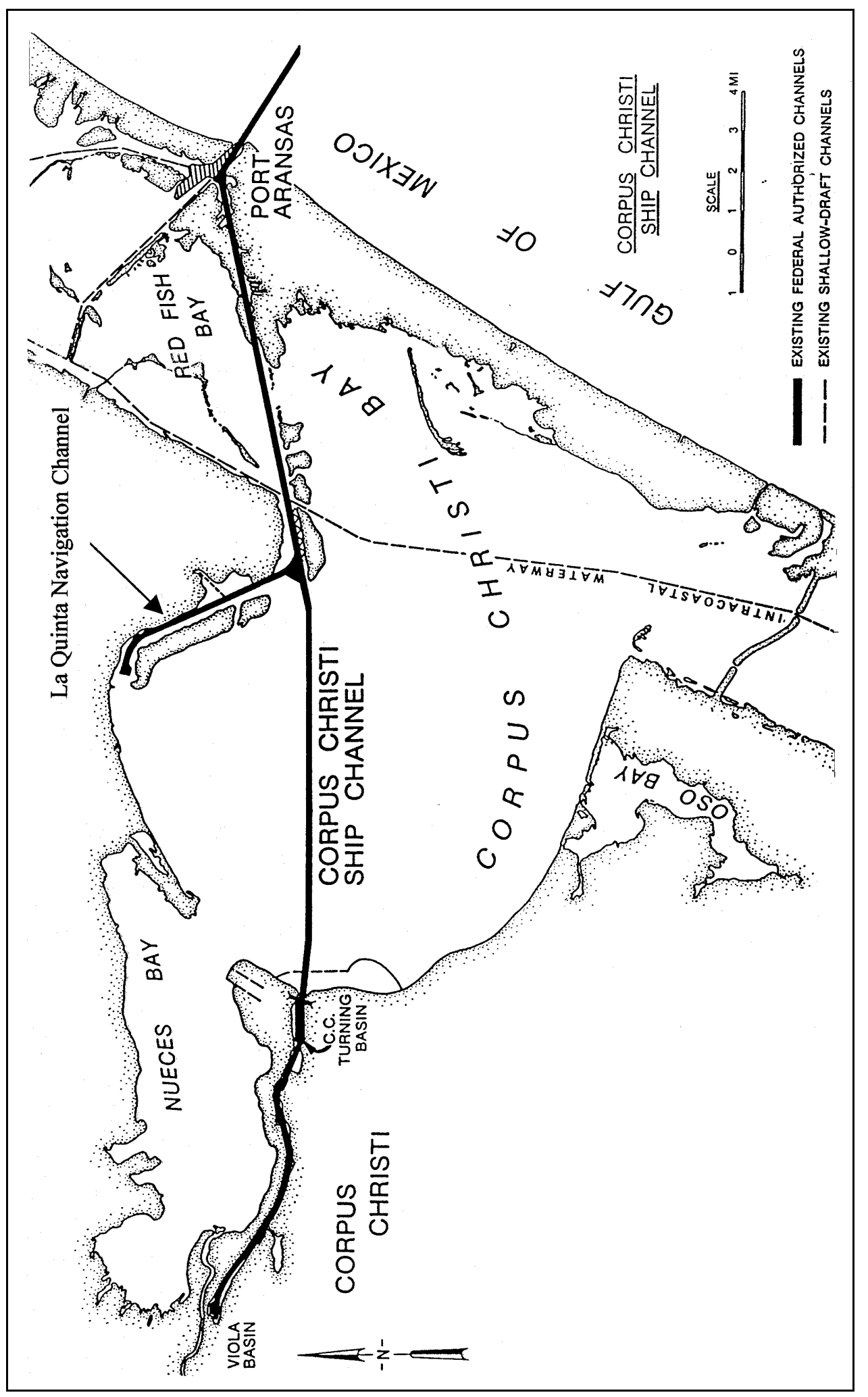

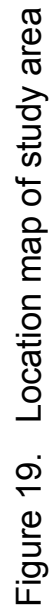




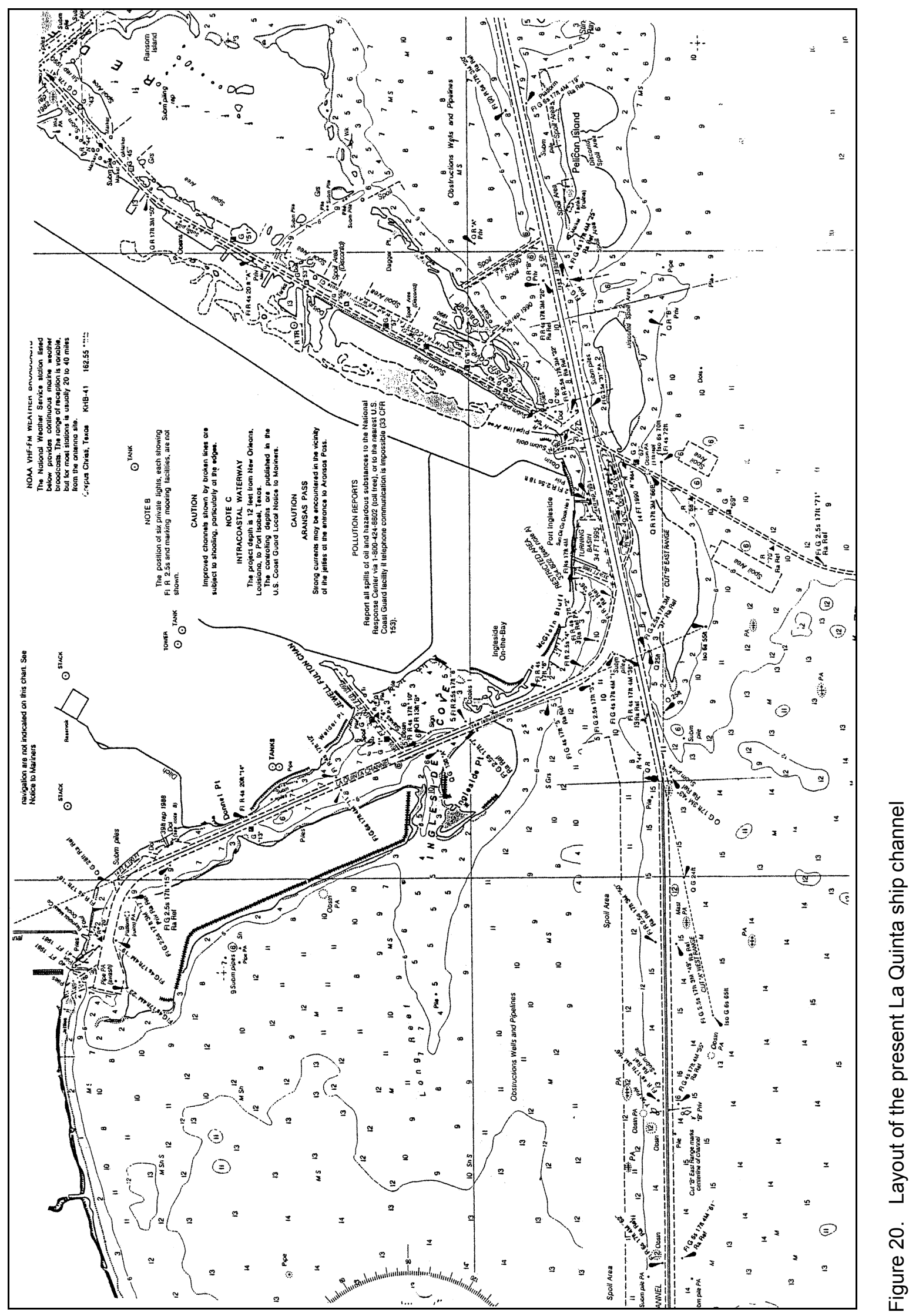




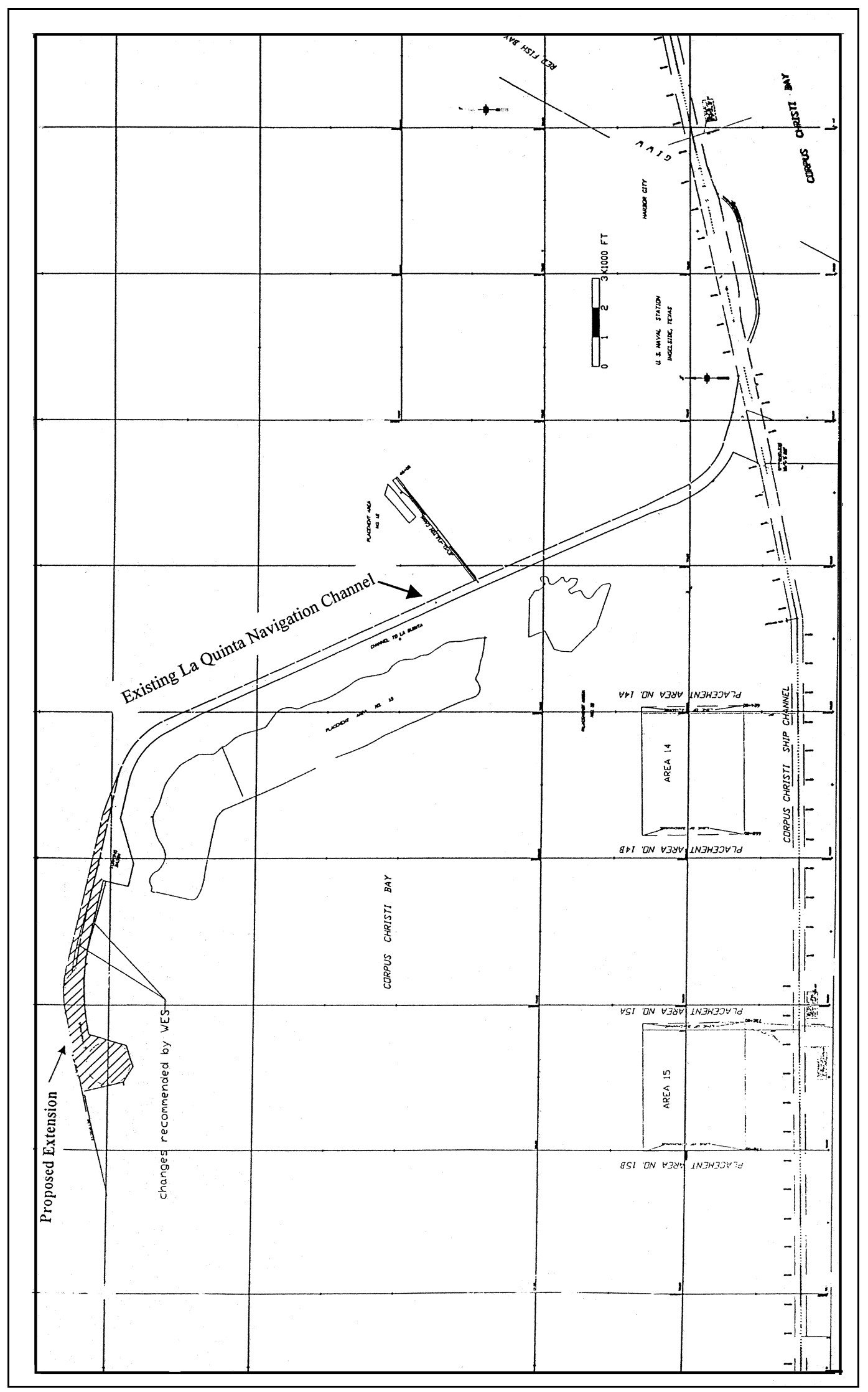

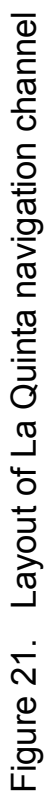




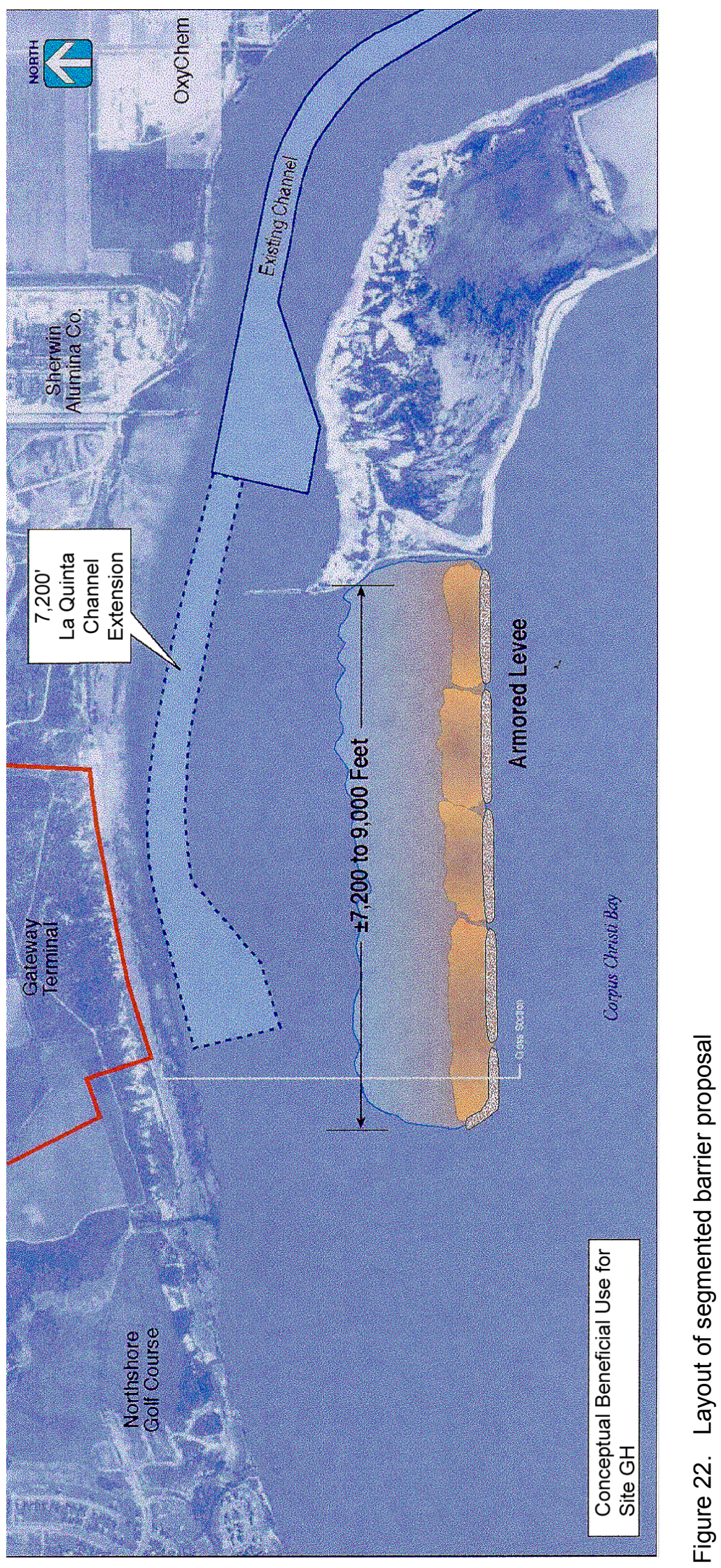




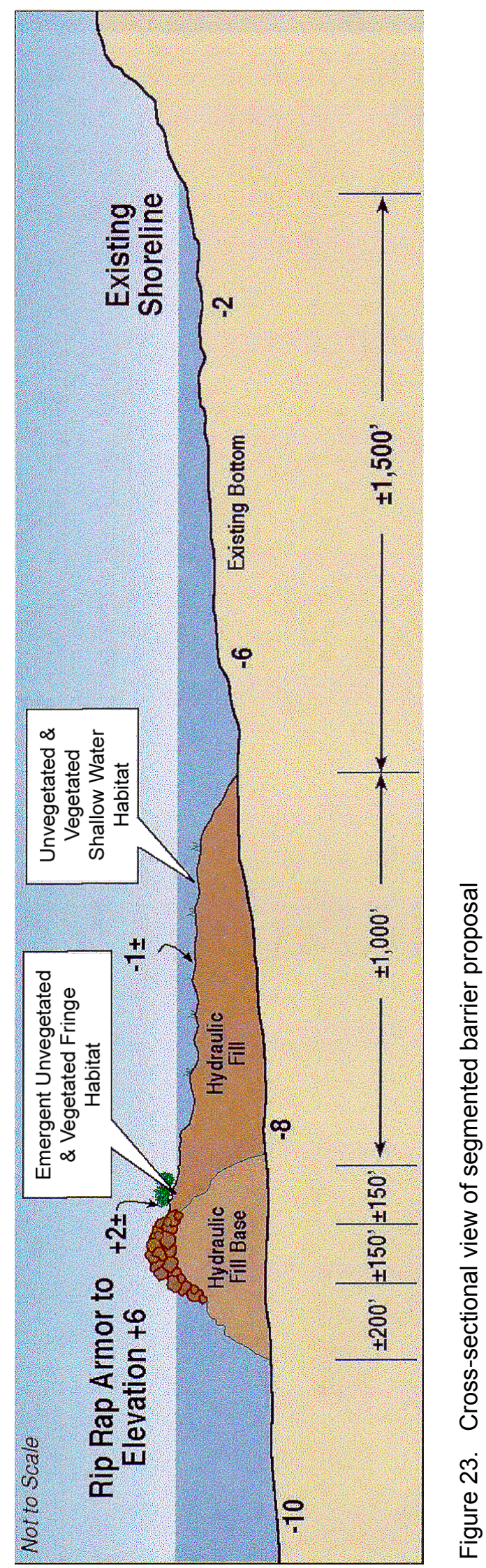




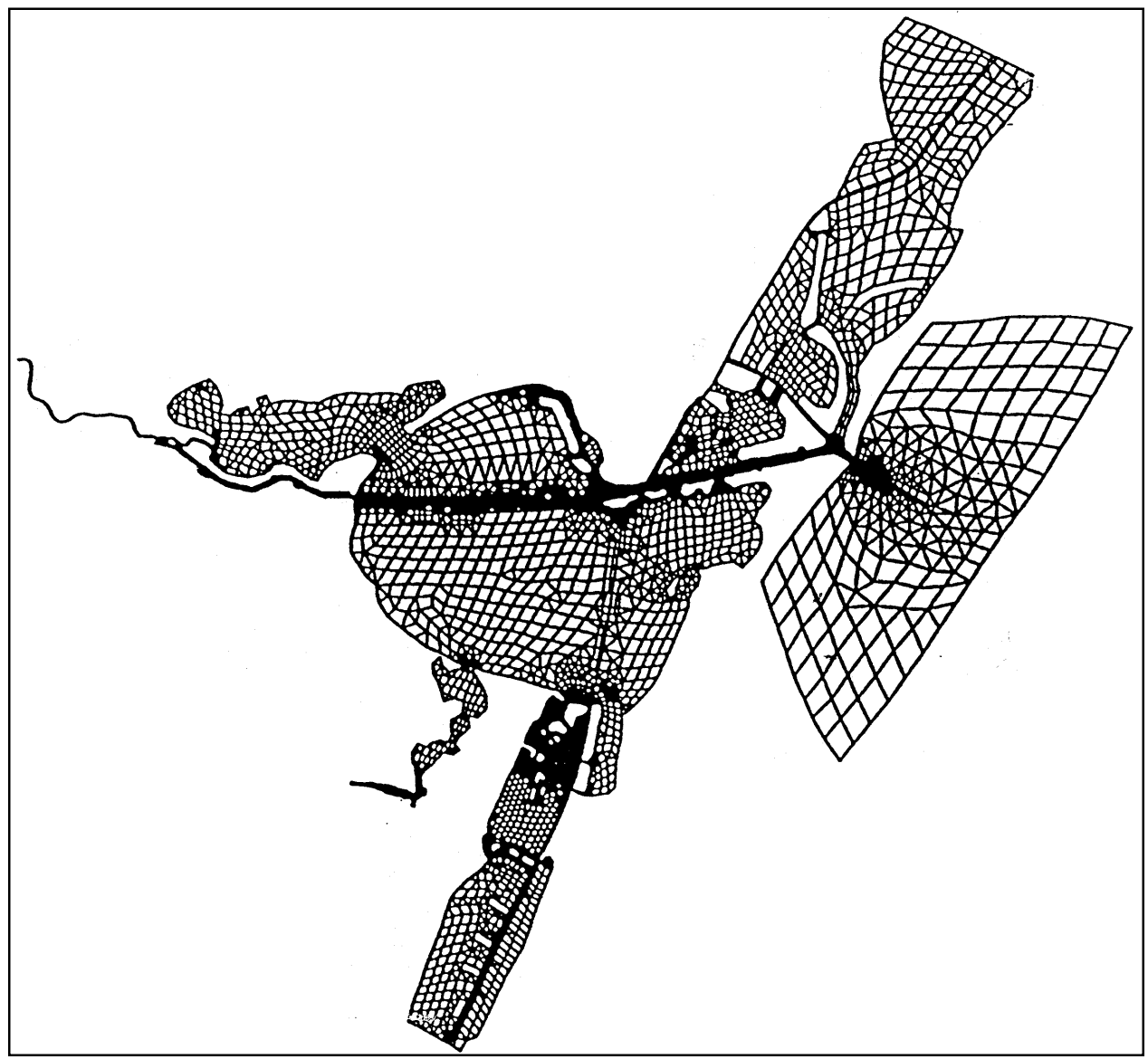

Figure 24. Grid used for numerical model 


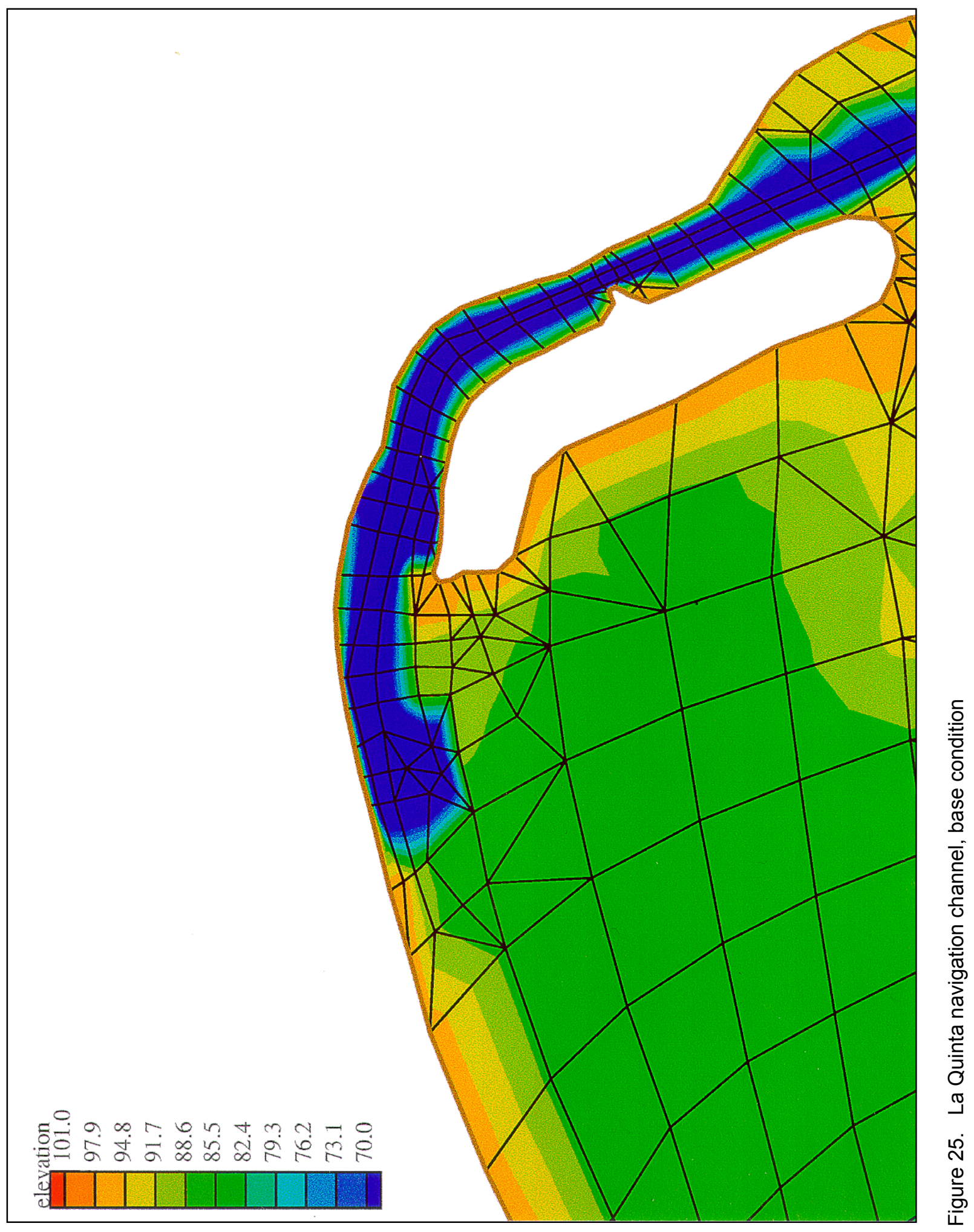




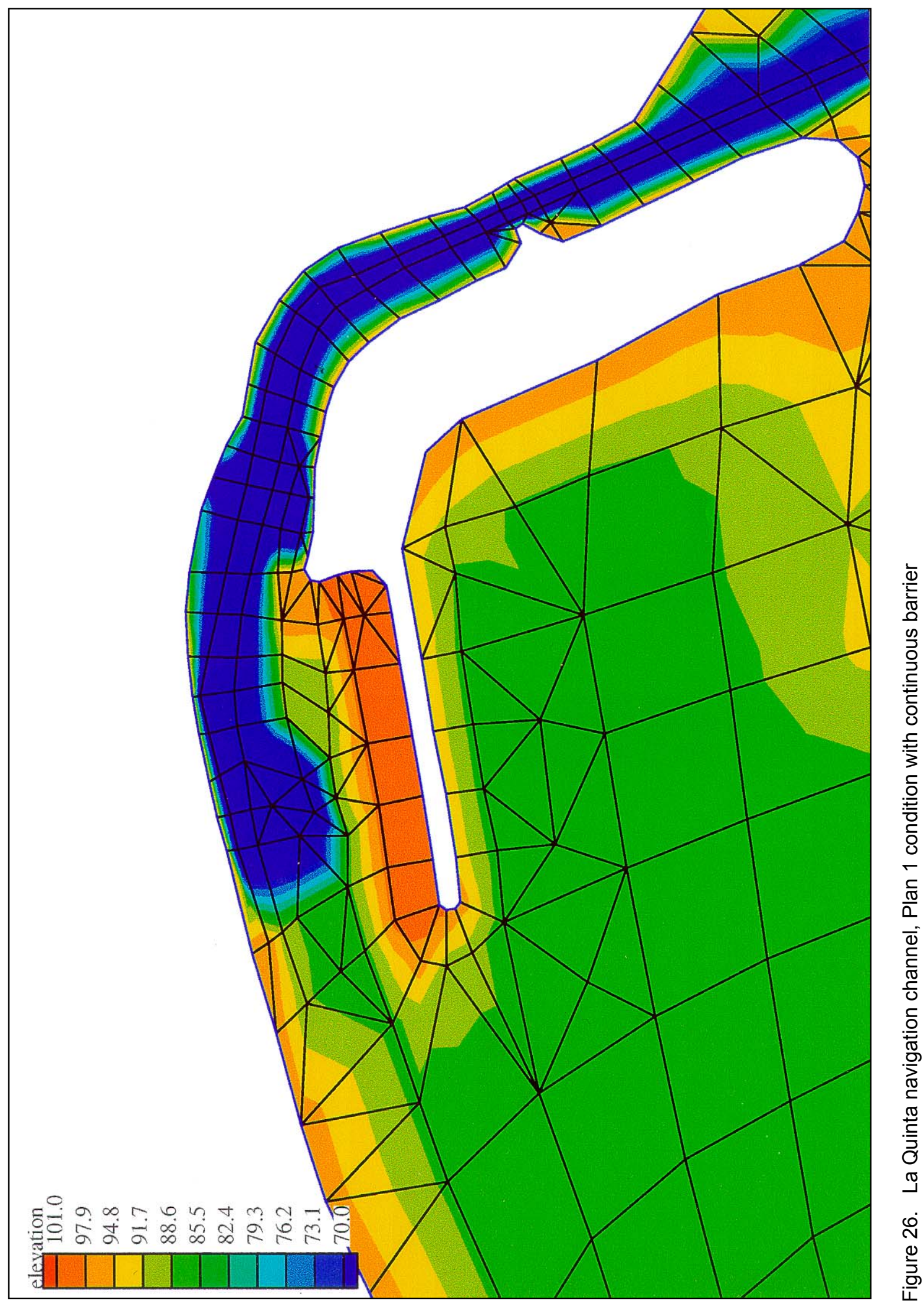




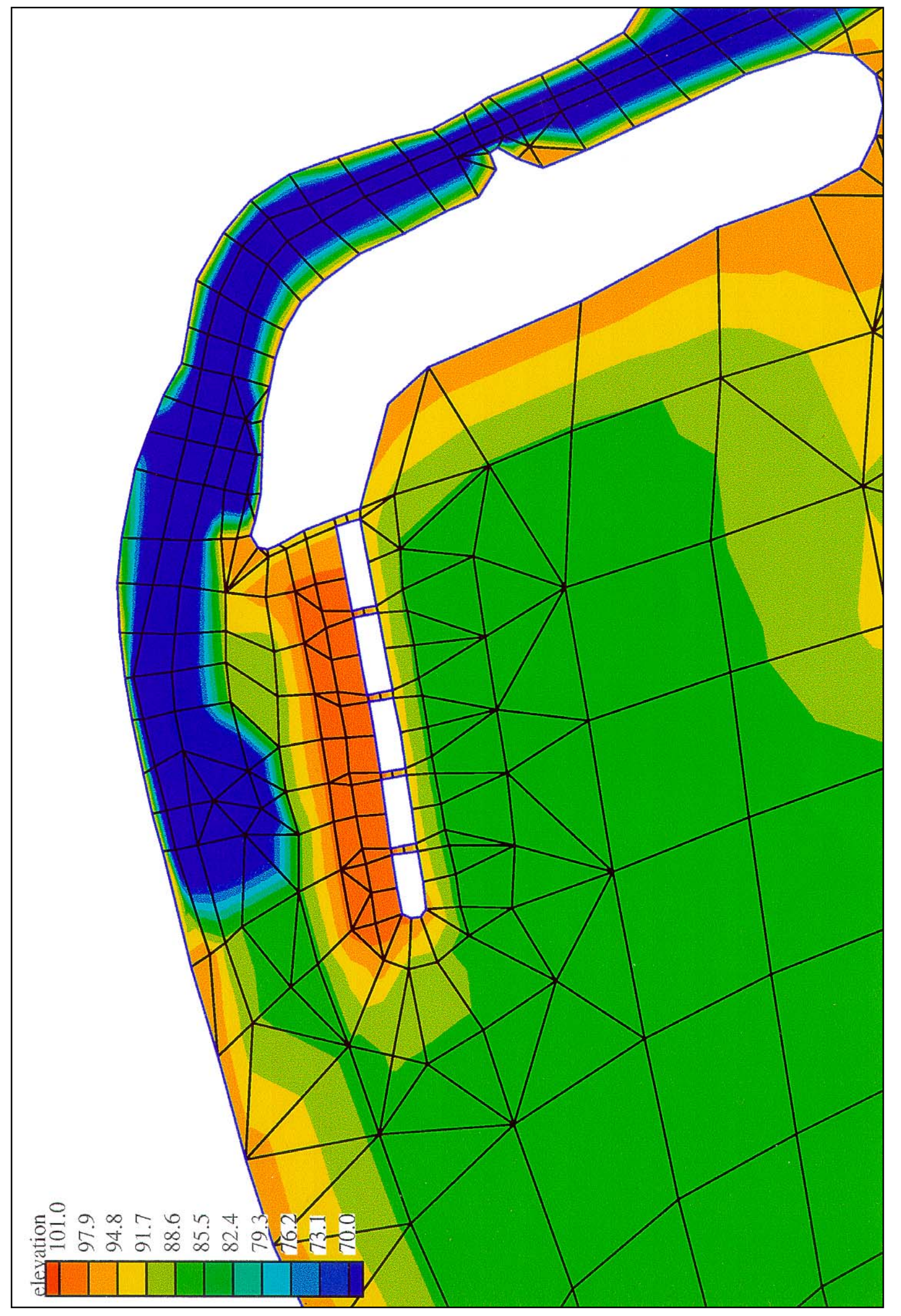

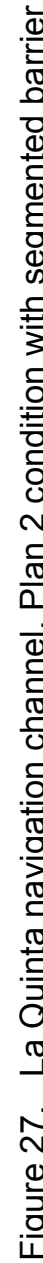




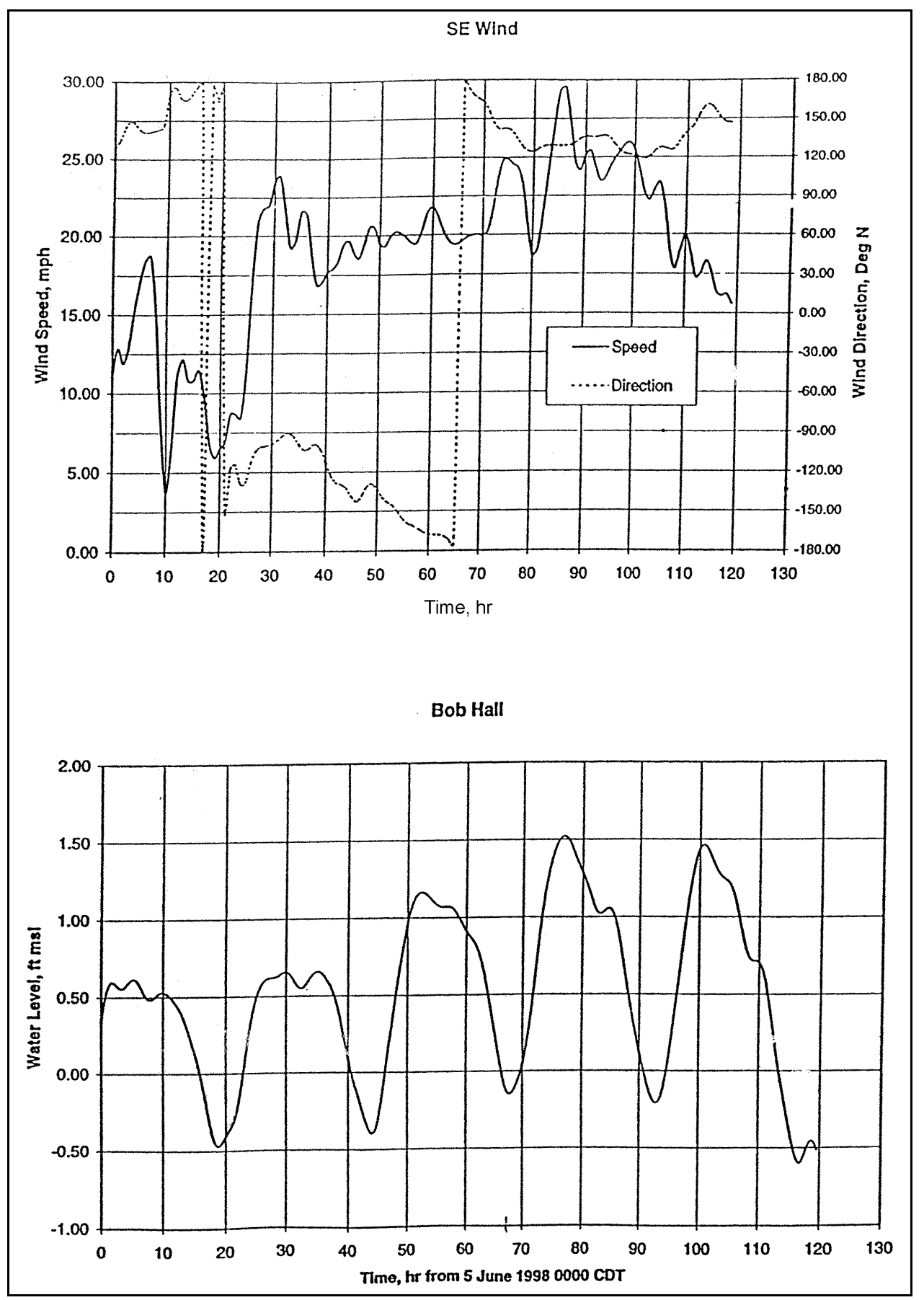

Figure 28. June tides and southeast wind selected for model run (measured at Bob Hall) 


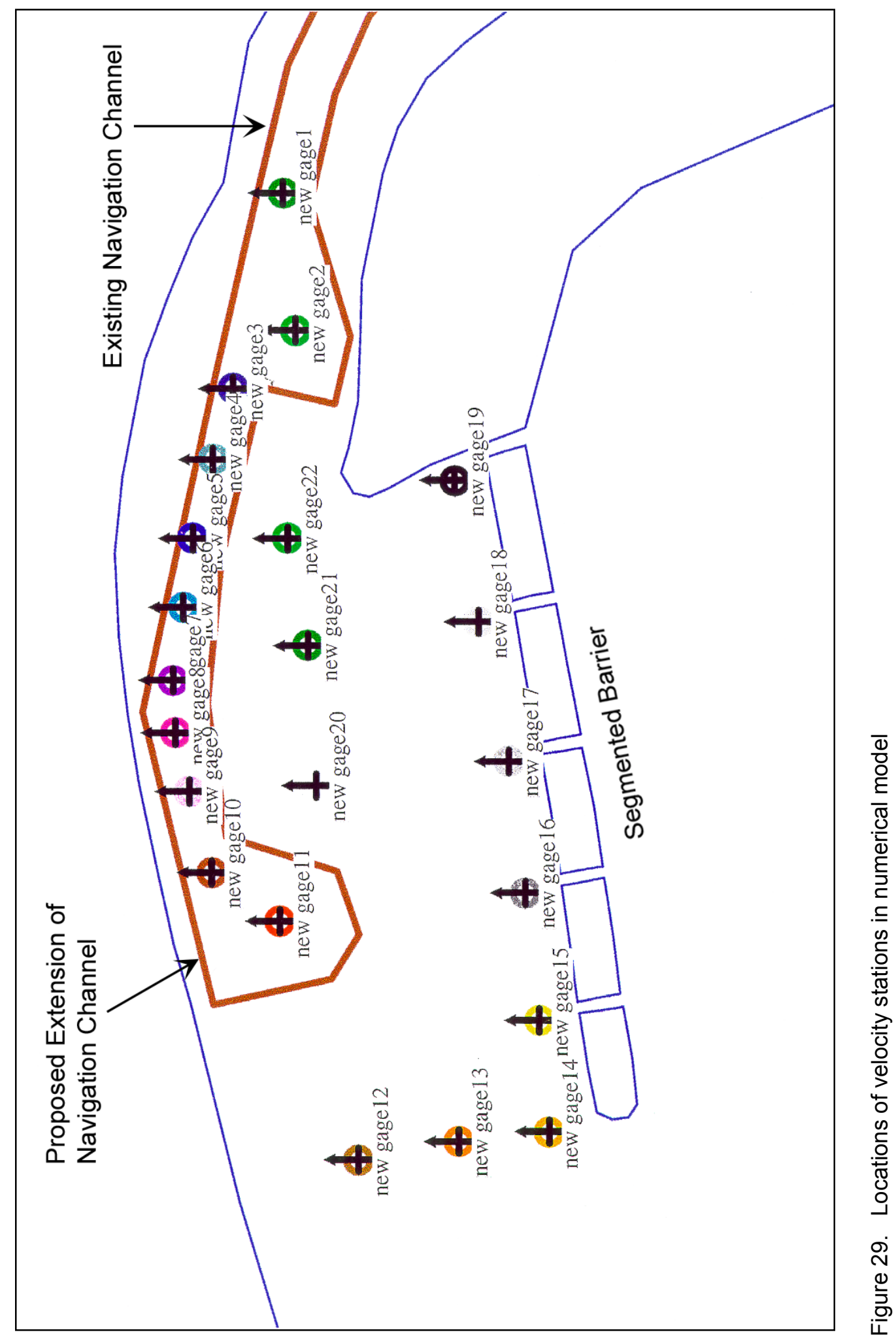




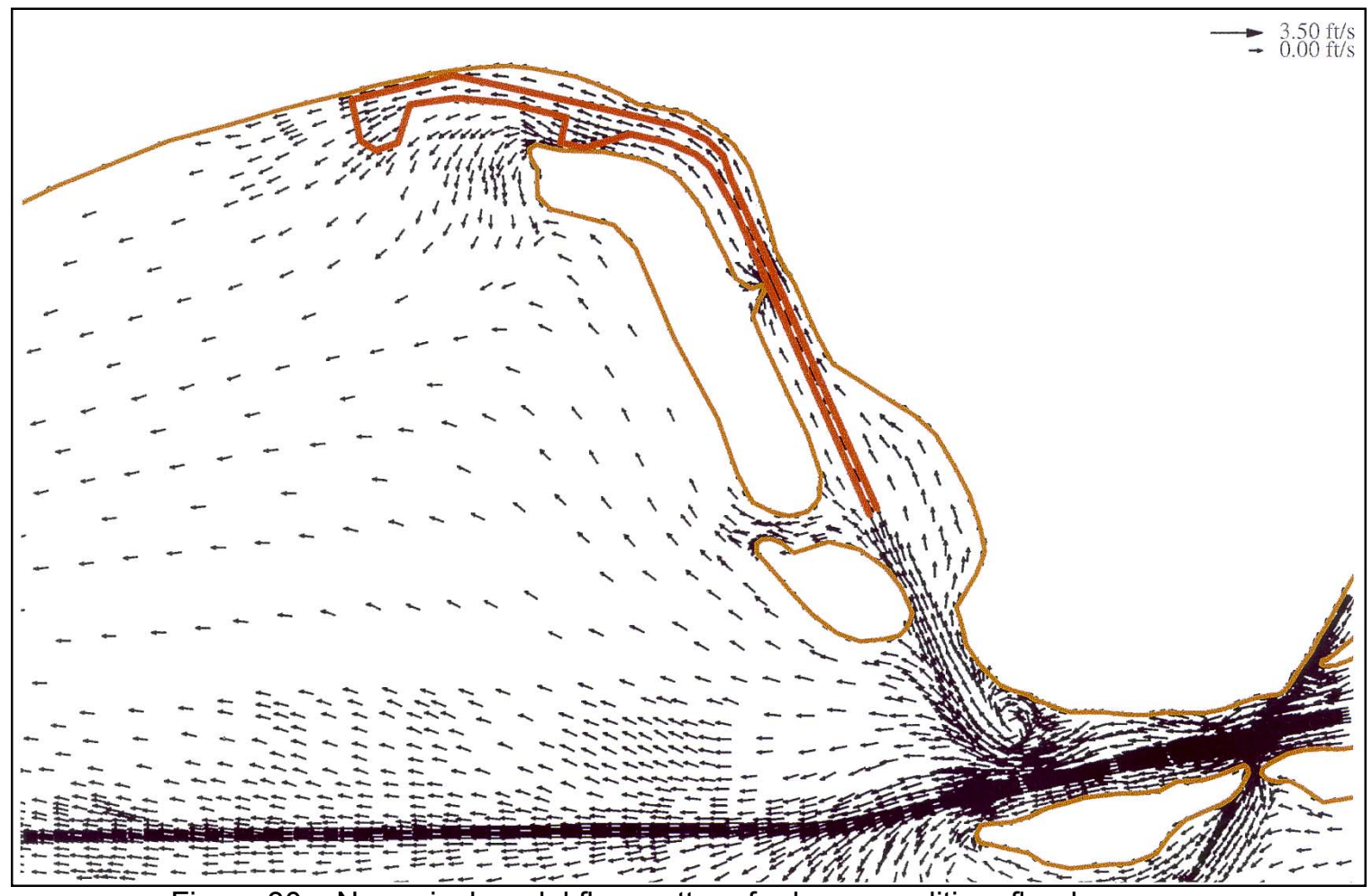

Figure 30. Numerical model flow pattern for base condition, flood

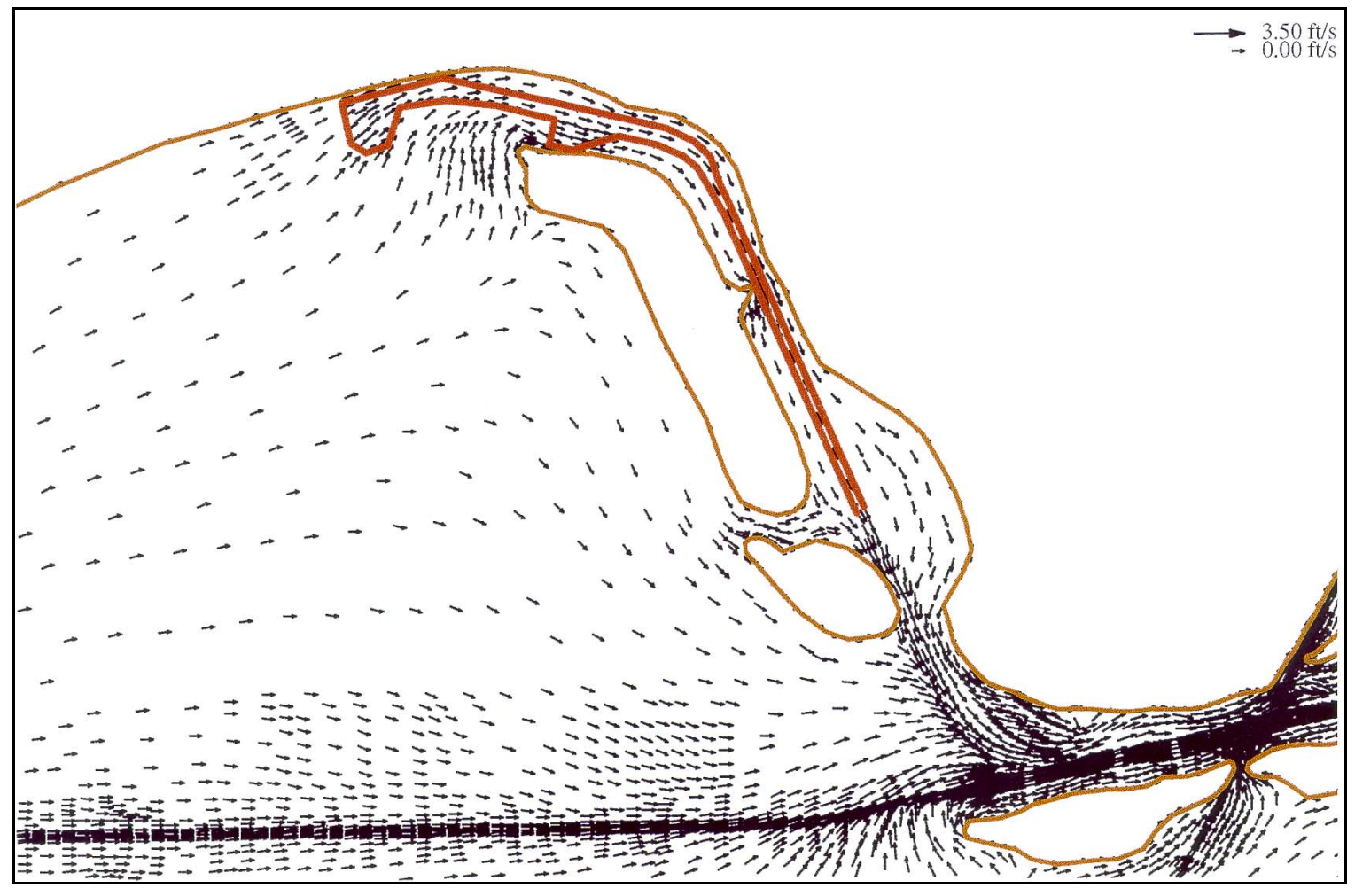

Figure 31. Numerical model flow pattern for base condition, ebb 


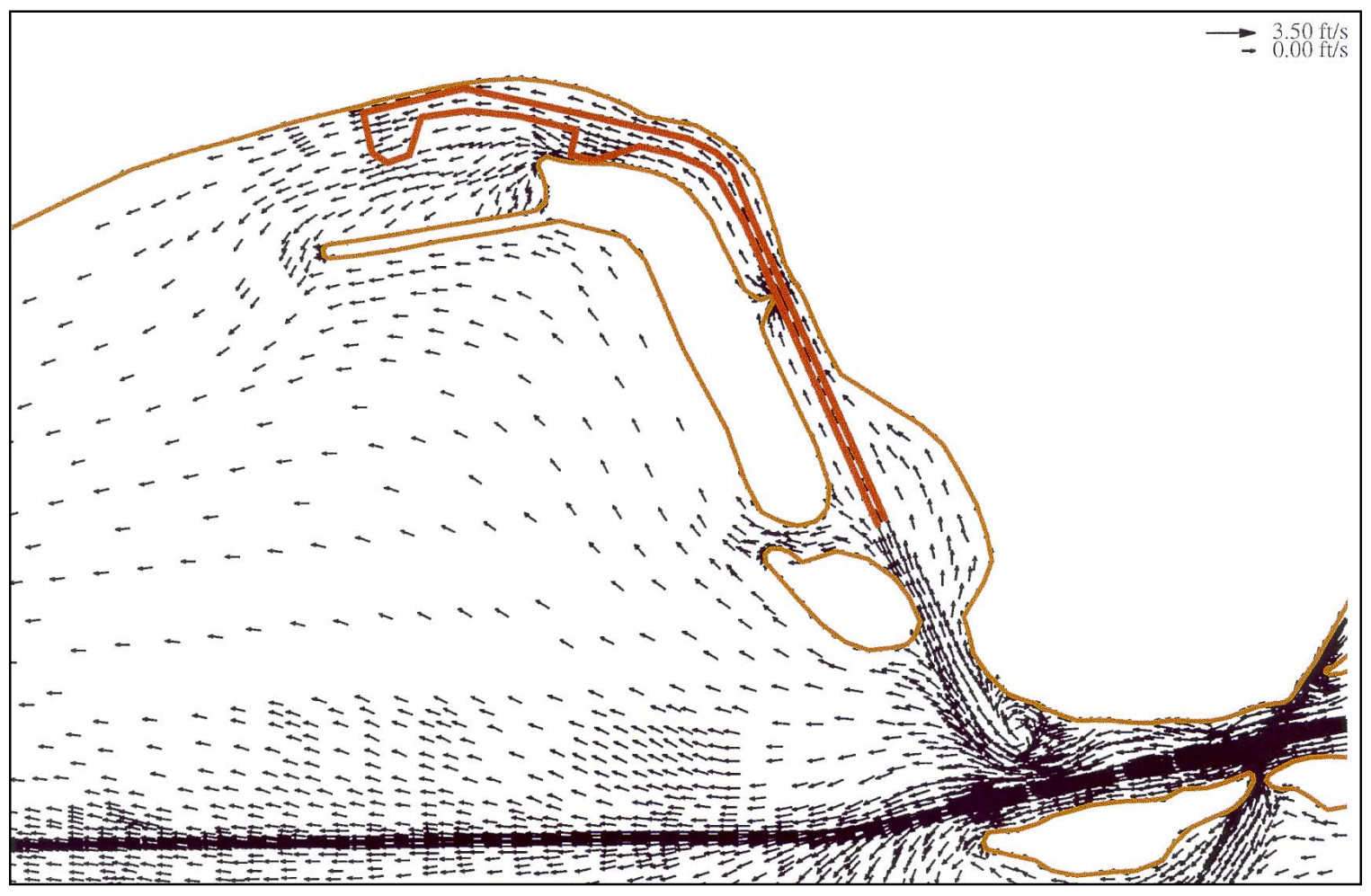

Figure 32. Numerical model flow pattern for Plan 1 (continuous barrier), flood

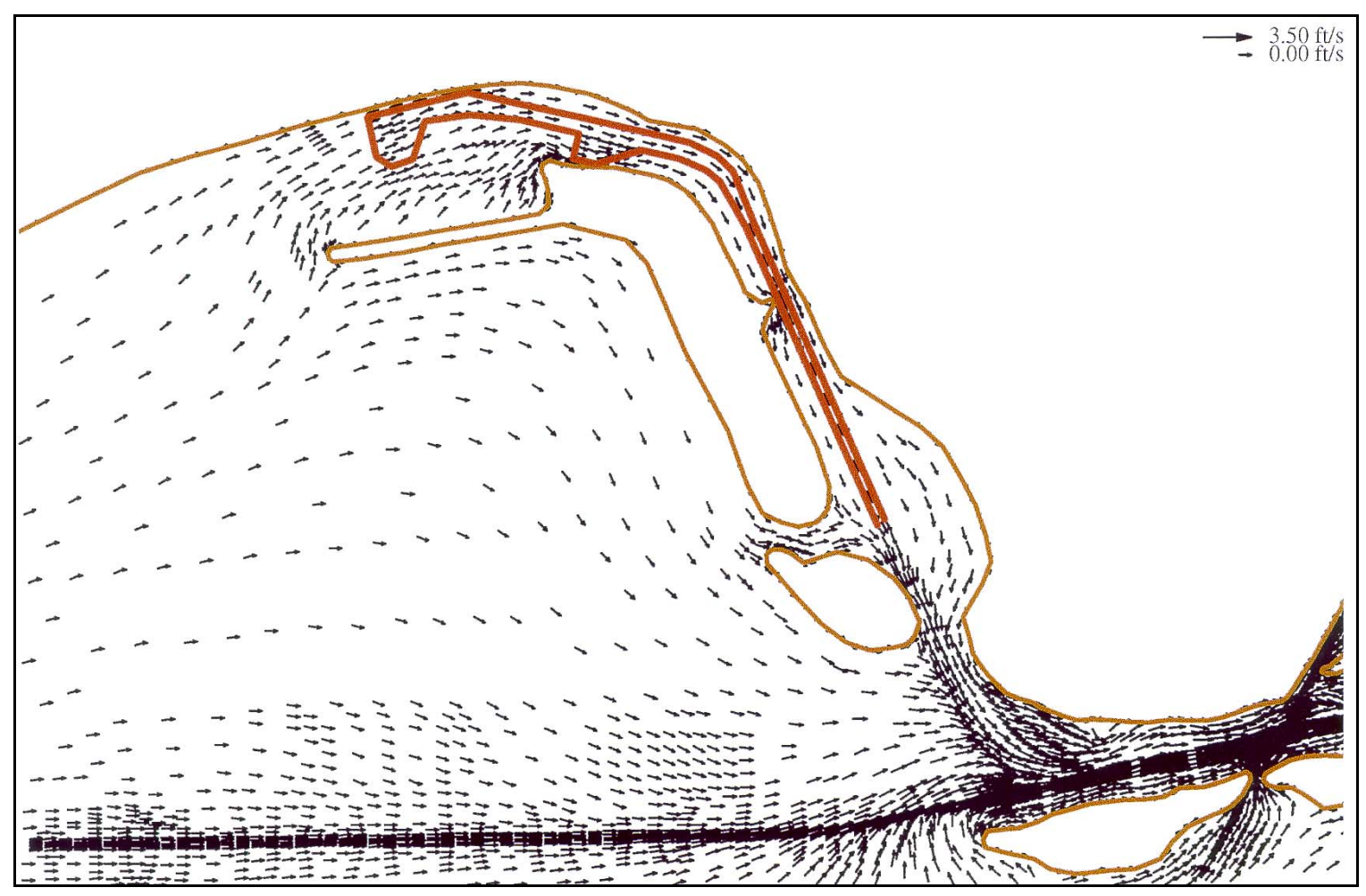

Figure 33. Numerical model flow pattern for Plan 1 (continuous barrier), ebb 


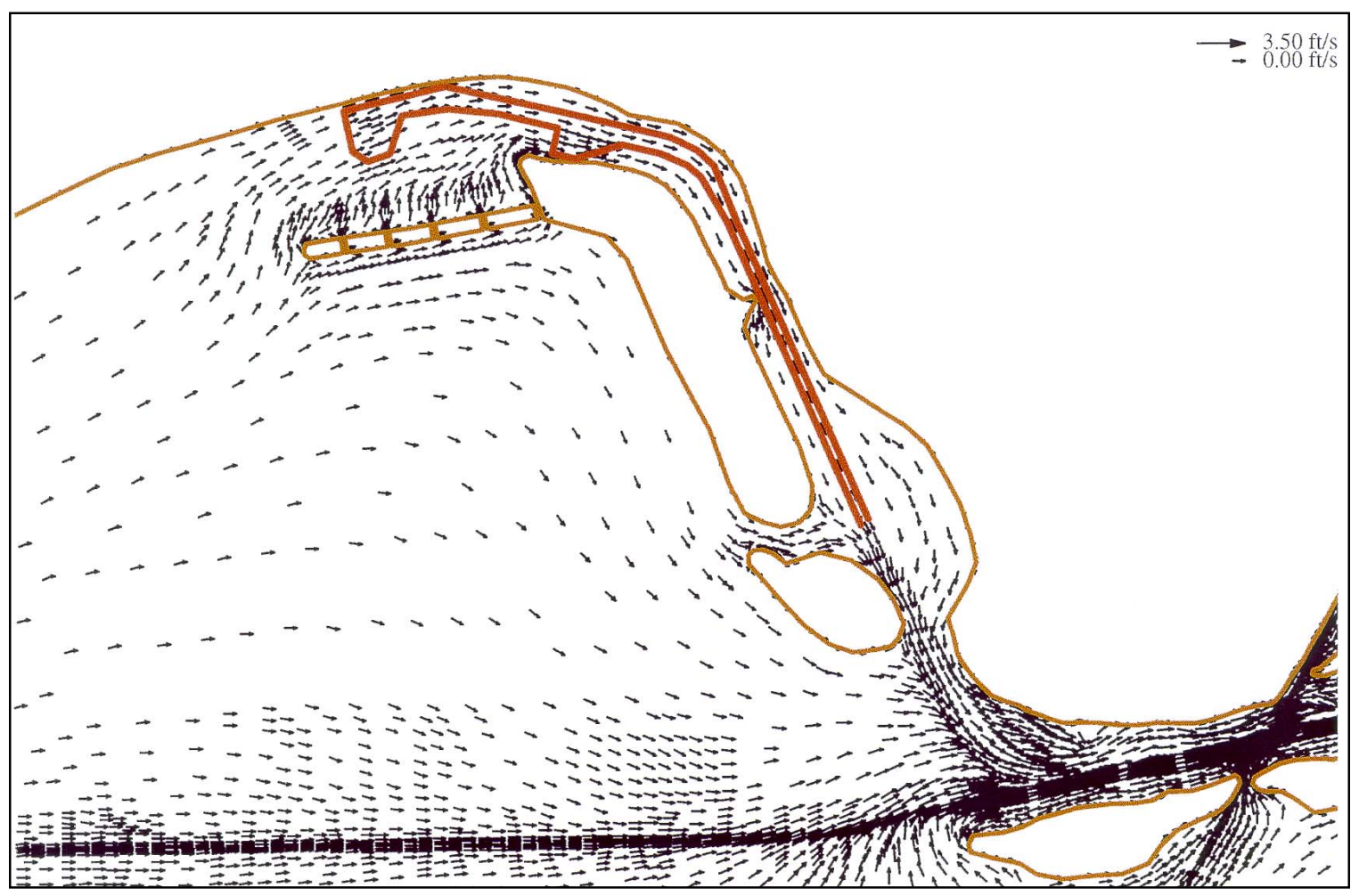

Figure 34. Numerical model flow pattern for Plan 2 (segmented barrier), flood

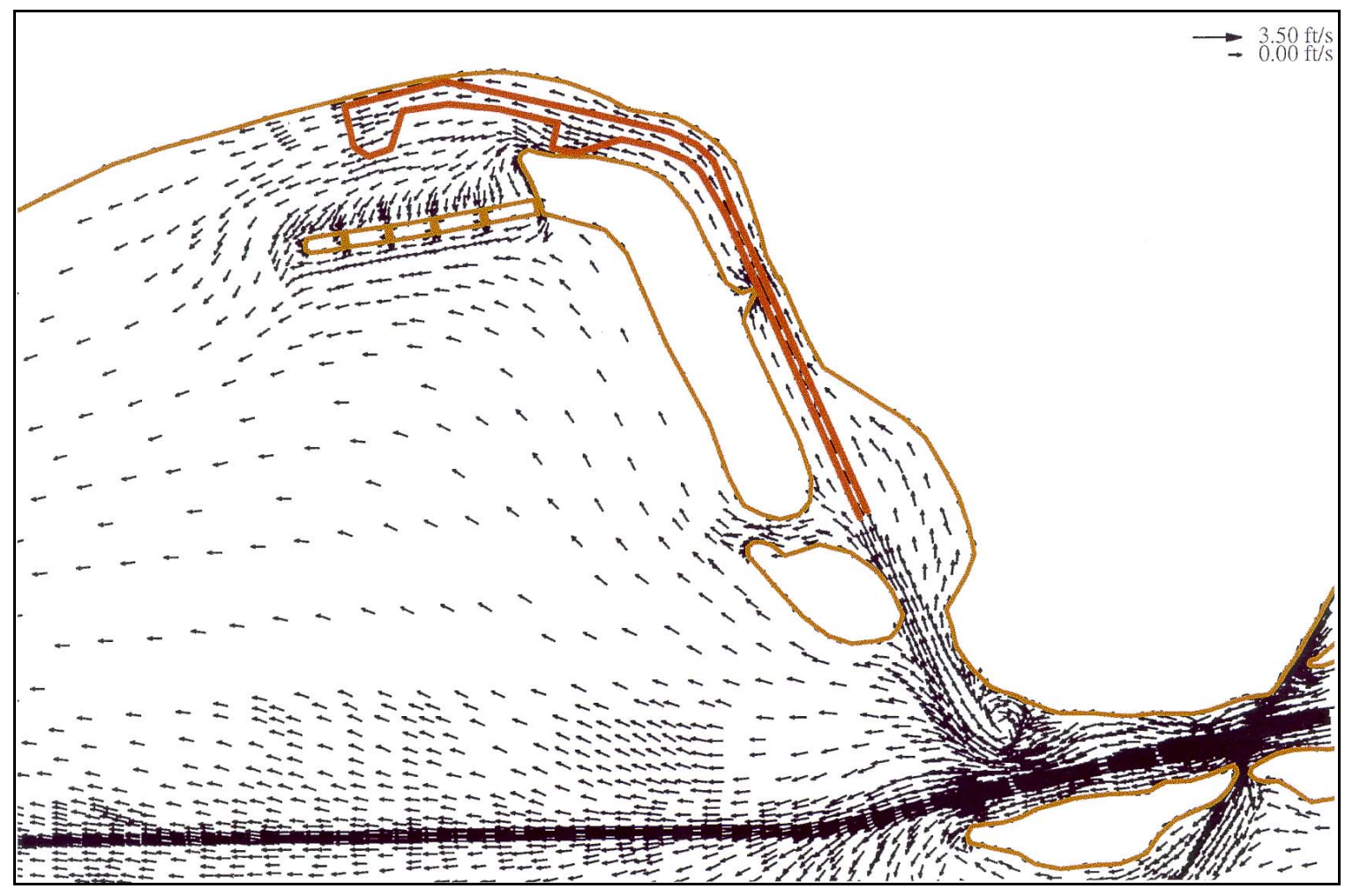

Figure 34. Numerical model flow pattern for Plan 2 (segmented barrier), ebb 


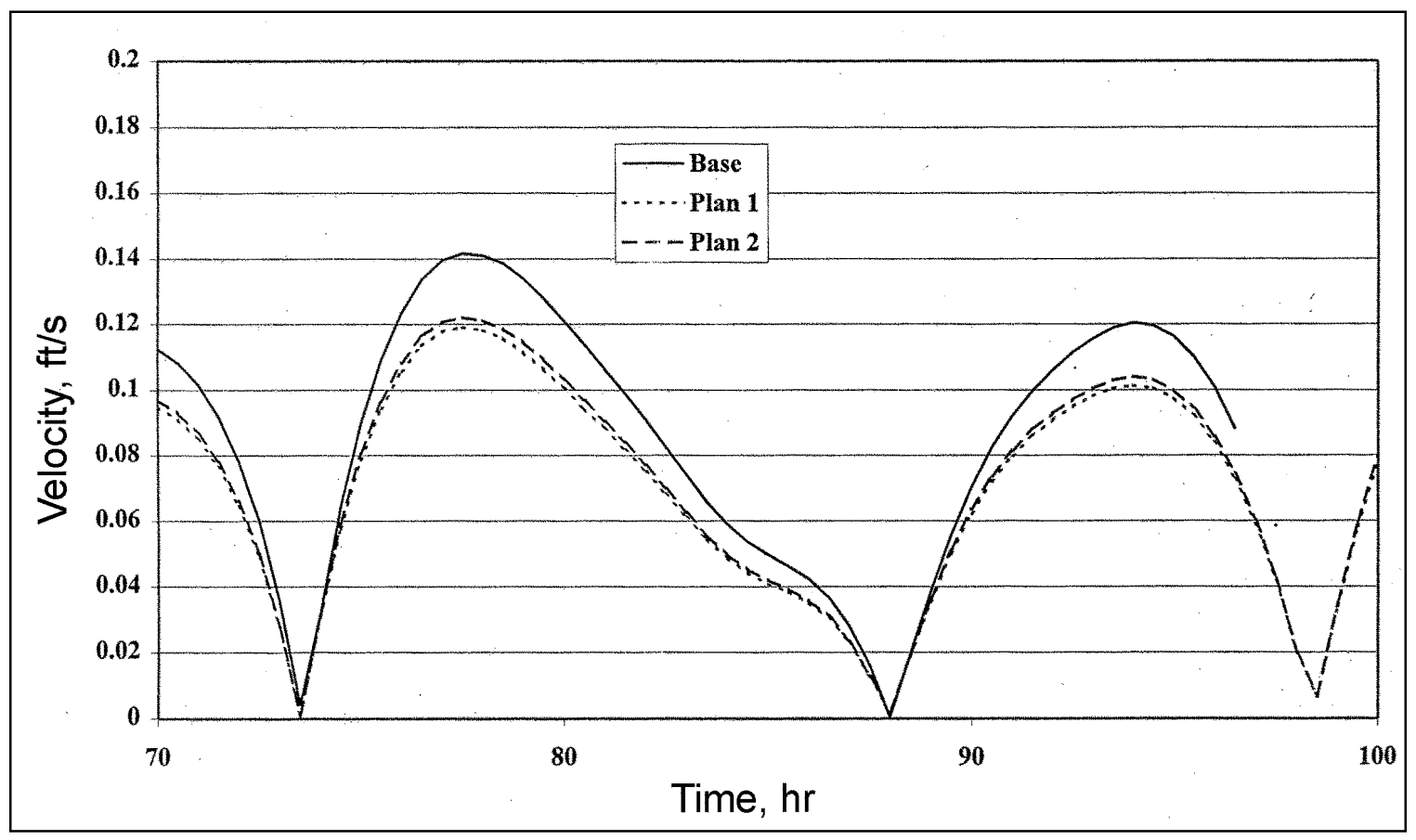

Figure 36. Velocity at station 1 obtained on numerical model

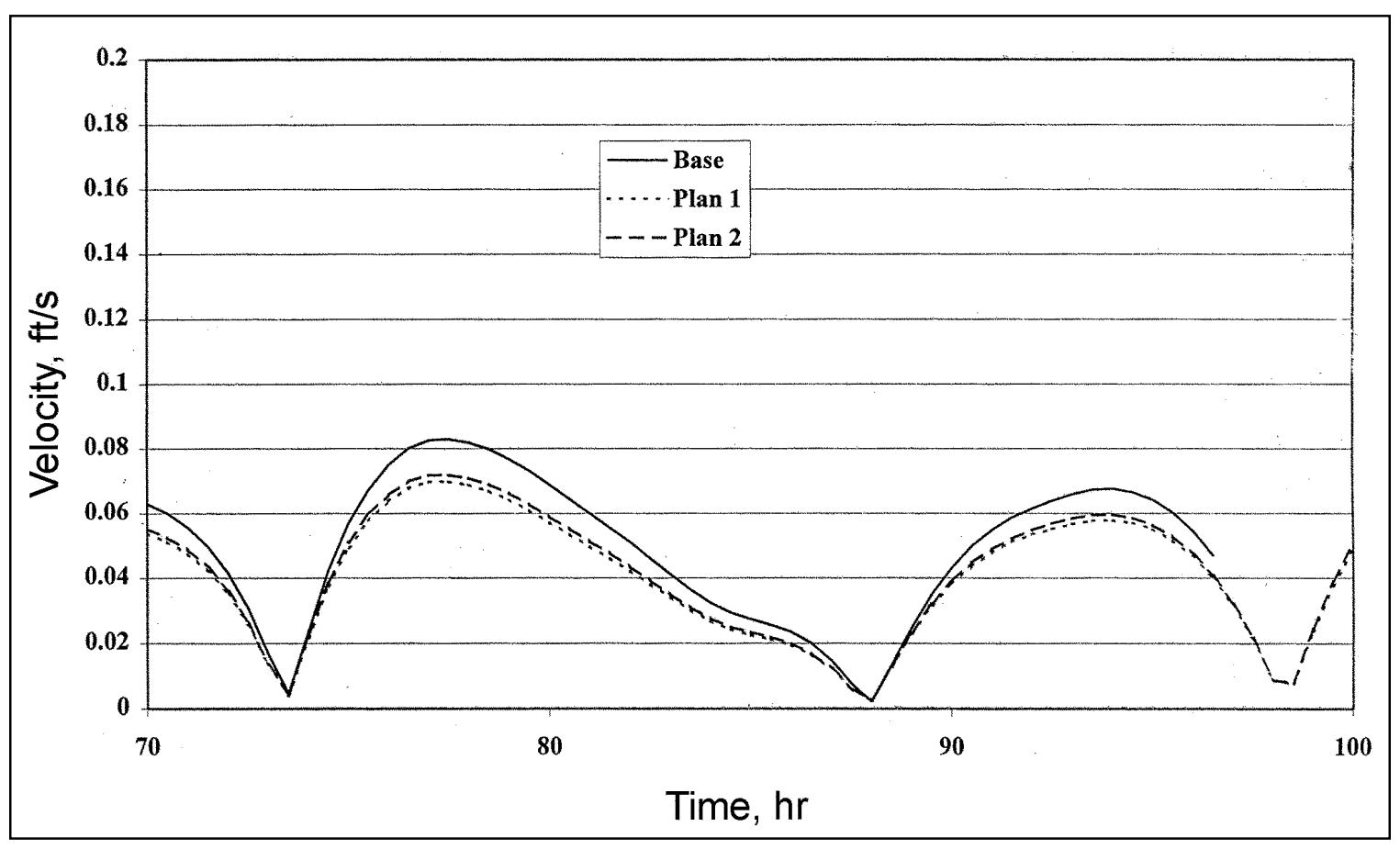

Figure $37 . \quad$ Velocity at station 2 obtained on numerical model 


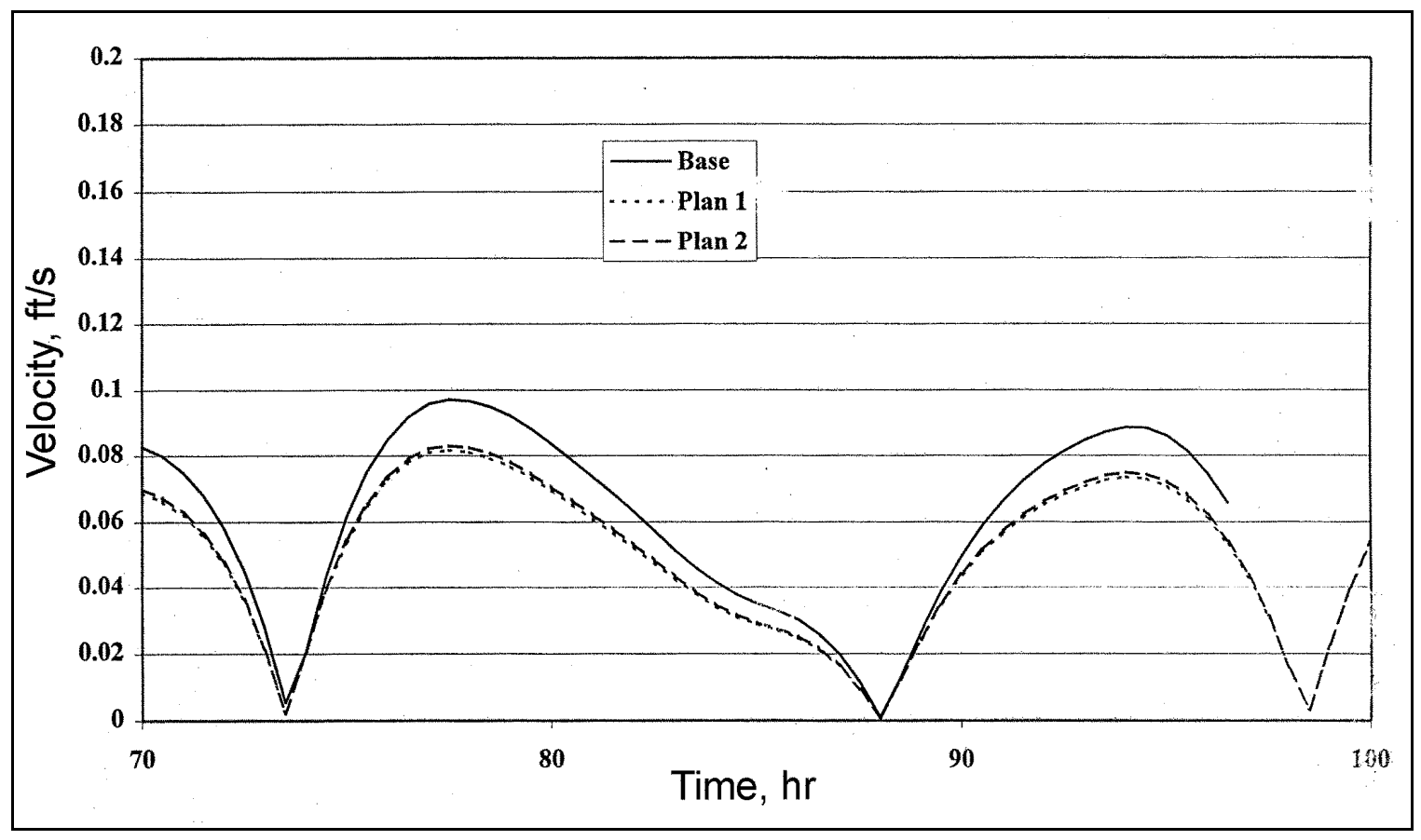

Figure 38. Velocity at station 3 obtained on numerical model

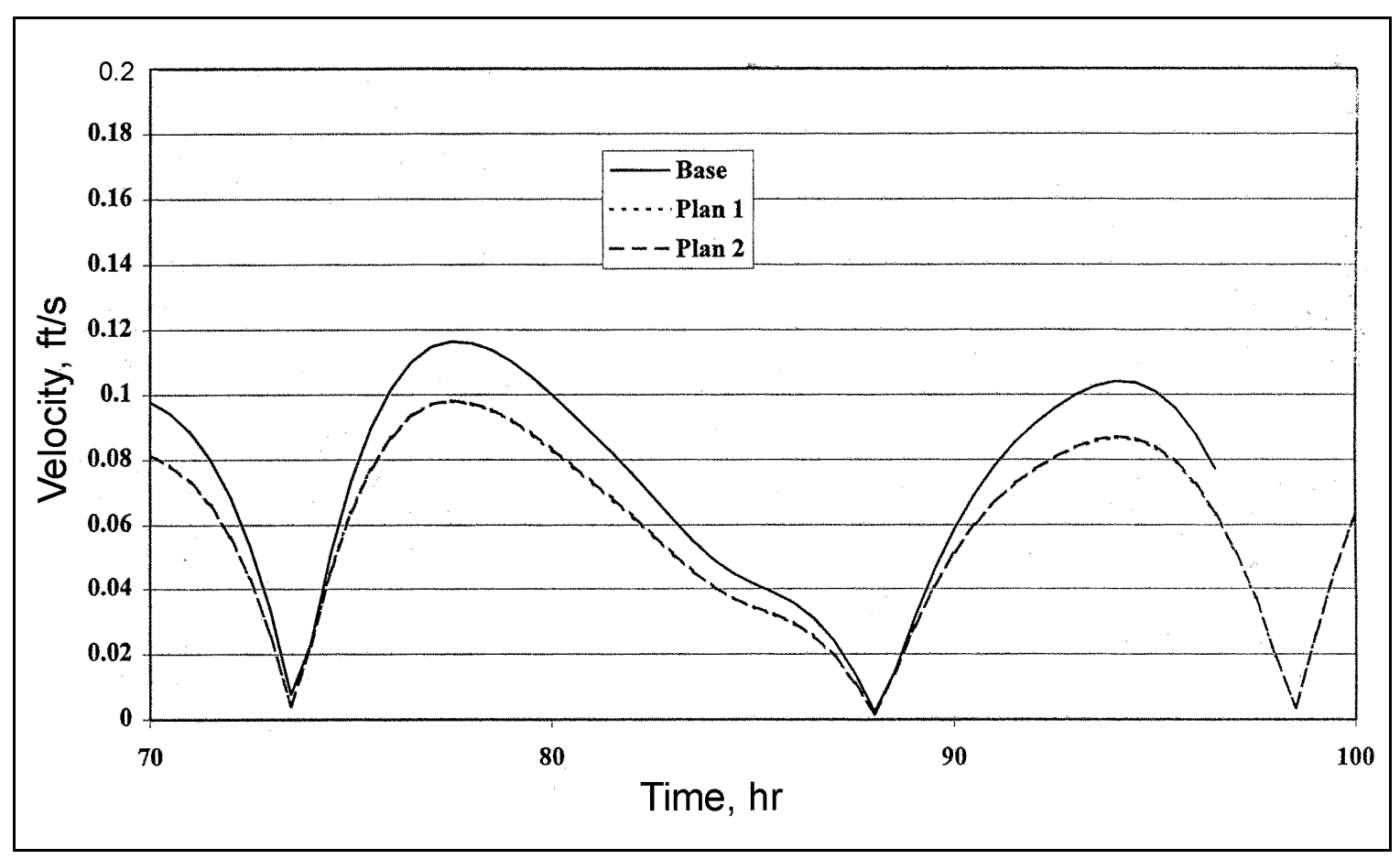

Figure 39. Velocity at station 4 obtained on numerical model 


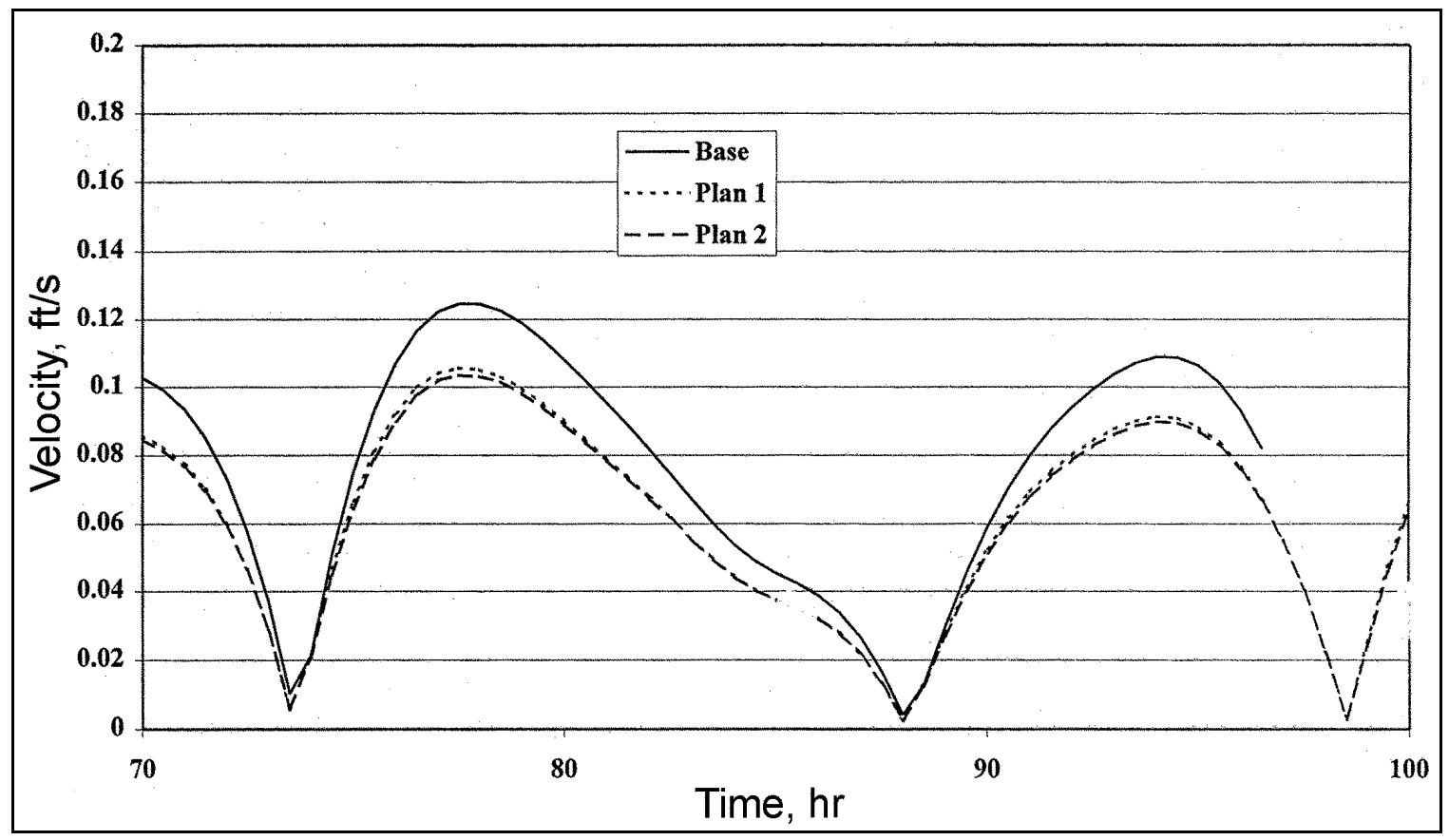

Figure 40 . Velocity at station 5 obtained on numerical model

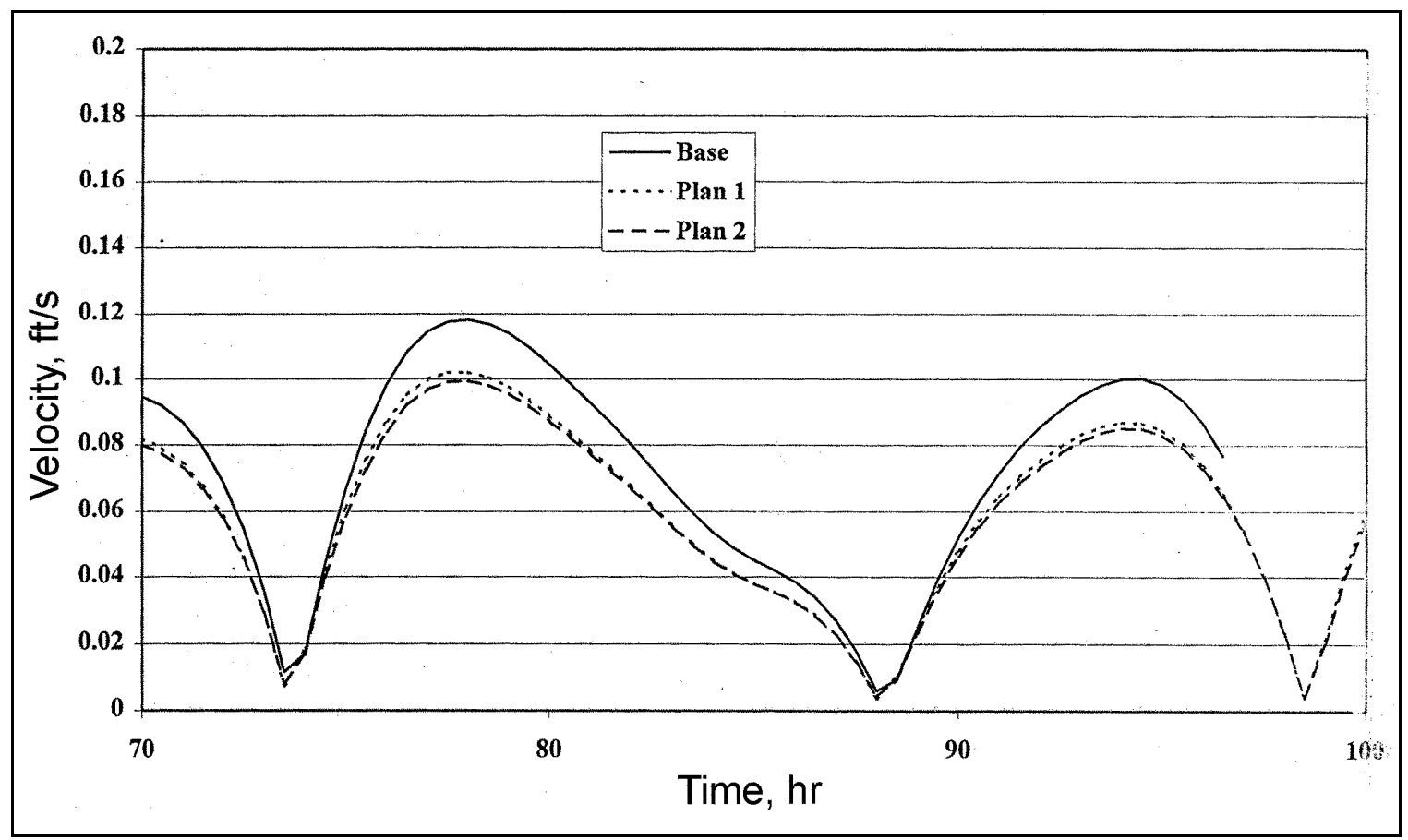

Figure 41 . Velocity at station 6 obtained on numerical model 


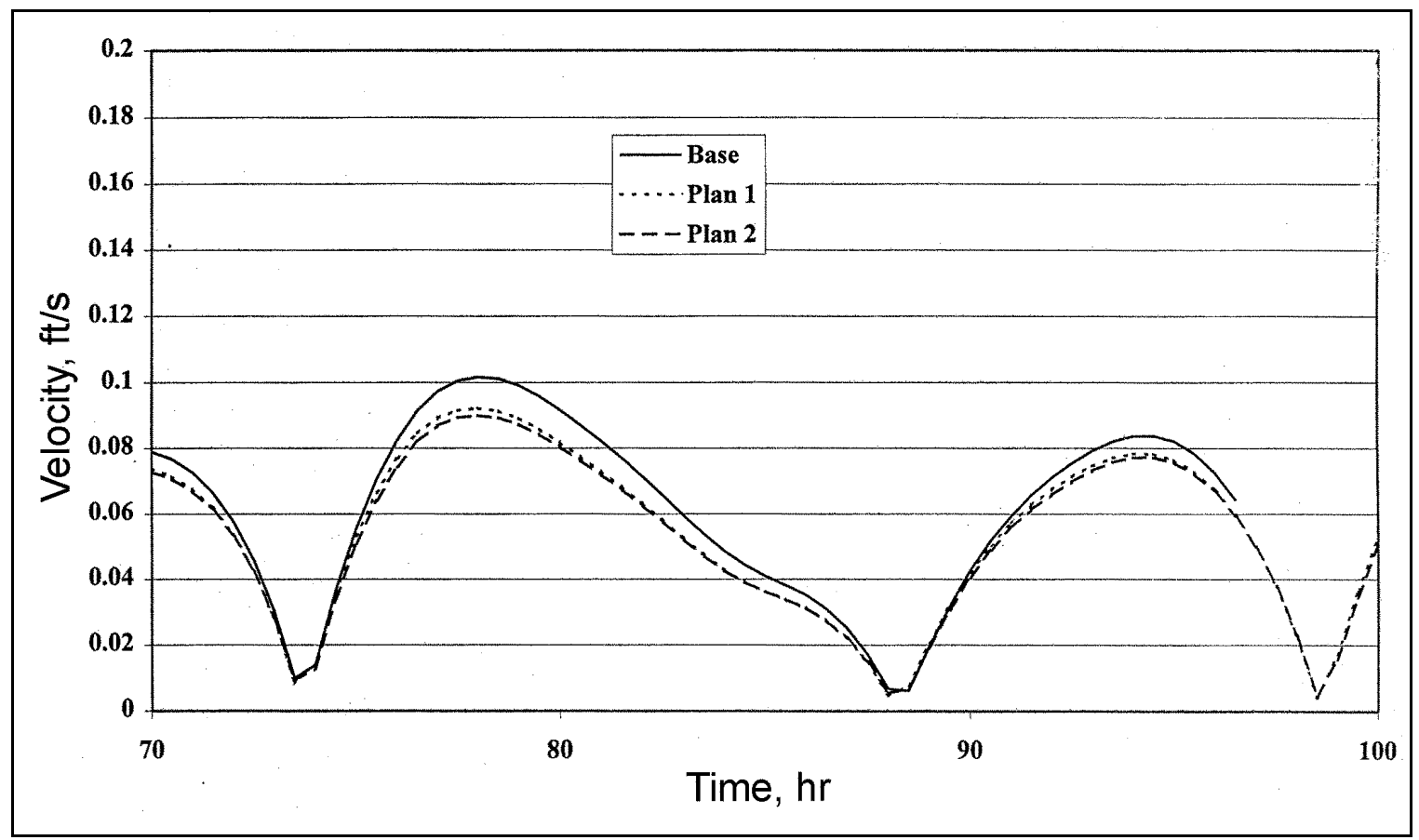

Figure 42. Velocity at station 7 obtained on numerical model

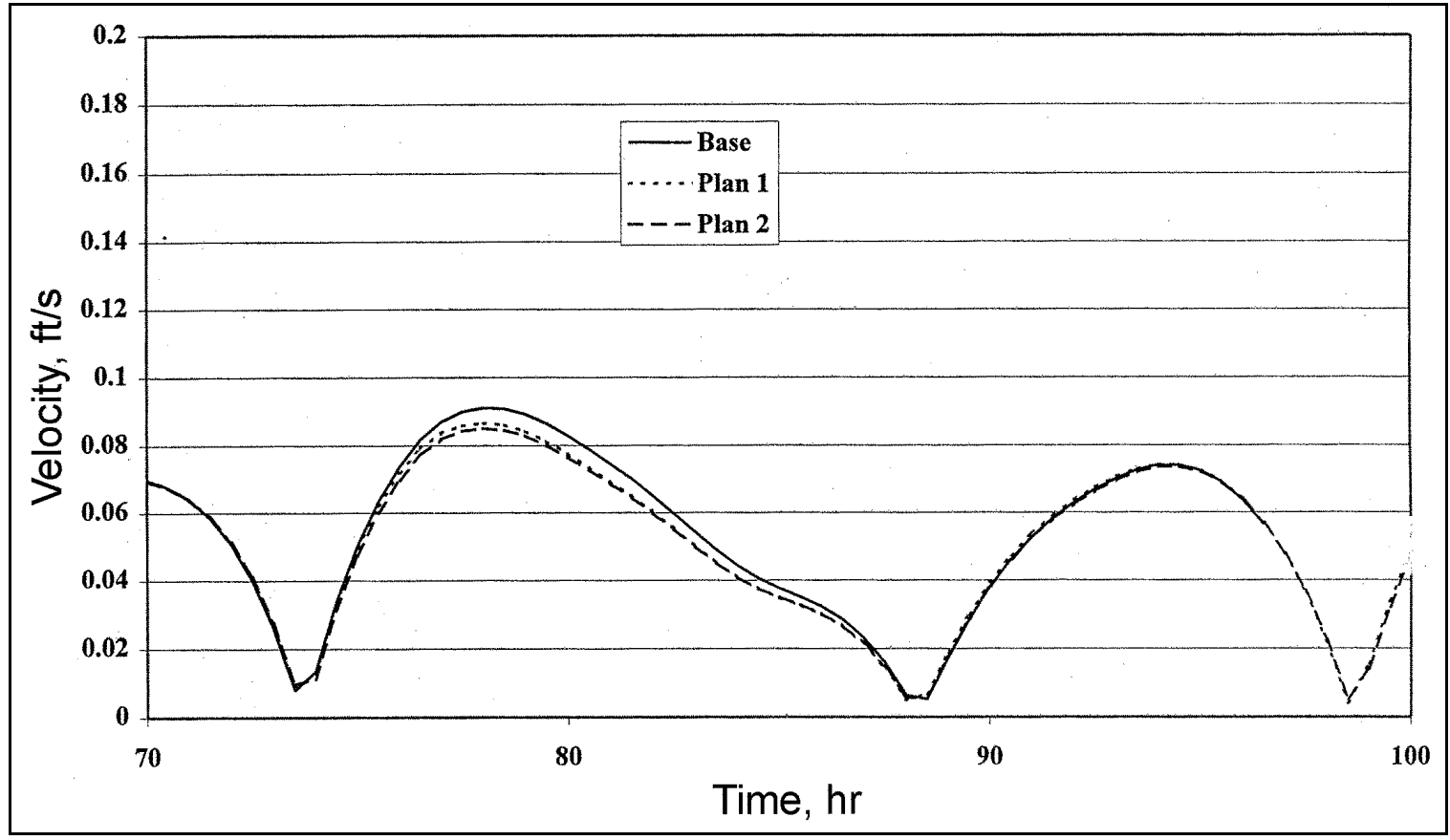

Figure 43. Velocity at station 8 obtained on numerical model 


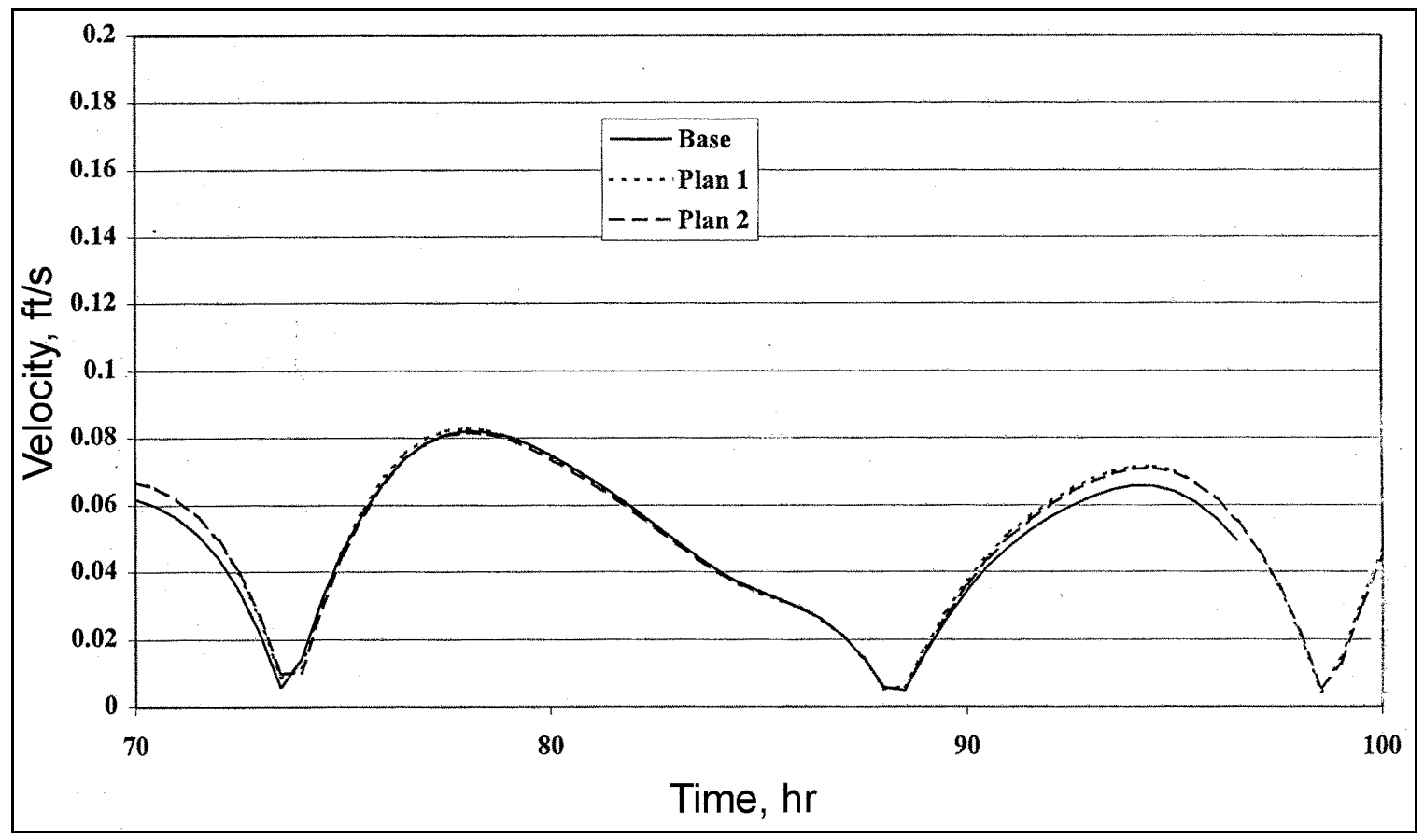

Figure 44. Velocity at station 9 obtained on numerical model

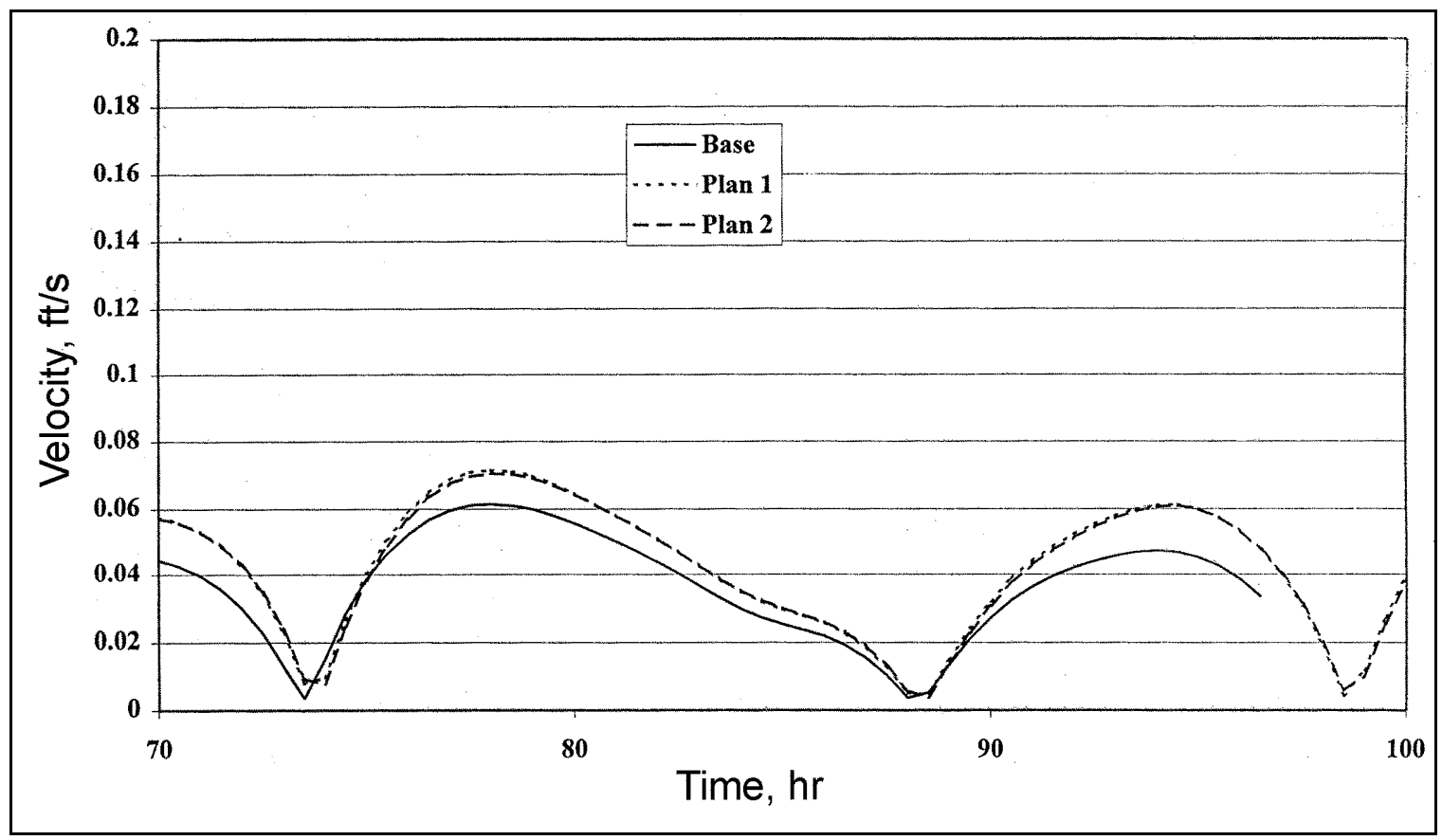

Figure 45. Velocity at station 10 obtained on numerical model 


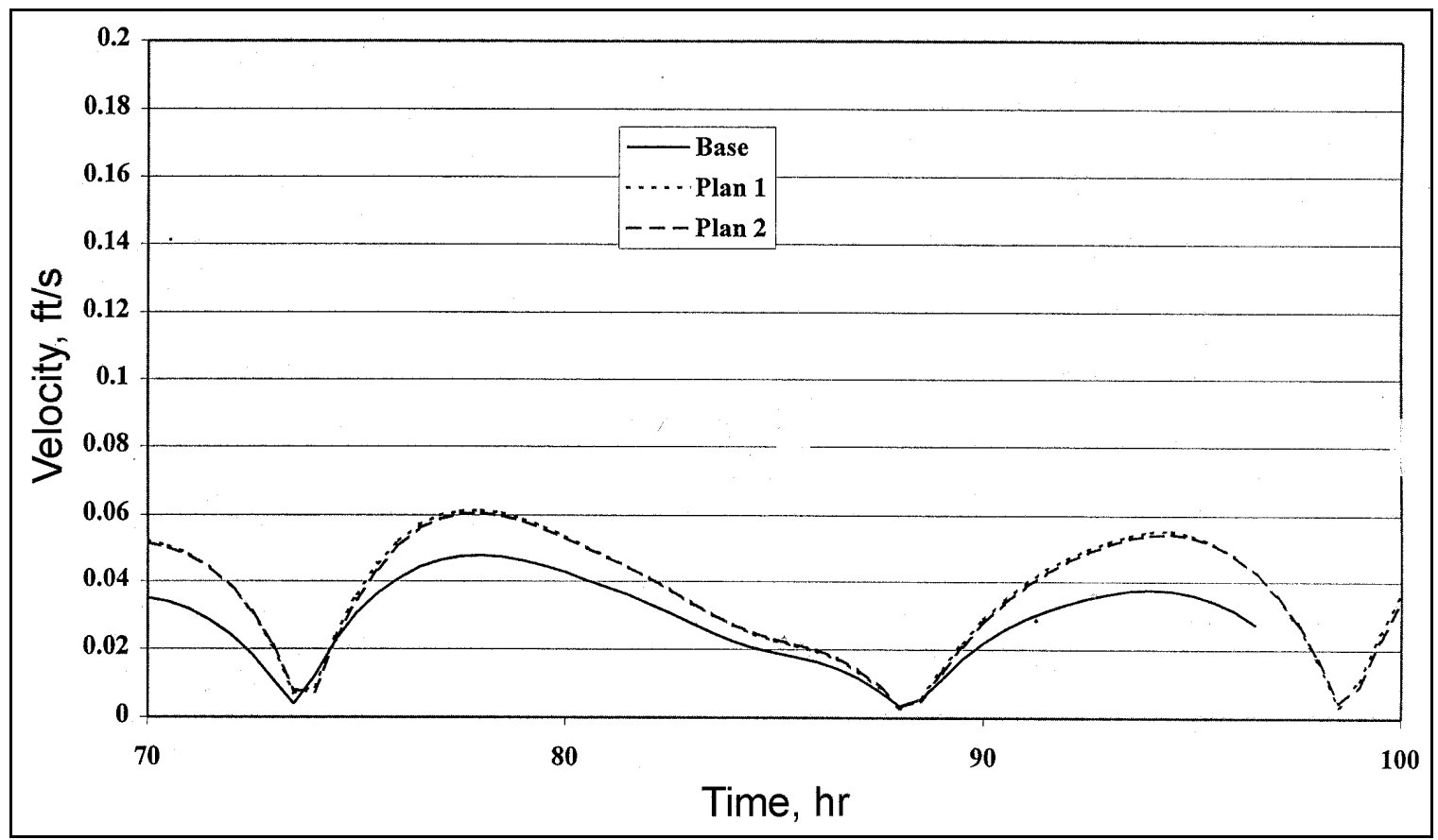

Figure 46. Velocity at station 11 obtained on numerical model

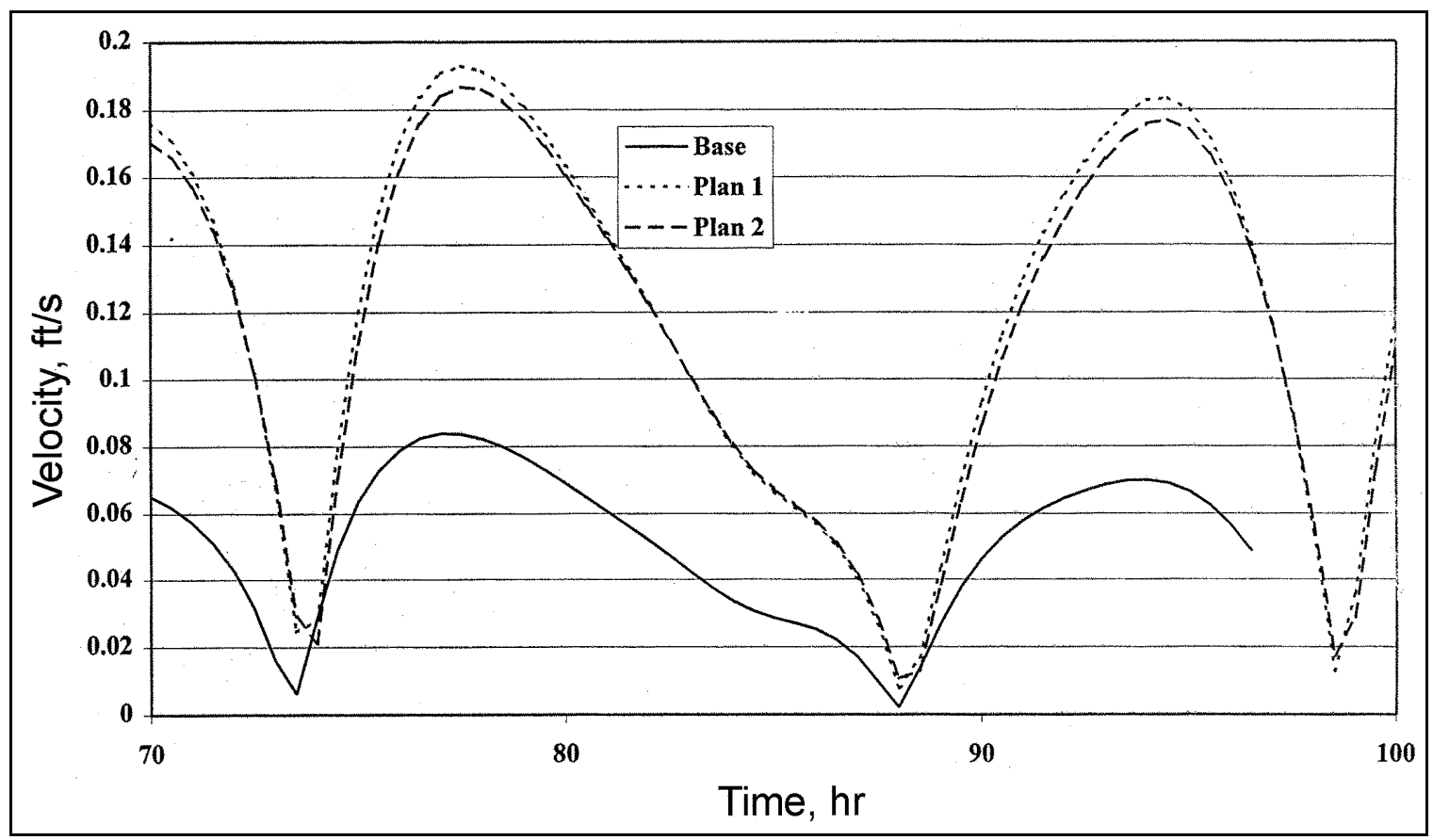

Figure $47 . \quad$ Velocity at station 12 obtained on numerical model 


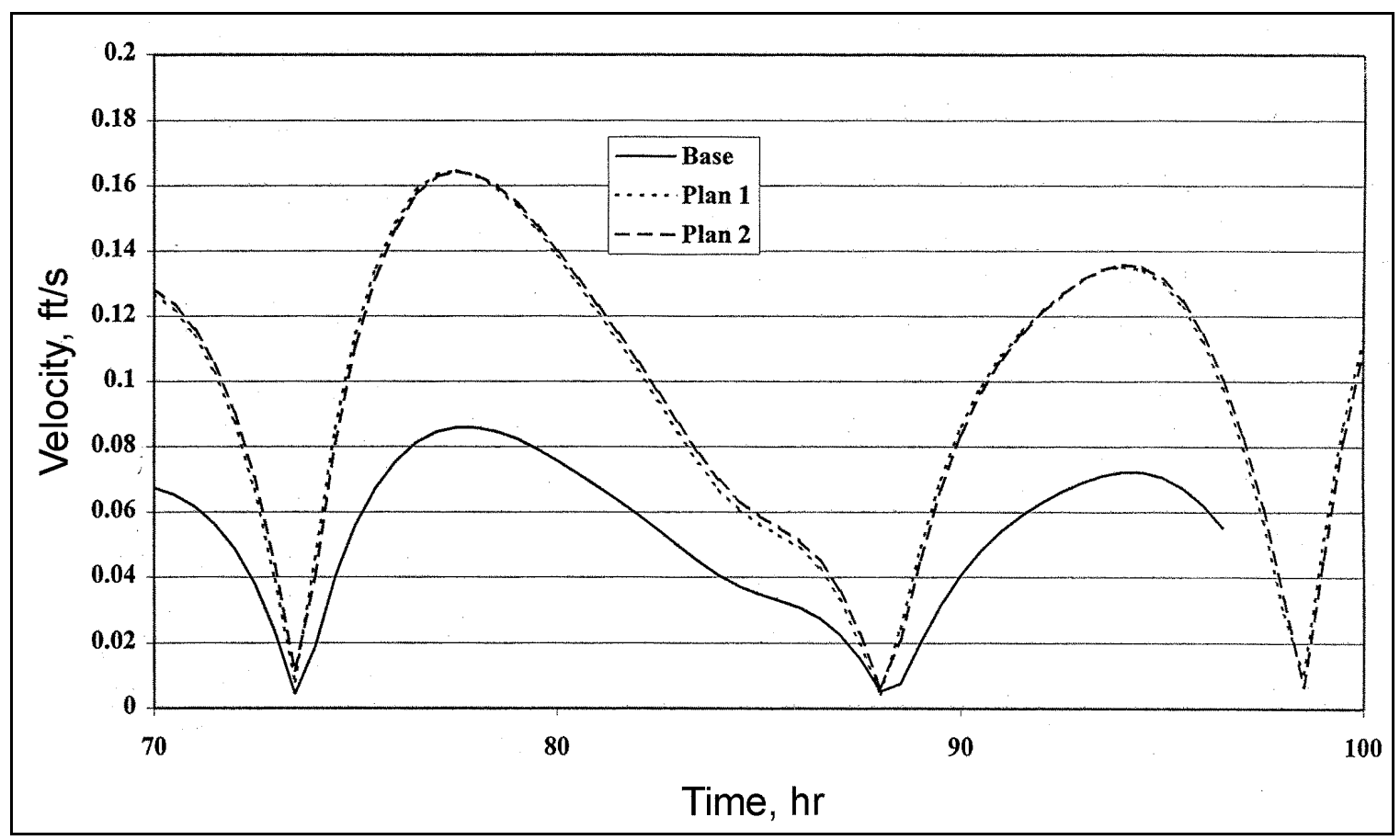

Figure 48. Velocity at station 13 obtained on numerical model

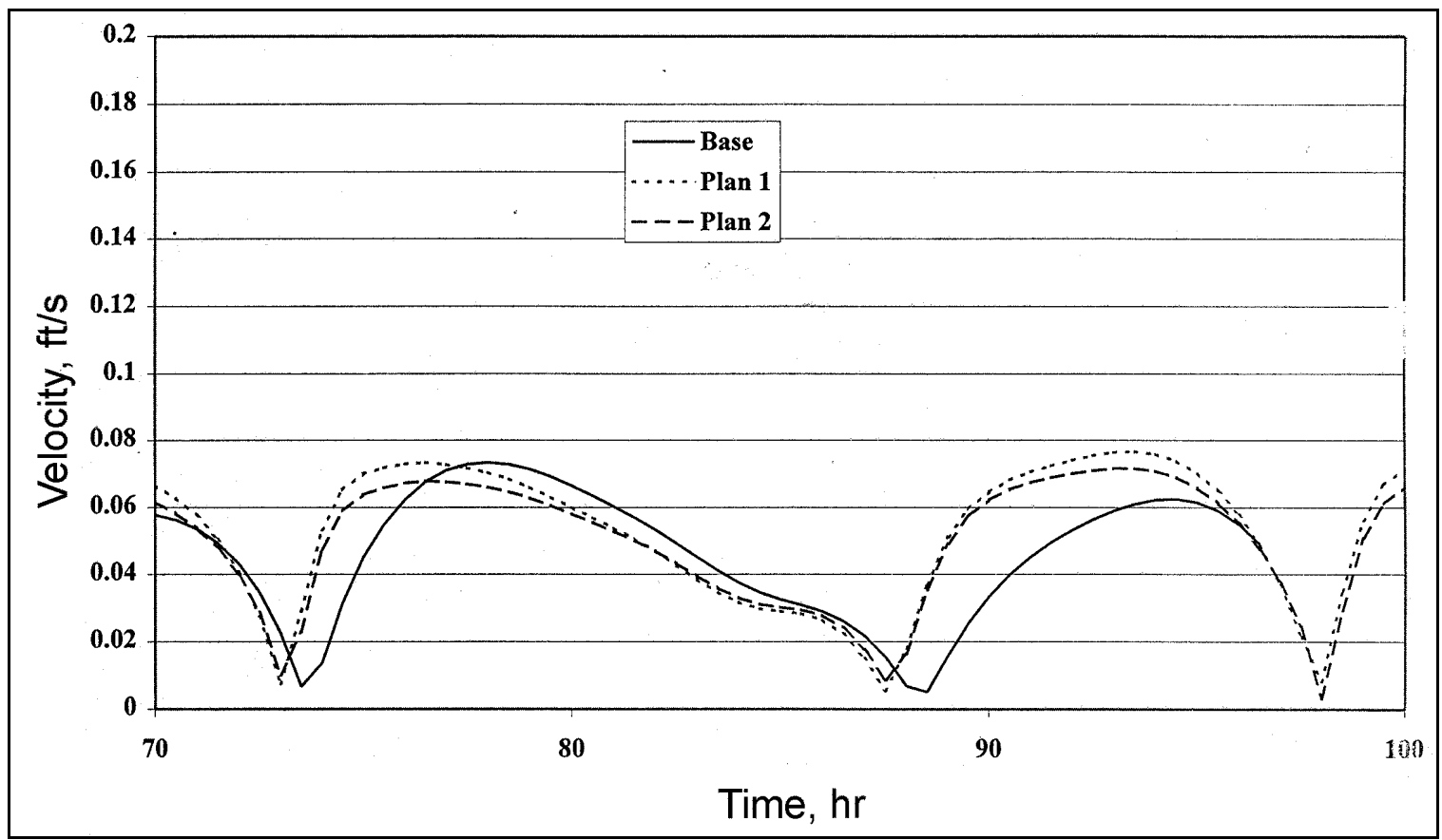

Figure 49. Velocity at station 14 obtained on numerical model 


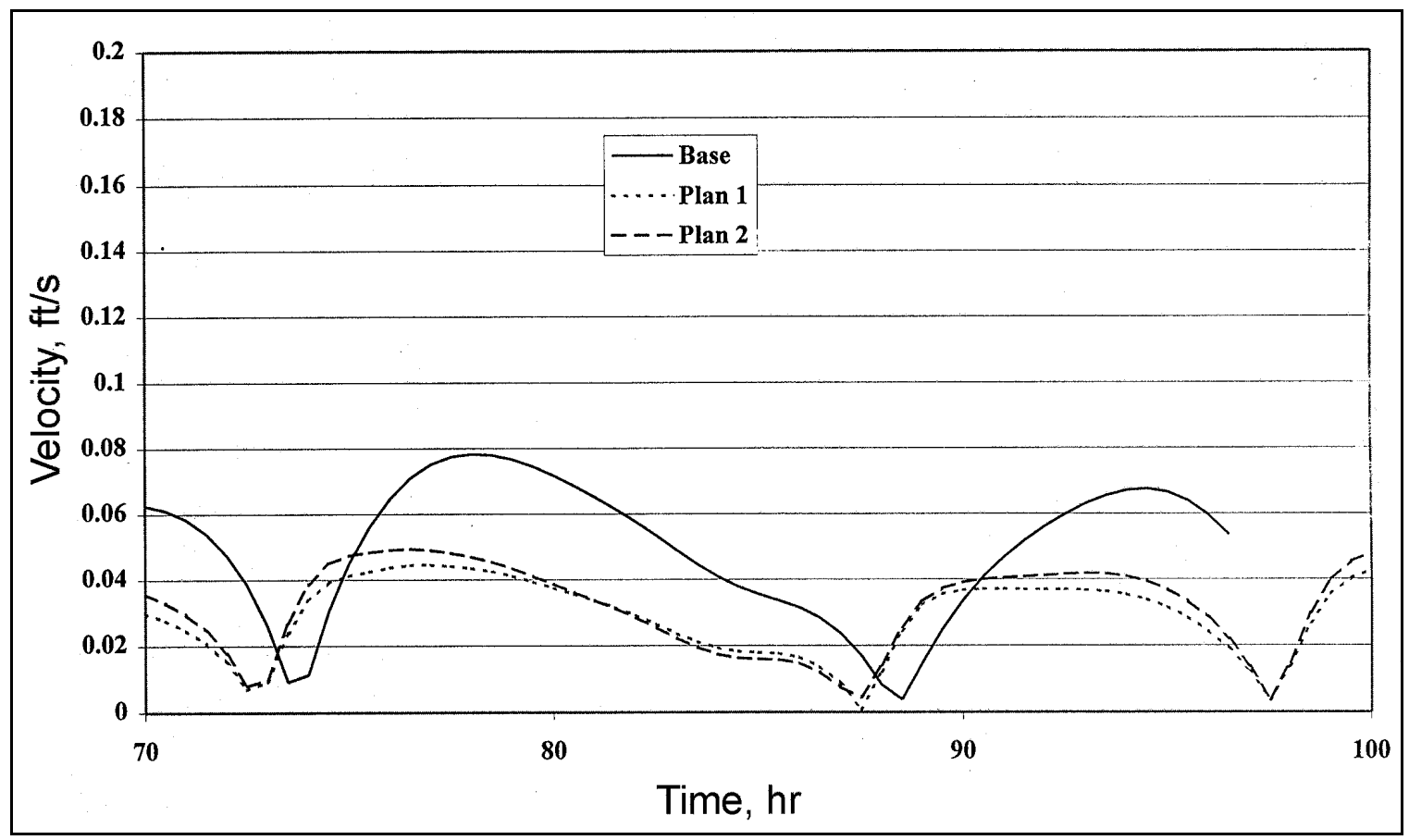

Figure 50. Velocity at station 15 obtained on numerical model

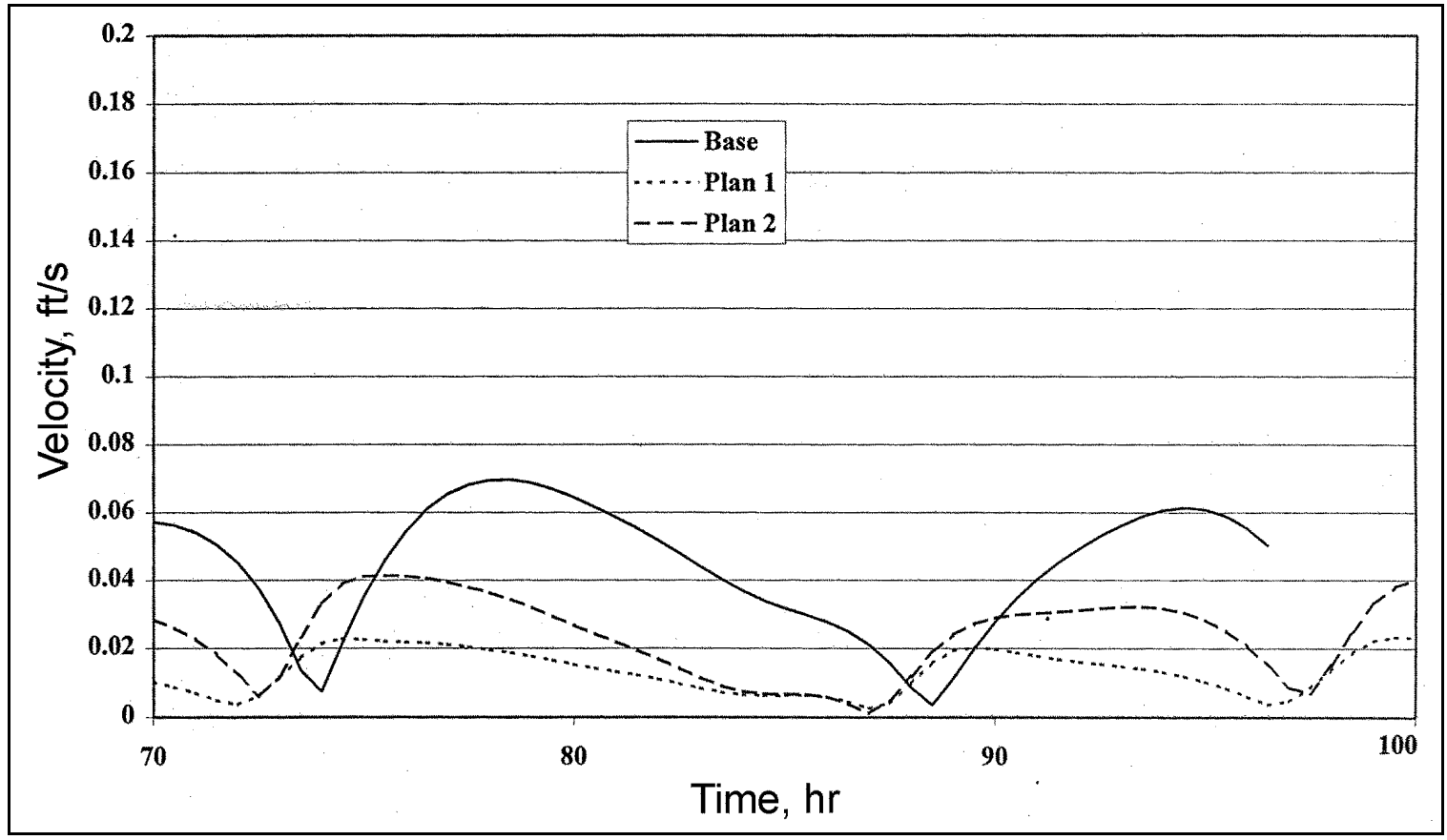

Figure 51. Velocity at station 16 obtained on numerical model 


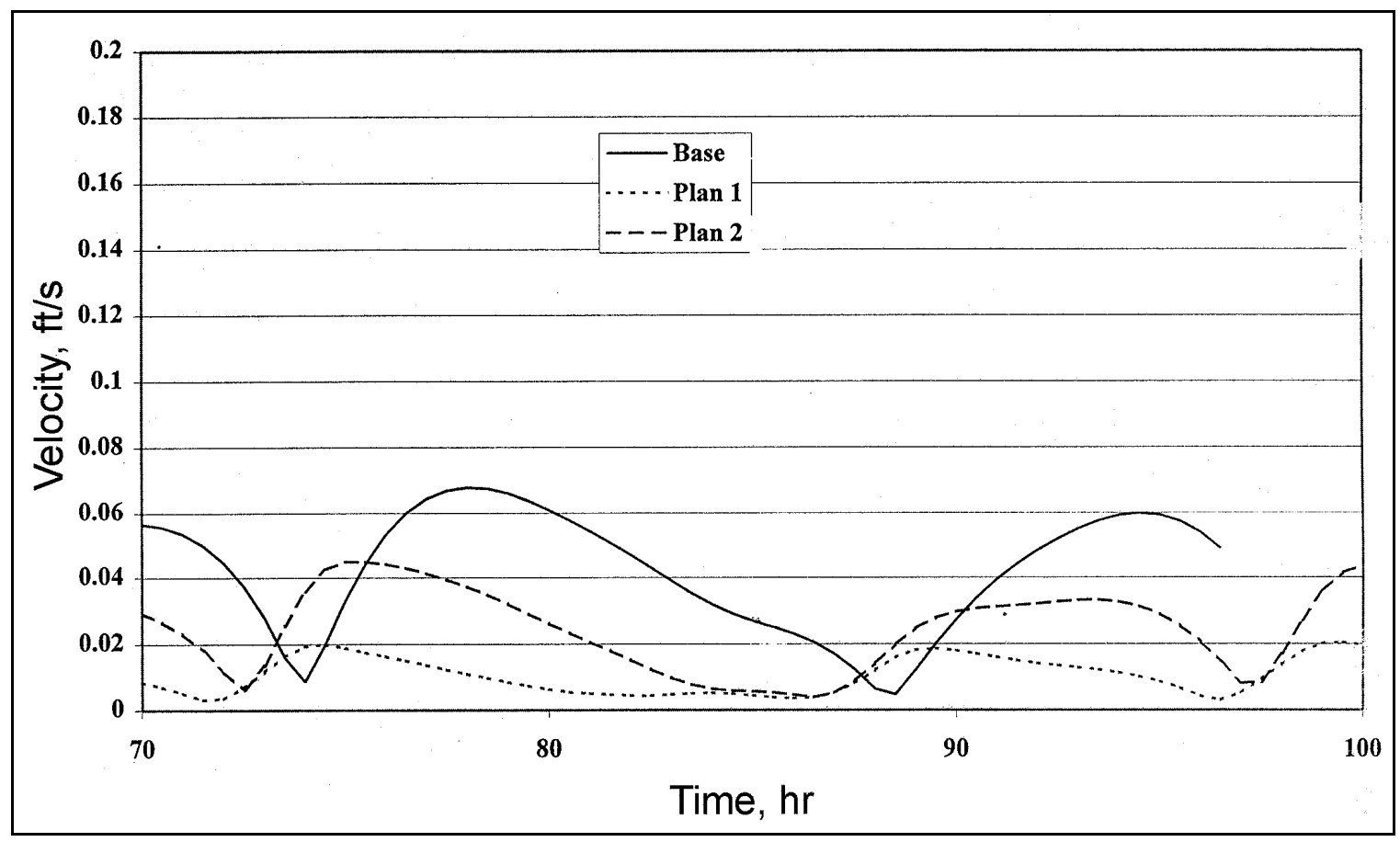

Figure 52. Velocity at station 17 obtained on numerical model

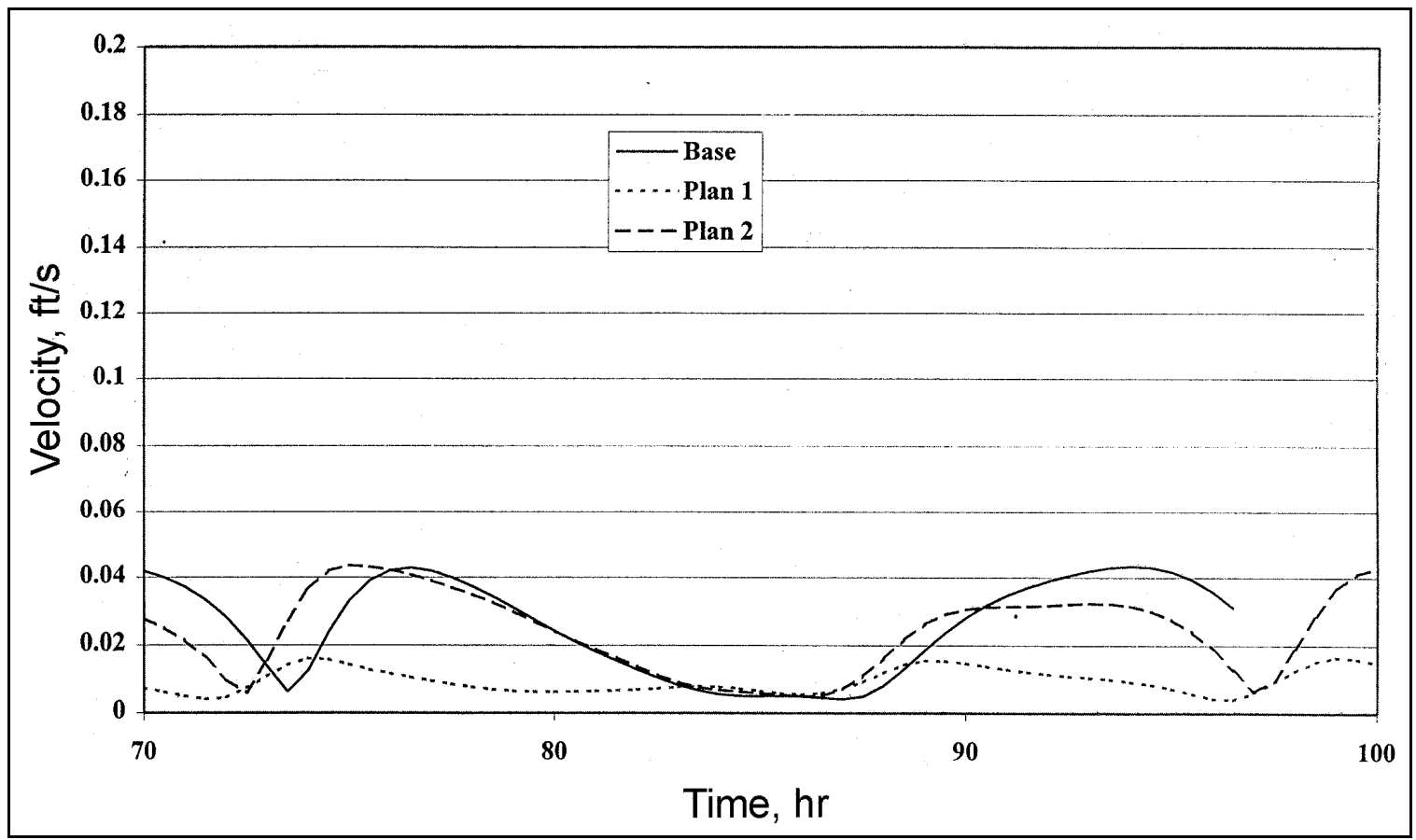

Figure 53. Velocity at station 18 obtained on numerical model 


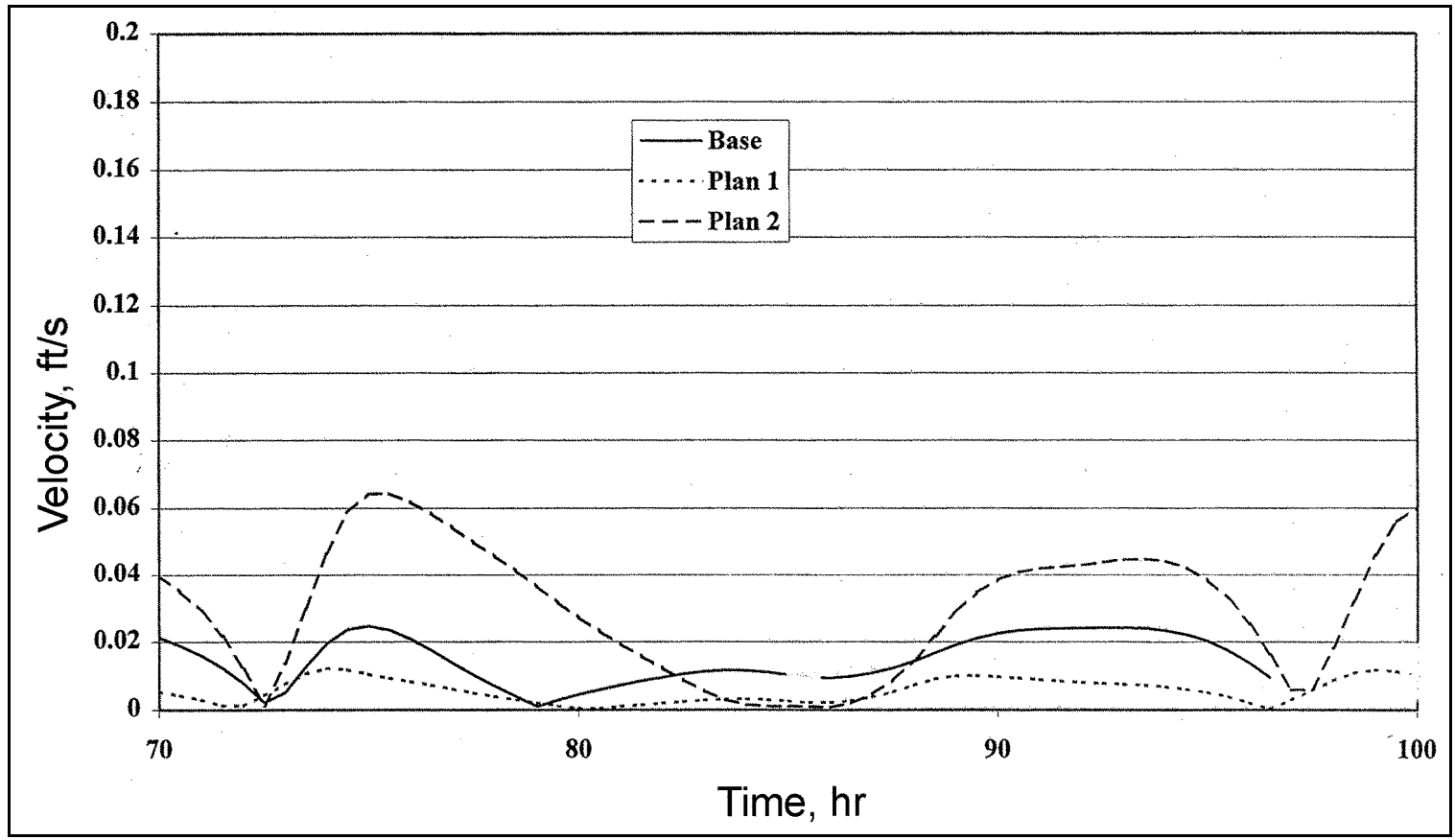

Figure 54. Velocity at station 19 obtained on numerical model

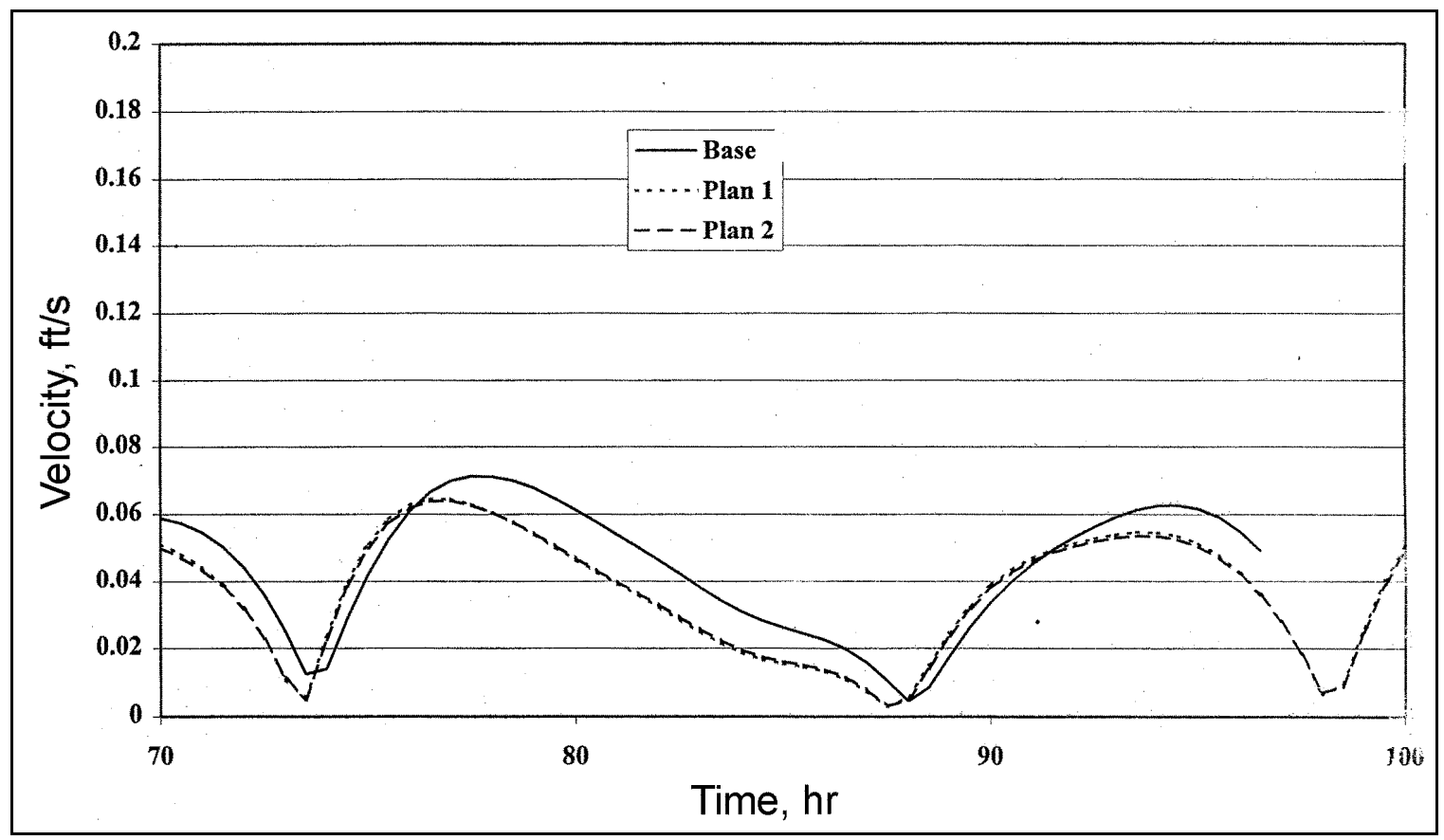

Figure 55. Velocity at station 20 obtained on numerical model 


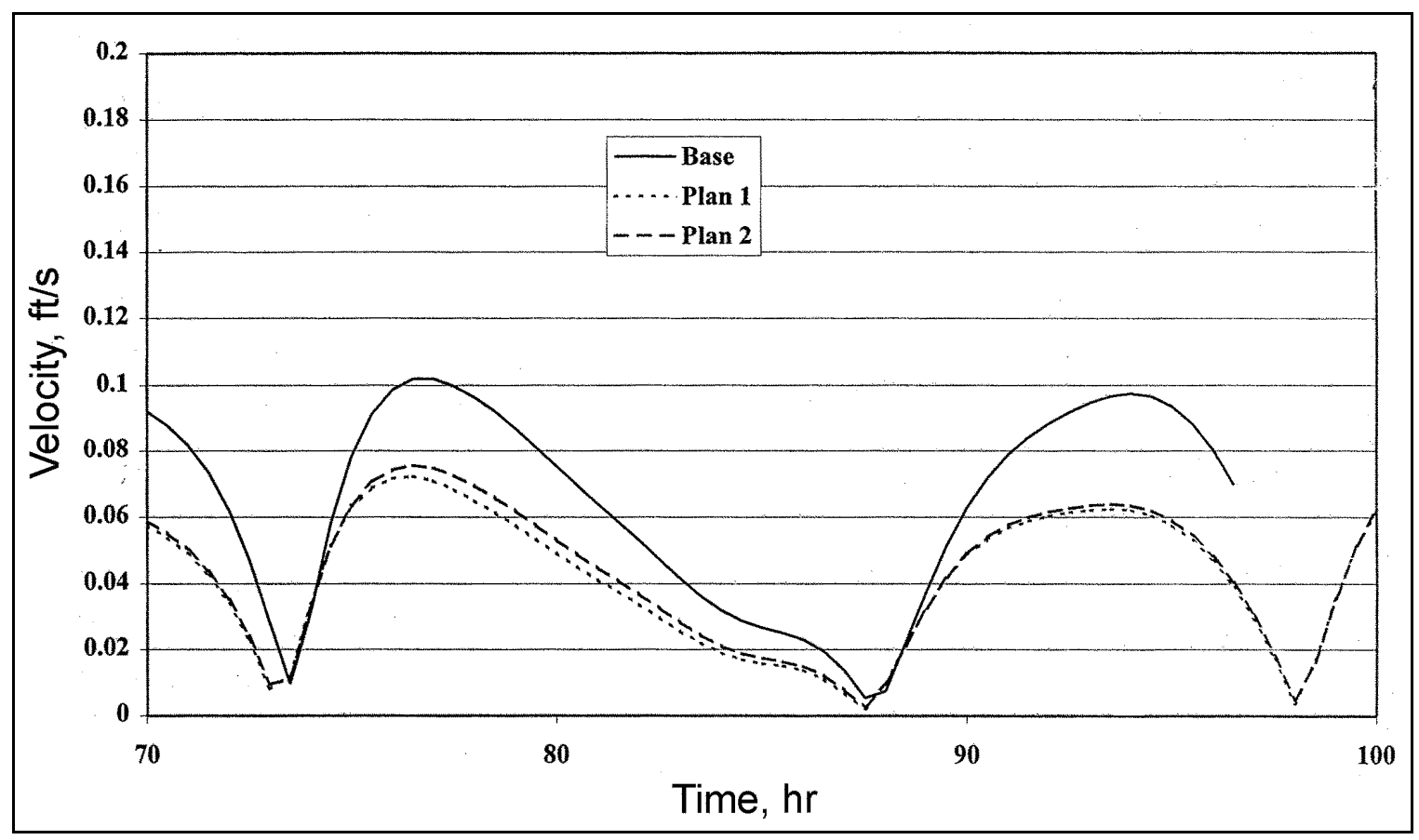

Figure 56. Velocity at station 21 obtained on numerical model

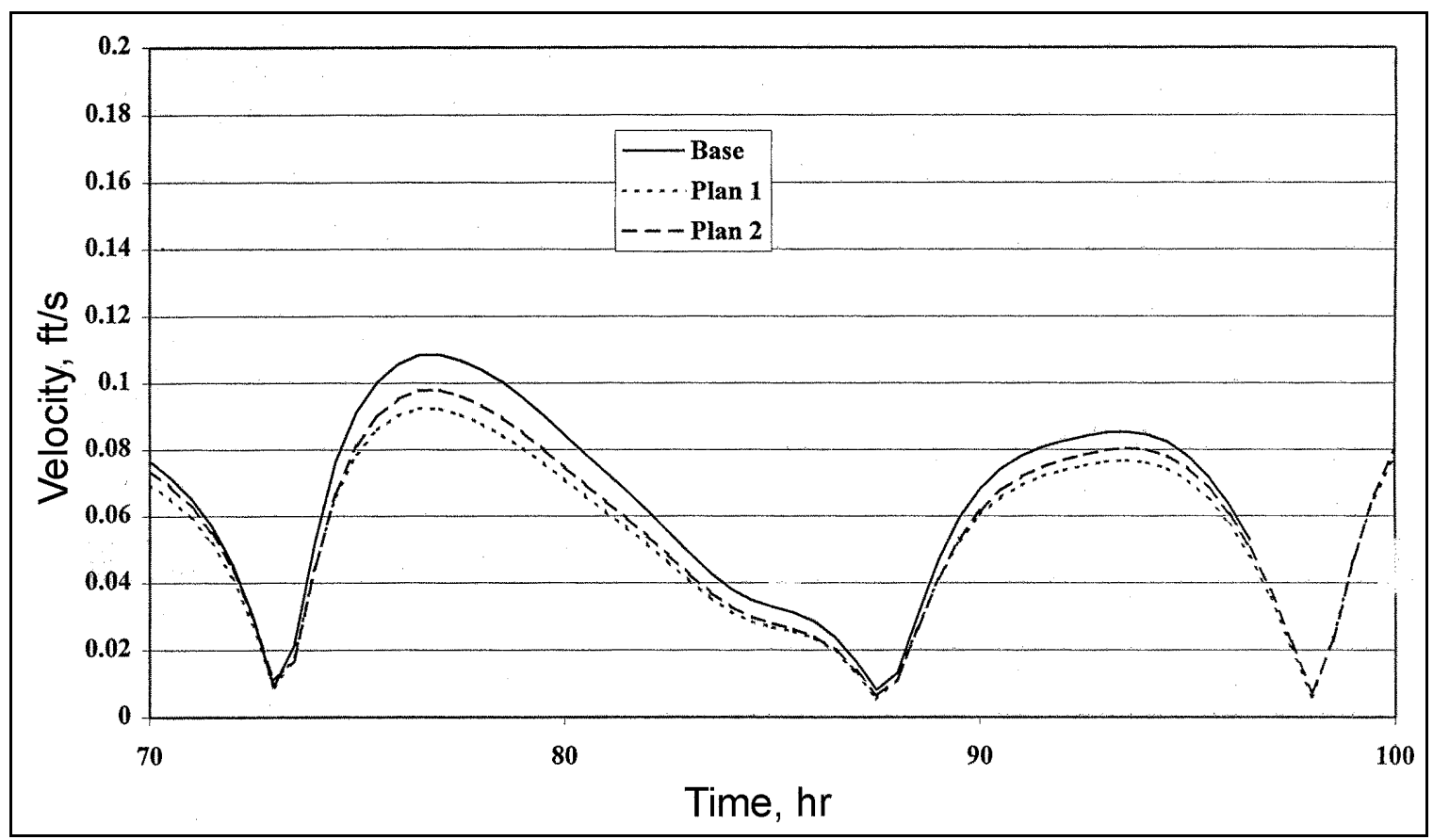

Figure 57. Velocity at station 22 obtained on numerical model 


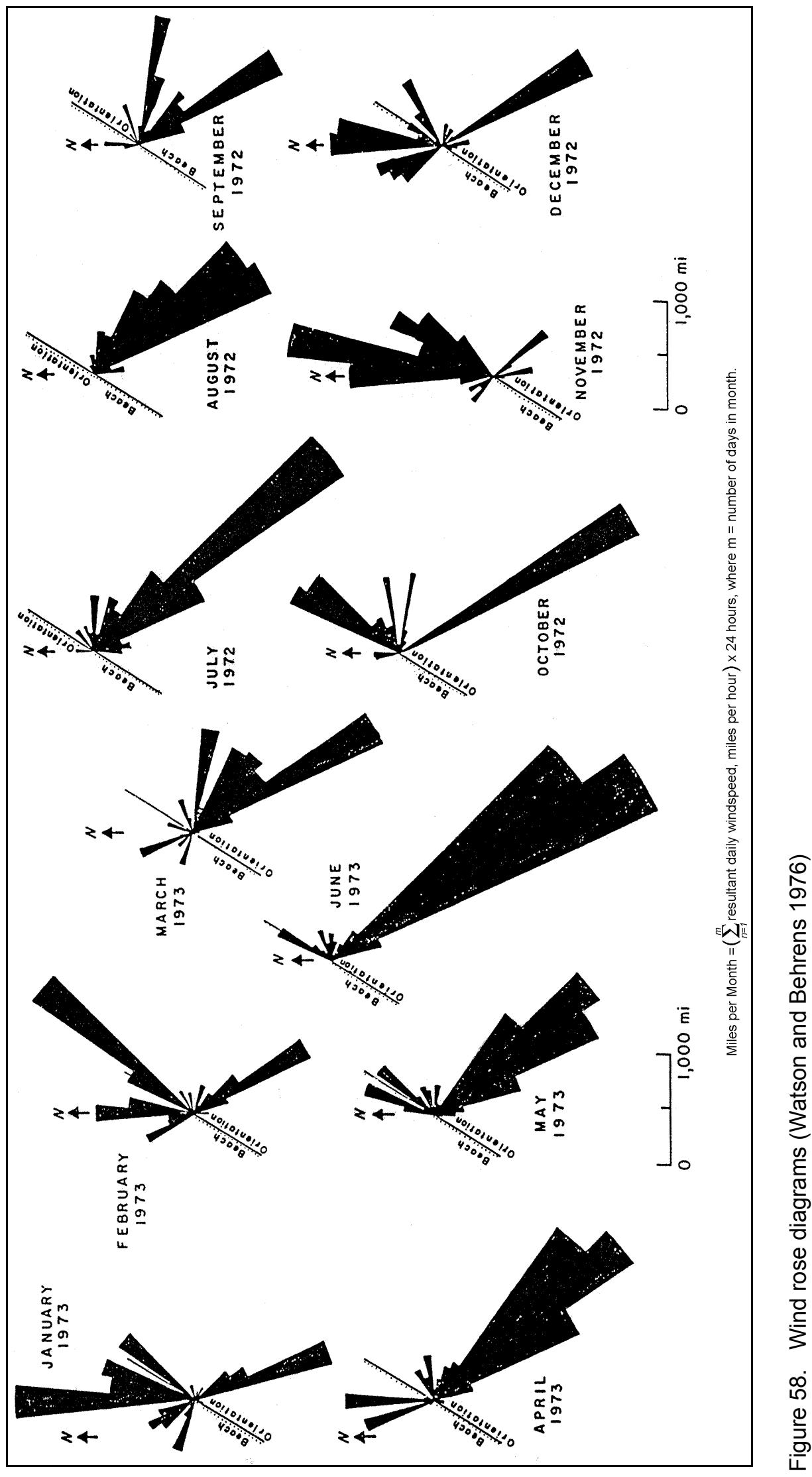




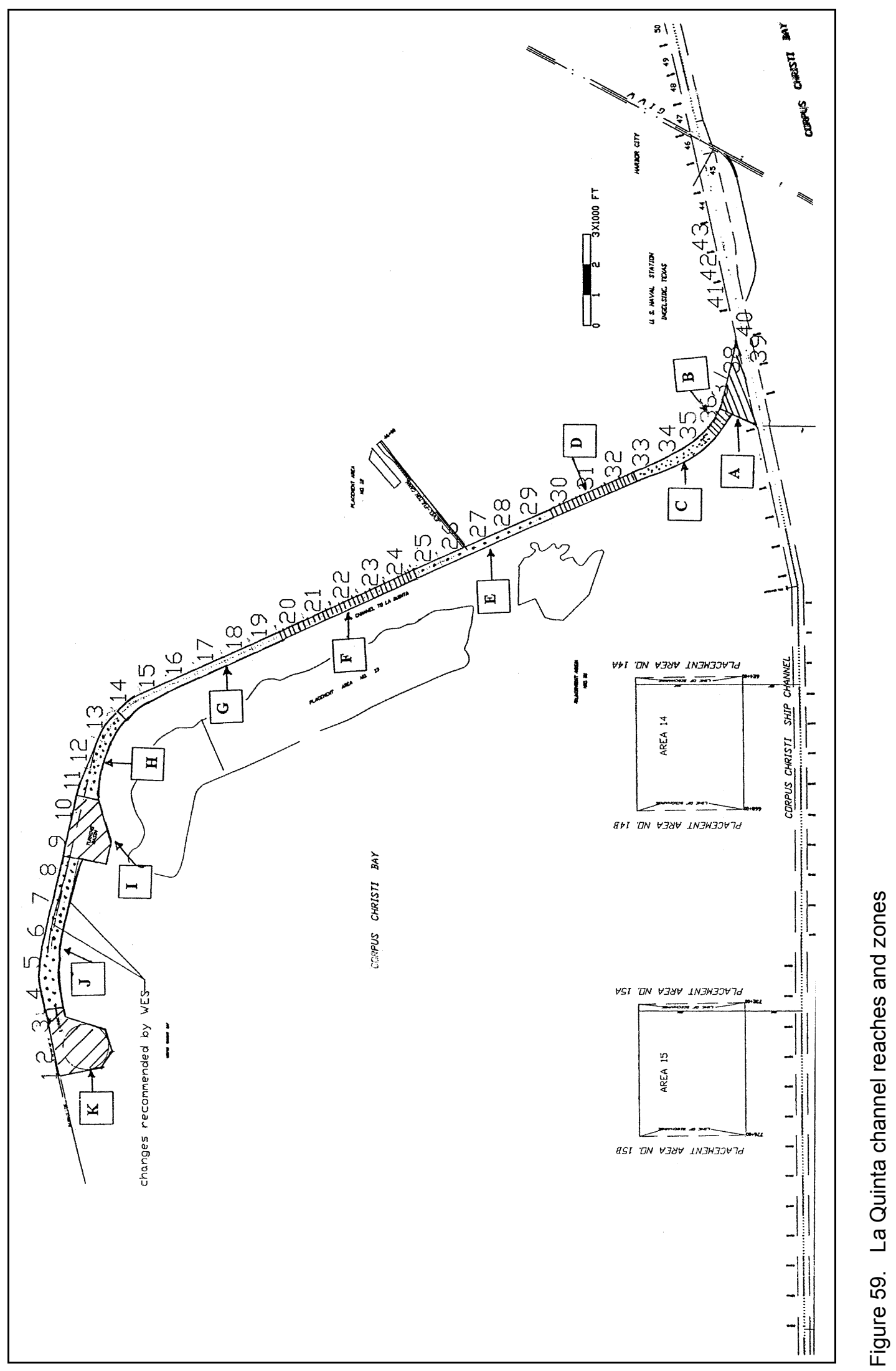




\section{References}

DuBoys, P. (1879). "Le Rhone et les Riviers a Lit Affouillable," Annales des Ponts et Chaussees, Series 5, Vol 18, 141-195.

Einstein H. A. (1950). "The bed load function for sediment transportation in open channels," Technical Bulletin 1026, U.S. Department of Agriculture, Soil Conservation Service, Washington DC.

Parchure T. M., Sarruff, S., and Brown, B. (2001). "Desktop study for shoaling prediction in Corpus Christi navigation channel," ERDC/CHL TR-01-30, U.S. Army Engineer Research and Development Center, Vicksburg, MS.

Shore Protection Manual. (1984). Coastal Engineering Research Center, U.S. Army Corps of Engineers, Washington, DC.

Spaulding, M. L., and Blumberg, A. F., ed. (1997). Proceedings of Fifth International Conference on Estuarine and Coastal Modeling, ASCE. Alexandria, VA.

Watson R. L., and Behrens, W. W. (1976). "Hydraulics and dynamics of new Corpus Christi Pass, Texas: A case history, 1973-75," report prepared for Coastal Engineering Research Center, U.S. Army Corps of Engineers, by University of Texas Marine Sciences Institute, Port Aransas, and Texas A\&M University, College Station, TX. 


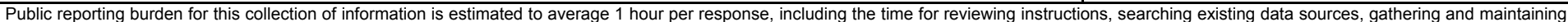

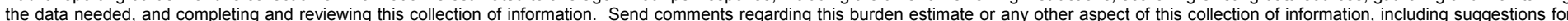

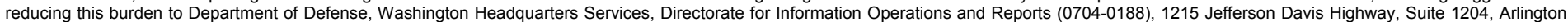

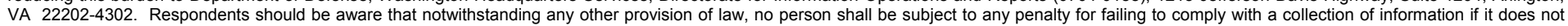
display a currently valid OMB control number. PLEASE DO NOT RETURN YOUR FORM TO THE ABOVE ADDRESS.
1. REPORT DATE (DD-MM-YYYY) 2. REPORT TYPE
September 2002 Final report

\section{TITLE AND SUBTITLE}

Desktop Study for La Quinta Project; Shoaling Prediction in La Quinta Navigation

Channel and Effect of a Barrier in Siltation in Extended La Quinta Channel

3. DATES COVERED (From - To)

5a. CONTRACT NUMBER

5b. GRANT NUMBER

5c. PROGRAM ELEMENT NUMBER

\section{AUTHOR(S)}

Trimbak M. Parchure, Soraya Sarruff, Ben Brown

\section{PERFORMING ORGANIZATION NAME(S) AND ADDRESS(ES)}

U.S. Army Engineer Research and Development Center

Coastal and Hydraulics Laboratory

3909 Halls Ferry Road

Vicksburg, MS 39180-6199

9. SPONSORING / MONITORING AGENCY NAME(S) AND ADDRESS(ES)

U.S. Army Engineer District, Galveston

Galveston, TX 77553-1229

\section{5d. PROJECT NUMBER}

5e. TASK NUMBER

5f. WORK UNIT NUMBER

8. PERFORMING ORGANIZATION REPORT NUMBER

ERDC/CHL TR-02-19

10. SPONSOR/MONITOR'S ACRONYM(S)

11. SPONSOR/MONITOR'S REPORT NUMBER(S)

\section{DISTRIBUTION / AVAILABILITY STATEMENT}

Approved for public release; distribution is unlimited.

13. SUPPLEMENTARY NOTES

\section{ABSTRACT}

The U.S. Army Engineer District, Galveston, proposed two modifications of the La Quinta navigation channel: (1) extension of the navigation channel and providing a new turning basin at the end of the extension, both having the same depth as that of the present navigation channel, namely $13.7 \mathrm{~m}(45 \mathrm{ft})$, and (2) constructing a barrier on the south side of the extended channel. The District requested the Coastal and Hydraulics Laboratory (CHL) of the U.S. Army Engineer Research and Development Center (ERDC), Vicksburg, MS, conduct a desktop study for estimation of future shoaling in the navigation channel with these two modifications. The results of a desktop study are given in this report in two parts for the above two problems.

\section{Shoaling Prediction in La Quinta Navigation Channel}

The approach consisted of the following steps. Field data already available as well as those collected by CHL were analyzed and the results of analysis used. Assumptions were made on the spatial and temporal variation in the values of relevant parameters. Runs were conducted on the existing numerical hydrodynamic model for a few selected conditions to determine the effect of channel extension on the currents in the area of interest. A quantitative estimate was provided on future shoaling in the navigation channel based on the field and model data analysis. The following conclusions were drawn.

a. Proposed extension of La Quinta navigation channel and provision of a new turning basin will cause an increase in the present tidal currents. This is expected to increase the inflow of sediment in the channel, which would result in increased shoaling.

(Continued)

\section{SUBJECT TERMS}

Corpus Christi

Desktop study

Dredging
La Quinta

Navigation channel

Sediment barrier

\section{SECURITY CLASSIFICATION OF:}

\section{a. REPORT}

UNCLASSIFIED b. ABSTRACT

UNCLASSIFIED c. THIS PAGE

UNCLASSIFIED

\section{LIMITATION} OF ABSTRACT
Shoaling

Siltation

\begin{tabular}{c|l}
$\begin{array}{c}\text { 18. NUMBER } \\
\text { OF PAGES }\end{array}$ & $\begin{array}{l}\text { 19a. NAME OF RESPONSIBLE } \\
\text { PERSON }\end{array}$ \\
\cline { 2 - 2 } 79 & $\begin{array}{l}\text { 19b. TELEPHONE NUMBER (include } \\
\text { area code) }\end{array}$ \\
\end{tabular}




\section{ABSTRACT (Concluded)}

b. Bed sediment in the La Quinta channel consists of mostly fine sediment in the category of silt and clay. This suggests that the major process of shoaling consists of deposition of suspended sediment.

c. The area of channel extension and new turning basin has currents across the channel alignment. This increases the probability of deposition of suspended sediment in the area. The new turning basin is larger than the existing basin and the extended channel is wider than the existing channel. These factors contribute to the higher siltation in these reaches.

d. The estimated dredging quantities based on several considerations are given below.

\begin{tabular}{||l|l|l||}
\hline & Present Dredging & $\begin{array}{l}\text { Estimated Dredging After Channel } \\
\text { Extension and New Turning Basin }\end{array}$ \\
\hline \hline Existing channel & $371,064 \mathrm{cu} \mathrm{yd} /$ year & $428,000 \mathrm{cu}$ yd/year \\
& $(283,500 \mathrm{cu} \mathrm{m} /$ year $)$ & $(327,000 \mathrm{cu} \mathrm{m} /$ year \\
\hline With channel extension & - & $222,000 \mathrm{cu}$ yd/year \\
and new turning basin & & $(169,600 \mathrm{cu} \mathrm{m} /$ year $)$ \\
\hline Total & $371,064 \mathrm{cu} \mathrm{yd} /$ year & $650,000 \mathrm{cu}$ yd/year \\
& $(283,500 \mathrm{cu} \mathrm{m} /$ year & \multicolumn{2}{|l}{} \\
\hline
\end{tabular}

Effect of a Barrier on Siltation in Extended La Quinta Channel

The present navigation channel is confined between land on the east side and islands on the west side for most of its length. The proposed extension will have land on its north; however, there will be no natural protection on the south side. This part would therefore be subjected to shoaling caused by waves and currents. Hence, a barrier is proposed to be provided on the south side for providing protection against waves and for arresting sediment transport. The approach for solving this problem was the same as that described above. The conclusions of the study are given below.

a. Proposed 2,380-m- (7,800-ft-) long barrier will provide shelter against waves to the new turning basin area from southeasterly waves, which have a predominant occurrence during a year. The extend of protection will depend mainly on the incident wave direction.

$b$. The proposed barrier will partly arrest wave-induced northerly bed load transport. It also creates stagnant zones on both the north and south sides of the barrier. Over a matter of a few years, the sediment accumulated on the south side of the barrier will travel around the western tip of the barrier, enter on the lee-side, and start depositing because that area does not have adequate energy to move it further on. While some of the bed load may enter the western portion of the new turning basin, the eastern half of the basin and the extended ship channel are not expected to be affected for the reason that this area is energydeficient for bed load transport.

c. The local velocity in the gap between the shoreline and the barrier nearly doubles with the barrier in place. Hence, the amount of wave-induced suspended sediment brought in through the gap is expected to increase compared to the conditions without the barrier.

d. The combined effect is a substantial decrease in bed load sediment and a marginal increase in suspended sediment. The net effect is estimated to result in the following annual dredging quantities.

\begin{tabular}{||l|l|l||}
\hline Zone & Without Barrier & With Barrier \\
\hline \hline New turning basin & $127,000 \mathrm{cu}$ yd/year & $112,000 \mathrm{cu}$ yd/year \\
& $(97,030 \mathrm{cu} \mathrm{m} /$ year $)$ & $(85,570 \mathrm{cu} \mathrm{m}$ year $)$ \\
\hline Extended channel & $95,000 \mathrm{cu}$ yd/year & $76,000 \mathrm{cu}$ yd/year \\
& $(72,580 \mathrm{cu} \mathrm{m} /$ year $)$ & $(58,060 \mathrm{cu} \mathrm{m} /$ year $)$ \\
\hline Total & $222,000 \mathrm{cu} \mathrm{yd} /$ year & $188,000 \mathrm{cu}$ yd/year \\
& $(169,610 \mathrm{cu} \mathrm{m}$ year $)$ & $(143,630 \mathrm{cu} \mathrm{m} /$ year $)$ \\
\hline
\end{tabular}

e. Since channel extension and provision of a new turning basin are entirely new construction, they will result in a substantial change in local water depths, which is expected to severely impact submerged bottom slopes. Local sloughing and slope adjustment to a regime may take a few years, during which the sedimentation in the new construction could be due to reasons other than those taken into consideration for the present study. 